University of Louisville

ThinkIR: The University of Louisville's Institutional Repository

Electronic Theses and Dissertations

$12-2011$

\title{
Thermolysis stability, solution reactivity and structural studies of a thioperoxide-bridged dimolybdenum(V) dimer.
}

Ackim Maduvu

University of Louisville

Follow this and additional works at: https://ir.library.louisville.edu/etd

\section{Recommended Citation}

Maduvu, Ackim, "Thermolysis stability, solution reactivity and structural studies of a thioperoxide-bridged dimolybdenum(V) dimer." (2011). Electronic Theses and Dissertations. Paper 882.

https://doi.org/10.18297/etd/882

This Master's Thesis is brought to you for free and open access by ThinkIR: The University of Louisville's Institutional Repository. It has been accepted for inclusion in Electronic Theses and Dissertations by an authorized administrator of ThinkIR: The University of Louisville's Institutional Repository. This title appears here courtesy of the author, who has retained all other copyrights. For more information, please contact thinkir@louisville.edu. 
THERMOLYSIS STABILITY, SOLUTION REACTIVITY AND STRUCTURAL STUDIES OF A THIOPEROXIDE-BRIDGED DIMOLYBDENUM (V) DIMER.

\author{
By
}

Ackim Maduvu

BSc (HONORS) Applied Chemistry, National University of Science and Technology (NUST), Bulawayo, Zimbabwe, 2004

\author{
A Thesis \\ Submitted to the Faculty of the \\ Graduate School of the University of Louisville \\ In Partial Fulfillment of the Requirements \\ For the Degree of
}

\author{
Master of Science of Chemistry \\ University of Louisville \\ Louisville, Kentucky, U.S.A
}

December 2011 
Copyright 2010 by Department of Chemistry

\author{
All rights reserved
}


THERMOLYSIS STABLITY, SOLUTION REACTIVITY, AND STRUCTURAL STUDIES OF A THIOPEROXIDE-BRIDGED DIMOLYBDENUM(V) DIMER.

$$
\text { By }
$$

$$
\text { Ackim Madhuvu }
$$

BSc (HONORS), National University of Science and Technology (NUST), Zimbabwe, 2004

August 16, 2010

By the following Thesis Committee:

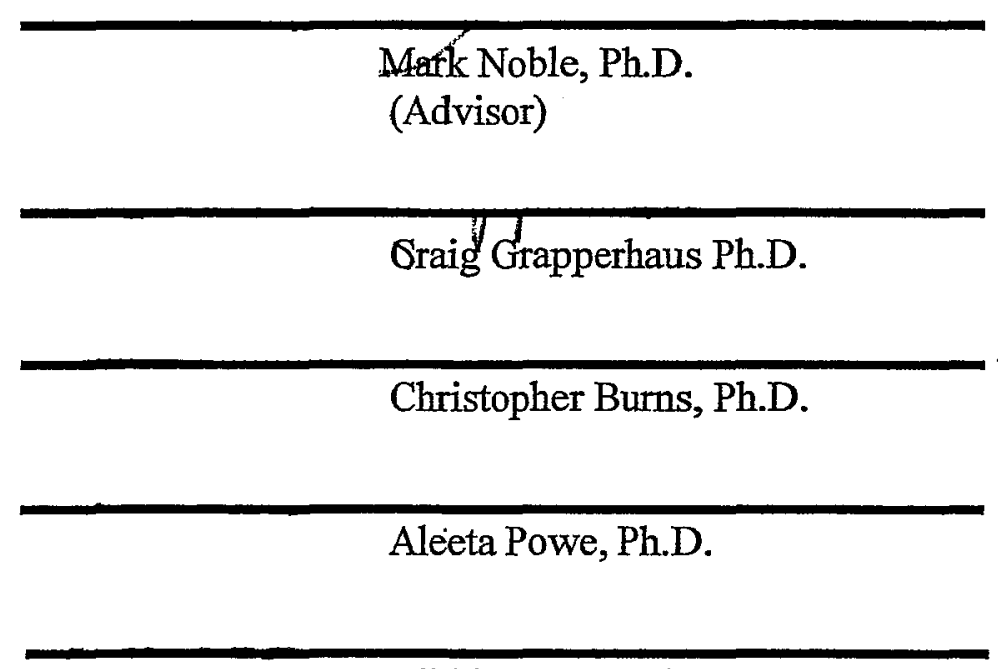

Nikki Kunene, Ph.D. 


\section{DEDICATION}

This thesis is dedicated to my family, relatives and friends for their unwavering support, encouragement and patience. I also appreciate the support I received from the people of . Gokomere mission where I spend most of child hood life. Friends and Family "This is it". 


\section{ACKNOWLEDGEMENTS}

I would like to thank my mentor, Dr. Mark E. Noble for his patience, guidance and support. I would also like to thank my committee members, Drs. Craig A. Grapperhaus, Christopher T. Burns, Aleeta M. Powe and Nikki Kunene. Additionally I extend my appreciation to Dr Neal Stolowich, Dr Mark Mashuta and the Chemistry Department of the University of Louisville at large. 


\title{
ABSTRACT \\ . THERMOLYSIS STABILITY, REACTTVITY, AND STRUCTURAL STUDY OF A THIOPEROXIDE-BRIDGED DIMOLYBDENUM(V) DIMER
}

\author{
Ackim Madhuvu
}

August 16, 2010

Molybdenum-sulfur complexes have developed a lot of interest in the chemistry of metal-coordinated sulfur due to their importance in biological systems and in industrial processes like catalysis. For example, in biological processes molybdenum has been recognized as a very important metal in enzymes used for nitrogen fixation for over 60 years.

In this dissertation, the system of the imidodithiophosphate $\mu$-carboxylatomolybdenum(V) dimer was studied for crystal thermolytic stability and solution reactivity. $\mathrm{Mo}_{2}(\mathrm{NTo})_{2}\left(\mathrm{~S}_{2} \mathrm{P}(\mathrm{OEt})_{2}\right)_{2}\left(\mu-\mathrm{O}_{2} \mathrm{CR}\right)(\mu-\mathrm{SBn})(\mu-\mathrm{SO})$ will be abbreviated as $\mathrm{BnS}\left\{\mathrm{Mo}_{2}\right\} \mathrm{SO}$, where $\mathrm{R}$ is $\mathrm{CH}_{3}, \mathrm{CH}_{2} \mathrm{CH}_{2} \mathrm{CH}_{3}, \mathrm{C}\left(\mathrm{CH}_{3}\right)_{3}$ or $\mathrm{CH}\left(\mathrm{OCH}_{3}\right) \mathrm{C}_{6} \mathrm{H}_{5}$. In the crystal phase, the packing of $\mathrm{BnS}\left\{\mathrm{Mo}_{2}\right\} \mathrm{SO}$ acetate allows the molecule to pair off on a close approach to allow nucleophilic attack on each other. The attack is reciprocal for each of the molecules in a pair. It is because of this juxtaposition, coupled with the inherent nucleophilic behavior of the $\mathrm{S}(\mathrm{O})$, which provides the solid state reaction at high temperatures.

In solution reactions, the nucleophilic behavior of the (S)O in $\mathrm{BnS}\left\{\mathrm{Mo}_{2}\right\} \mathrm{SO}$ with $\mathrm{BnBr}$ leads to the formation of the cation, $\left[\mathrm{BnS}\left\{\mathrm{Mo}_{2}\right\} \mathrm{SOBn}\right]^{+}$, which undergoes either de-benzylation to give $\left[\mathrm{Mo}_{2}(\mathrm{NTo})_{2}\left(\mathrm{~S}_{2} \mathrm{P}(\mathrm{OEt})_{2}\right)_{2}\left(\mu-\mathrm{O}_{2} \mathrm{CMe}\right)(\mu-\mathrm{S})(\mu-\mathrm{SOBn})\right]$, or deesterification to give $\left[\mathrm{Mo}_{2}(\mathrm{NTo})_{2}\left(\mathrm{~S}_{2} \mathrm{P}=\mathrm{O}(\mathrm{OEt})\right)\left(\mathrm{S}_{2} \mathrm{P}(\mathrm{OEt})_{2}\left(\mu-\mathrm{O}_{2} \mathrm{CMe}\right)(\mu-\mathrm{SBn})(\mu-\mathrm{SOBn})\right]\right.$ 
This was a one pot synthesis of $\mathrm{S}\left\{\mathrm{Mo}_{2}\right\} \mathrm{SOBn}$ unlike in the synthesis of $\mathrm{S}\left\{\mathrm{Mo}_{2}\right\} \mathrm{SOEt}$ or $\mathrm{S}\left\{\mathrm{Mo}_{2}\right\} \mathrm{SOMe}$ which was a two pot process. 


\section{TABLE OF CONTENTS}

\section{PAGE}

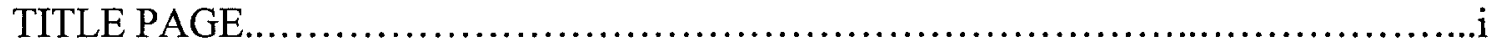

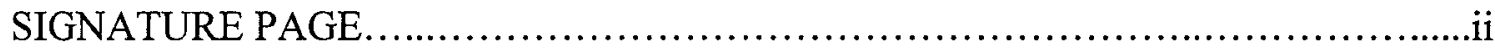

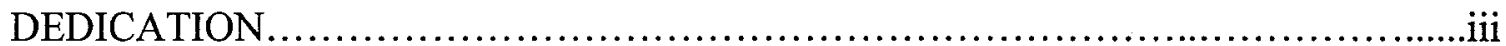

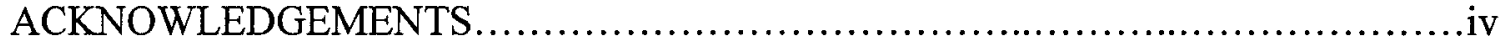

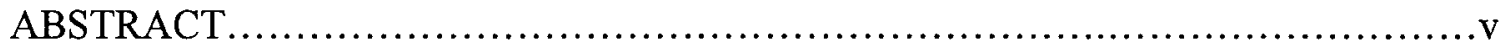

LIST OF TABLES .....................................................................

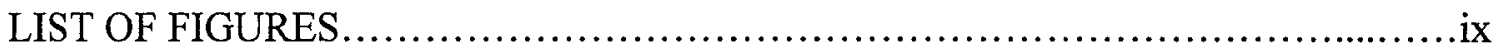

CHAPTER ONE INTRODUCTION.............................................

CHAPTER TWO DECOMPOSITION STUDIES OF SO BRIDGED

DIMOLYBDENUM(V) DIMER $\left[\mathrm{Mo}_{2}(\mathrm{NTo})_{2}\left(\mathrm{~S}_{2} \mathrm{P}(\mathrm{OEt})_{2}\right)_{2}(\mu-\right.$

$\left.\left.\mathrm{O}_{2} \mathrm{CR}\right)(\mu-\mathrm{SBn})(\mu-\mathrm{SO})\right], \mathrm{BnS}\left\{\mathrm{Mo}_{2}\right\} \mathrm{SO} \ldots \ldots \ldots \ldots \ldots \ldots \ldots \ldots . \ldots \ldots$

CHAPTER THREE SYNTHESIS OF BENZYL THIOPEROXIDE BRIDGED MOLYBDENUM(V) DIMER $\left[\mathrm{Mo}_{2}(\mathrm{NTO})_{2}\left(\mathrm{~S}_{2} \mathrm{P}(\mathrm{OEt})_{2}\right)_{2}(\mu-\right.$

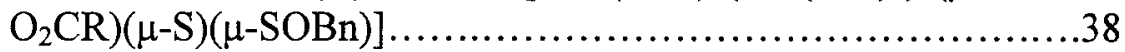

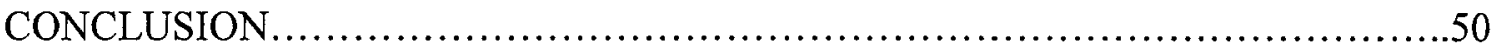

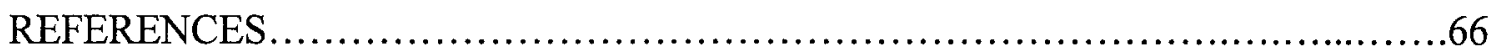

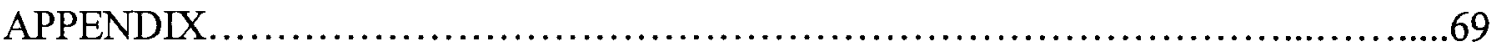

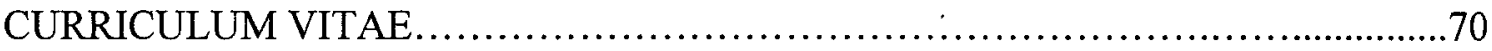




\section{LIST OF TABLES}

TABLE

PAGE

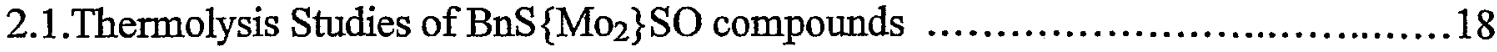

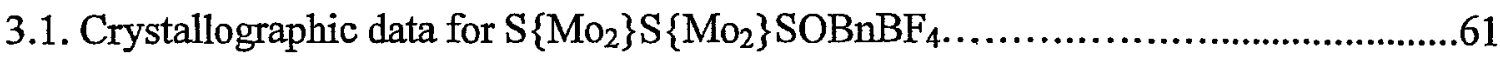

3.2. Selected Positional Parameters for $\left[\mathrm{S}\left\{\mathrm{Mo}_{2}\right\} \mathrm{SS}\left\{\mathrm{Mo}_{2}\right\} \mathrm{SOBn}\right]^{+} \ldots \ldots \ldots \ldots \ldots \ldots \ldots . . . . . .62$

3.3. Selected Bond Angles (deg) for $\mathrm{S}\left\{\mathrm{Mo}_{2}\right\} \mathrm{SS}\left\{\mathrm{Mo}_{2}\right\} \mathrm{SOBn}^{+}$and $\mathrm{BnS}\left\{\mathrm{Mo}_{2}\right\} \mathrm{SOEt}^{+} \ldots . .63$

3.4. Selected Bond Angles (deg) for $\mathrm{S}\left\{\mathrm{Mo}_{2}\right\} \mathrm{SS}\left\{\mathrm{Mo}_{2}\right\} \mathrm{SOBn}^{+}$and $\mathrm{S}\left\{\mathrm{Mo}_{2}\right\} \mathrm{SS}\left\{\mathrm{Mo}_{2}\right\} \mathrm{S} . .64$

3.5. Selected Bond length $(\AA)$ for $\mathrm{S}\left\{\mathrm{Mo}_{2}\right\} \mathrm{SS}\left\{\mathrm{Mo}_{2}\right\} \mathrm{SOBn}^{+}$and $\mathrm{BnS}\left\{\mathrm{Mo}_{2}\right\} \mathrm{SOEt}^{+} \ldots \ldots .65$

3.6. Selected Bond length $(\AA)$ for $\mathrm{S}\left\{\mathrm{Mo}_{2}\right\} \mathrm{SS}\left\{\mathrm{Mo}_{2}\right\} \mathrm{SOBnBF}_{4}$ and $\mathrm{S}\left\{\mathrm{Mo}_{2}\right\} \mathrm{SS}\left\{\mathrm{Mo}_{2}\right\} \mathrm{S} .66$ 


\section{LIST OF FIGURES}

FIGURE

PAGE

1.1. Molybdenum(V) dimer core representation using stick diagram.......................4

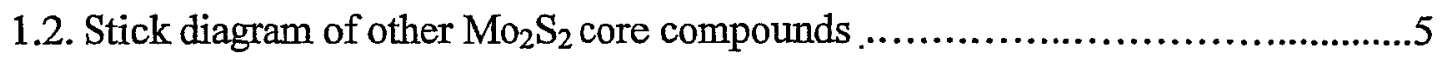

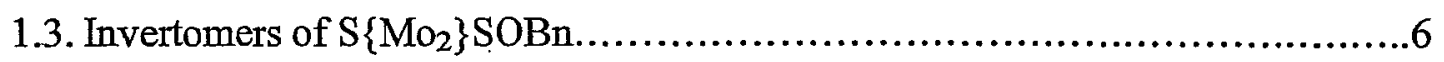

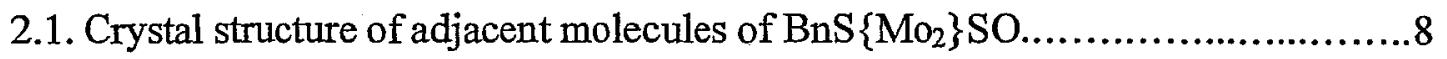

2.2. ${ }^{1} \mathrm{H}$ spectrum of $\mathrm{BnS}\left\{\mathrm{Mo}_{2}\right\}$ SO pivalate..........................................20

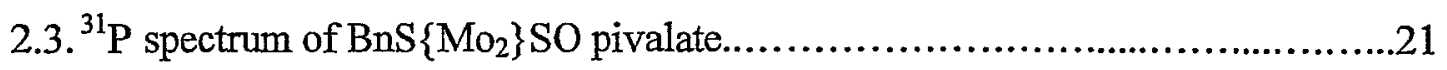

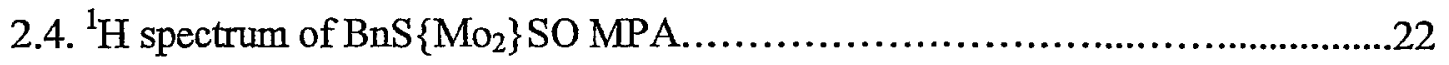

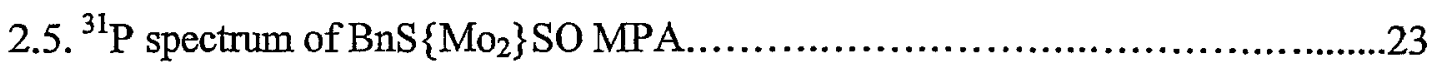

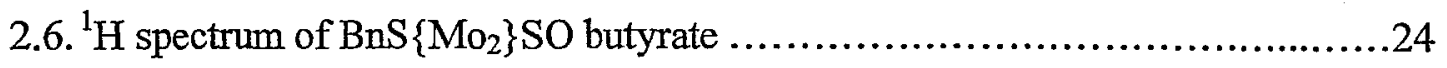

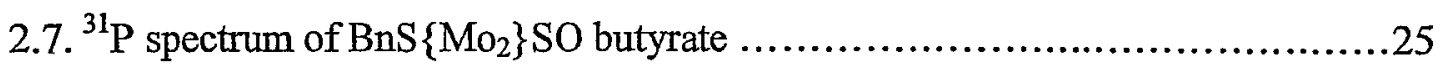

2.8. ${ }^{31} \mathrm{P}$ spectrum of $\mathrm{BnS}\left\{\mathrm{Mo}_{2}\right\} \mathrm{SO}$ pivalate after two hrs of photolysis.................26

2.9. ${ }^{31} \mathrm{P}$ spectrum of $\mathrm{BnS}\left\{\mathrm{Mo}_{2}\right\}$ SO pivalate after eight hrs of photolysis...............27

2.10. ${ }^{31} \mathrm{P}$ spectrum of $\mathrm{BnS}\left\{\mathrm{Mo}_{2}\right\}$ SO butyrate after two hrs of photolysis...............28

2.11. ${ }^{31} \mathrm{P}$ spectrum of $\mathrm{BnS}\left\{\mathrm{Mo}_{2}\right\}$ SO butyrate after eight hrs of photolysis.............29

2.12. ${ }^{31} \mathrm{P}$ spectrum of $\mathrm{MeS}\left\{\mathrm{Mo}_{2}\right\} \mathrm{SO}$ acetate after two hrs of photolysis................30

2.13. ${ }^{31} \mathrm{P}$ spectra of $\mathrm{MeS}\left\{\mathrm{Mo}_{2}\right\} \mathrm{SO}$ acetate after eight hrs of photolysis..................31

2.14. ${ }^{31} \mathrm{P}$ spectrum of $\mathrm{BnS}\left\{\mathrm{MO}_{2}\right\} \mathrm{SO}$ acetate after two hrs of photolysis................32

2.15. ${ }^{31} \mathrm{P}$ spectrum of $\mathrm{BnS}\left\{\mathrm{Mo}_{2}\right\} \mathrm{SO}$ acetate after eight hrs of photolysis ..............33

2.16. ${ }^{31} \mathrm{P}$ spectrum of $\mathrm{BnS}\left\{\mathrm{Mo}_{2}\right\}$ SO MPA after two hrs of photolysis...................34 
217. ${ }^{31} \mathrm{P}$ spectrum of $\mathrm{BnS}\left\{\mathrm{Mo}_{2}\right\}$ SO MPA after eight hrs of hotolysis..................35

2.18. ${ }^{1} \mathrm{H}$ spectrum of $\mathrm{BnS}\left\{\mathrm{Mo}_{2}\right\}$ SO MPA after two hrs of thermolysis at $100^{\circ} \ldots \ldots .36$

2.19. ${ }^{31} \mathrm{P}$ spectrum of $\mathrm{BnS}\left\{\mathrm{Mo}_{2}\right\} \mathrm{SO} \mathrm{MPA}$ after $2 \mathrm{hrs}$ of thermolysis at $100^{\circ} \ldots \ldots . . .37$

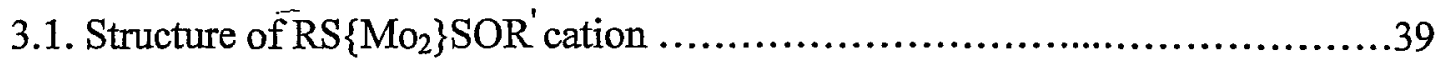

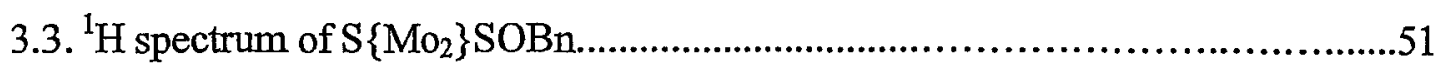

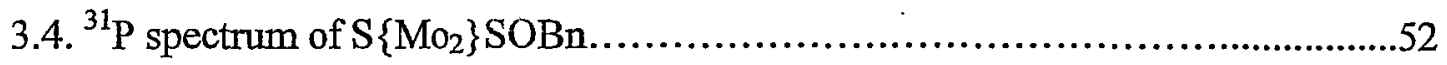

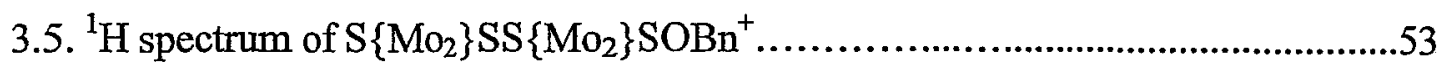

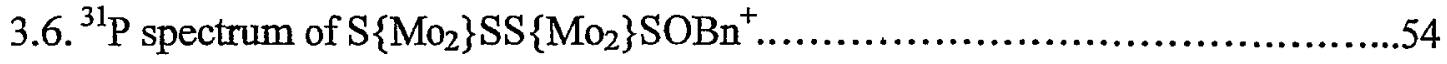

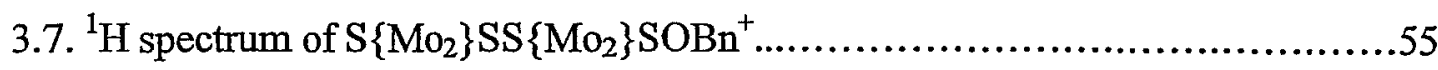

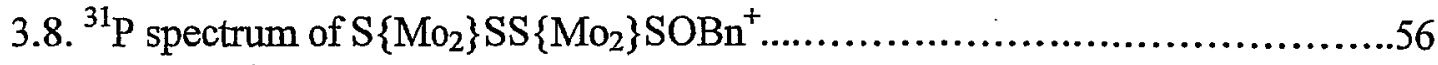

3.9. ${ }^{31} \mathrm{P}$ spectrum taken during the reaction of $\mathrm{BnS}\left\{\mathrm{Mo}_{2}\right\} \mathrm{SO}$ and $\mathrm{BnBr}$..................57

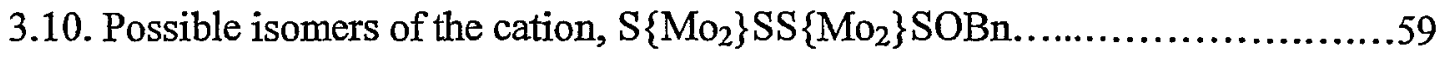




\section{LIST OF SCHEMES}

SCHEME

PAGE

3.1. Proposed mechanism of $\mathrm{S}\left\{\mathrm{Mo}_{2}\right\} \mathrm{SOBn}$ formation.................................................

3.2. Proposed mechanism of $\left[\mathrm{S}\left\{\mathrm{MO}_{2}\right\} \mathrm{SS}\left\{\mathrm{Mo}_{2}\right\} \mathrm{SOBn}\right]^{+}$formation......................46

3.3. Proposed mechanism of $\left[\mathrm{S}\left\{\mathrm{Mo}_{2}\right\} \mathrm{SS}\left\{\mathrm{Mo}_{2}\right\} \mathrm{SOBn}\right]^{+}$radical reactions................58 


\section{CHAPTER ONE}

\section{INTRODUCTION}

Molybdenum-sulfur complexes are considered one of the most important metalsulfur systems. In nature, sulfur has a wide and extensive range of applications in biological, atmospheric, geochemical and cosmochemical processes in addition to human and industrial processes. ${ }^{1,2}$

A variety of metallosulfur complexes have shown much sulfur centered reactivity and several systems have been developed. Much of the interest from these systems was derived from the pivotal role of metallosulfur systems in a variety of catalytic applications. ${ }^{3}$

For over 60 years in biological processes, for example, molybdenum has been recognized as very important for bacterial nitrogen fixation. ${ }^{4}$ Other metals like tungsten have joined the congener molybdenum as a component of redox enzymes. ${ }^{5,6}$ In all types of molybdenum and tungsten enzymes, the coordination sphere of the group six element contains at least three of the heavier chalcogenide donors although sometimes this includes a lone selenium donor. This presence of two or more sulfur (or sulfur and selenium) atoms in adjacent positions suggests the possibility of ligand redox processes. Such processes are illustrated in molybdenum and tungsten chalcogenide chemistry. ${ }^{1,2,7}$

Ligand redox activity is illustrated by the reaction of $\mathrm{WS}_{4}{ }^{2-}$ with the disulfide of 1,1-dithiolate ligands shown in eq 1.1, while internal redox trends are illustrated by reaction of $\mathrm{MoS}_{4}{ }^{2-}, \mathrm{WSe}_{4}{ }^{2-}, \mathrm{VS}_{4}{ }^{3-}$, or $\mathrm{ReS}_{4}{ }^{-}$with the same disulfide. In both cases $\mathrm{R}=$ small alkyl group, such as ethyl or methyl. 
$\mathrm{W}^{\mathrm{VI} \mathrm{S}_{4}{ }^{2-}}+\mathrm{R}_{2} \mathrm{NC}(\mathrm{S}) \mathrm{S}-\mathrm{SC}(\mathrm{S}) \mathrm{NR}_{2} \rightarrow \mathrm{W}^{\mathrm{V}} \mathrm{S}\left(\eta^{2}-\mathrm{S}_{2}\right)\left(\mathrm{S}_{2} \mathrm{CNR}_{2}\right)_{2}$

The organic disulfide acts as the oxidant, which is reduced to form the two dithiocarbamates that will be coordinated to $\mathrm{W}$ in the product. Two of the sulfido ligands on the metal act as the reducing agents, which are oxidized to give a disulfido $\left(\mathrm{S}_{2}{ }^{2-}\right)$ group that remains coordinated to the metal. The process involves solely ligand redox as the oxidation state of the tungsten does not change at all. Included among these are redox processes that involve as many as six electrons per $\mathrm{W}$, which nevertheless, occurs without oxidation of the metal.

In contrast to the ligand redox reactions, the reaction of tetrathiomolybdate with the same thiuram disulfides, shown in eq 1.2, gives a product in which the Mo is in oxidation state $\mathrm{V}$.

$\mathrm{Mo}^{\mathrm{V}_{\mathrm{S}}} \mathrm{S}_{4}{ }^{2-}+\mathrm{R}_{2} \mathrm{NC}(\mathrm{S}) \mathrm{S}-\mathrm{SC}(\mathrm{S}) \mathrm{NR}_{2} \rightarrow \mathrm{Mo}^{\mathrm{V}}\left(\eta_{2}-\mathrm{S}_{2}\right)\left(\mathrm{S}_{2} \mathrm{CNR}_{2}\right)_{3}$

Under the internal electron transfer, the molybdenum has been reduced by coordinated sulfide, which is oxidized to the disulfide. The remaining redox equivalents necessary to oxidize the sulfur come from the external oxidant, the thiuram disulfide. A key feature of this reaction is the internal electron transfer that occurs between $\mathrm{S}^{2-}$ and the $\mathrm{Mo}(\mathrm{VI})$ ion. A substantial number of ligand redox processes occur in multisulfur molybdenum sites. ${ }^{8}$

Another interesting feature about metallosulfur complex lies in the similarities of organic sulfenate ester counterparts (R'SOR) or of the closely related organic sulfoxides (R'S $(=0) R$ ) and sulfenic acids ( $\left.\mathrm{R}^{\prime} \mathrm{SOH}\right)$. Organic sulfoxides, $\mathrm{R}_{2} \mathrm{~S}=\mathrm{O}$, are among the most numerous compounds which contain the $\mathrm{S}_{1} \mathrm{O}_{1}$ unit. ${ }^{9-11}$ Studies have increased drastically; examples include reduction of metal complexes, oxidation of coordinated sulfur, protonation at coordinated sulfur, S-alkylation and S-deakylation on metal-sulfur complexes. ${ }^{11}$

The R'S-OR sulfenate esters are less common when compared to their isomers, 
the organic sulfoxides, $\mathrm{R}_{2} \mathrm{~S}=\mathrm{O}$, due to their high reactivity. Some metal complexes with molecular sulfenate esters R'SOR, as ligands have been reported. ${ }^{12}$ Among sulfur oxidemetal complexes, the synthesis and reactivity of sulfur dioxide-metal complexes have been most studied. Sulfur dioxide is a remarkable ligand. Its coordination properties are more diverse than any other small molecule. ${ }^{13}$

$$
\left[\operatorname{Ir}\left(\mu^{2}-\mathrm{S}_{2} \mathrm{OMe}\right)(\mathrm{dppe})_{2}\right]^{2+} \text { and }\left[\operatorname{Ir}\left(\mu^{1}-\mathrm{SOMe}\right)(\mathrm{MeNC})(\mathrm{dppe})_{2}\right]^{2+} \text { were some of the }
$$

first transition metal thiosulfinate and sulfenate ester complexes to be discovered by Rauchfuss and co-workers ${ }^{14}$ and they modified the complexes by use of metal ions in future developments of alkyl-O-sulfenic acid derivatives. Since the discovery, metals have been used in the stabilization of species like alkysulfenates. While several dimetal sulfoxide analogs, $\mathrm{M}_{2}(\mu-\mathrm{SO})$, are known, their numbers, along with those of SO-bridged complexes of any nuclearity, $\mathrm{M}_{\mathrm{x}} \mathrm{SO}^{13-19}$, pale in comparison to the number of metal- $\mathrm{SO}_{2}$ complexes whose synthesis and reactivity have been extensively well developed. ${ }^{14,19,20}$

Cysteine sulfenates are common and highly reactive cysteine sulfenate anions actually facilitate the study of nucleophilic reactivities by chelating to the metal. The metal-sulfur chemistry has been used to introduce chirality in the organic sulfoxide molecule. ${ }^{3,23}$

This dissertation deals with some chemistry of the SO functional group in a thioperoxide-bridged molybdenum(V) dimer. ${ }^{21}$ This thesis is based on an $\mathrm{Mo}_{2} \mathrm{~S}_{2}$ core wherein sulfur sites bridge two molybdenums. Additionally, an acetate also bridges while a dithiophosphate and a $p$-tolylimido group bind each molybdenum shown in Figure $1.1 .^{25}$ 


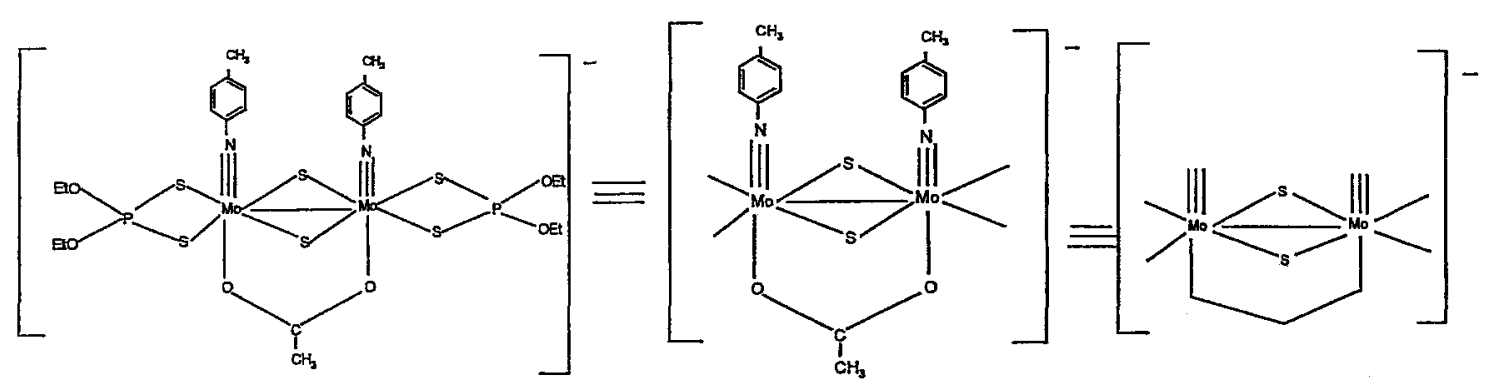

Figure 1.1 The molybdenum(V) dimer core representation using stick diagrams

The art work is simplified by truncation of ancillary ligands to give the simplified stick drawings illustrated in Figure 1.1. This anionic imido-dithiophosphato-carboxylatosulfido-molybdenum(V) dimer, $\left[\mathrm{Mo}_{2}(\mathrm{NTo})_{2}\left(\mathrm{~S}_{2} \mathrm{P}(\mathrm{OEt})_{2}\right)_{2}\left(\mu-\mathrm{O}_{2} \mathrm{CMe}\right)(\mu-\mathrm{S})_{2}\right]^{-}$is designated as $\left[\mathrm{S}\left\{\mathrm{Mo}_{2}\right\} \mathrm{S}\right]^{-}$in this thesis. Other abbreviations in this thesis include: $\mathrm{Bn}=$ Benzyl, MPA $=(\mathrm{R})-(-)-\alpha-$ methoxyphenylacetic acid, $\left[\mathrm{Mo}_{4}\right]=\left[\mathrm{Mo}(\mathrm{NTo})\left(\mathrm{S}_{2} \mathrm{P}(\mathrm{OEt})_{2}\right)(\mu-\mathrm{S})\right]_{4}$ and To $=p$-tolylimido. Other compounds with the $\mathrm{Mo}_{2} \mathrm{~S}_{2}$ core, but with a different kind of carboxylate bridging group, generalized as $\mathrm{Mo}_{2}(\mathrm{NTo})_{2}\left(\mathrm{~S}_{2} \mathrm{P}(\mathrm{OEt})_{2}\right)_{2}\left(\mu-\mathrm{O}_{2} \mathrm{CR}\right)(\mu-\mathrm{SBn})(\mu-$ SO), will be abbreviated as $\mathrm{BnS}\left\{\mathrm{Mo}_{2}\right\} \mathrm{SO}$; this may be followed by the name of the carboxylate bridge, as shown in Figure 1.2. Unless otherwise indicated, the carboxylate bridge is acetate.

The nucleophilic behavior of $\mathrm{BnS}\left\{\mathrm{Mo}_{2}\right\}$ SO leads to O-alkylation and formation of the thioperoxide ligand, ROS. For example, in the case of the $\mathrm{Bn}^{+}$electrophile, the compound formed is $\mathrm{Mo}_{2}(\mathrm{NTo})_{2}\left(\mathrm{~S}_{2} \mathrm{P}(\mathrm{OEt})_{2}\right)_{2}\left(\mu-\mathrm{O}_{2} \mathrm{CMe}\right)(\mu-\mathrm{S})(\mu-\mathrm{SOBn})$ which will be abbreviated as $\mathrm{S}\left\{\mathrm{Mo}_{2}\right\} \mathrm{SOBn}$.

The three-coordinate sulfur bridges in these compounds are pyramidal, and this makes inversion isomers possible. These compounds in solution typically do show such isomers, and these are listed as distal and proximal. The distal or proximal designations are assigned relative to the p-tolylimido ligands. Thus, $\mathrm{S}\left\{\mathrm{Mo}_{2}\right\} \mathrm{SOBn}$ has two inversion isomers as shown in Figure 1.3. 


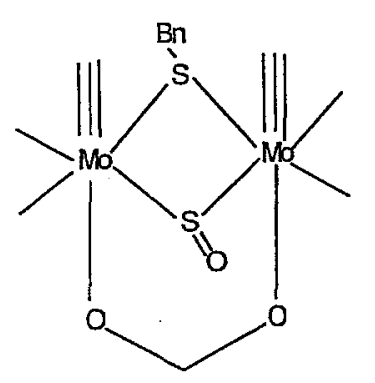

$\mathrm{BnS}\left\{\mathrm{Mo}_{2}\right\}$ SO acetate

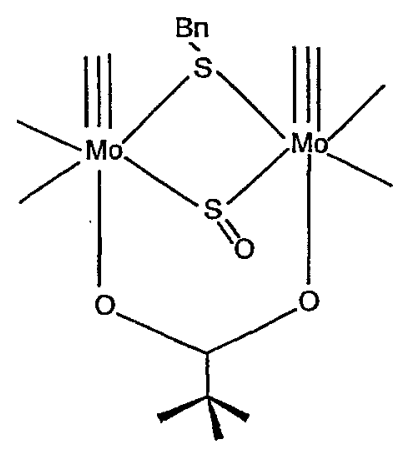

$\mathrm{BnS}\left\{\mathrm{Mo}_{2}\right\}$ SO pivalate

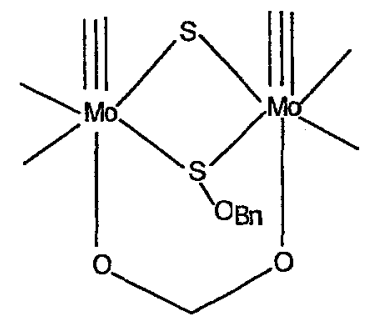

$\mathrm{S}\left\{\mathrm{Mo}_{2}\right\} \mathrm{SOBn}$

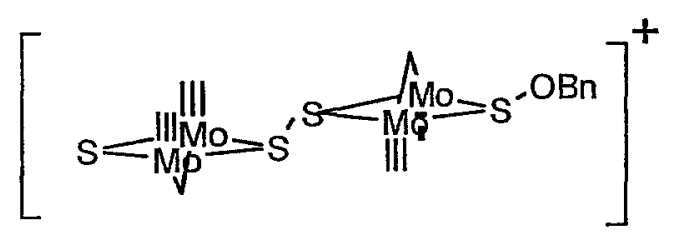

$\left[\mathrm{S}\left\{\mathrm{Mo}_{2}\right\} \mathrm{SS}\left\{\mathrm{Mo}_{2}\right\} \mathrm{SOBn}\right]^{+}$

Figure 1.2: Stick diagram of other $\mathrm{Mo}_{2} \mathrm{~S}_{2}$ core compounds 


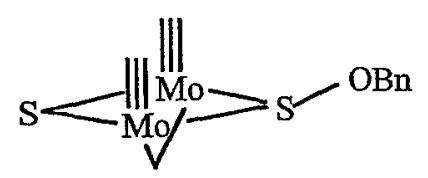

proximal

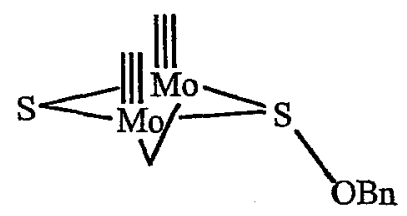

distal

Figure 1.3 Invertomers of $\mathrm{S}\left\{\mathrm{Mo}_{2}\right\} \mathrm{SOBn}$

Chapter Two compares some of the solid reactions of $\mathrm{BnS}\left\{\mathrm{Mo}_{2}\right\}$ SO derivatives. The comparisons were based on steric effect, chirality and electron withdrawal/donating groups. Previous work showed that $\mathrm{BnS}\left\{\mathrm{Mo}_{2}\right\} \mathrm{SO}$ compounds demonstrated nucleophilicity by attacking a neighboring molecule in its lattice. The mechanism is intermolecular and it involves mutual attack between neighboring molecules within the crystal lattice. Chapter Three looks at some solution reactions of $\mathrm{BnS}\left\{\mathrm{Mo}_{2}\right\} \mathrm{SO}$ which lead to the synthesis of $\mathrm{S}\left\{\mathrm{Mo}_{2}\right\} \mathrm{SOBn}$ from $\mathrm{BnS}\left\{\mathrm{Mo}_{2}\right\} \mathrm{SO}$ and $\mathrm{BnBr}$. This chapter also looks at a dimer of dimers of $\mathrm{S}\left\{\mathrm{Mo}_{2}\right\} \mathrm{SOBn}$ which is $\left[\mathrm{S}\left\{\mathrm{Mo}_{2}\right\} \mathrm{SS}\left\{\mathrm{Mo}_{2}\right\} \mathrm{SOBn}\right]^{+}$. The structure of $\left[\mathrm{S}\left\{\mathrm{SMo}_{2}\right\} \mathrm{SS}\left\{\mathrm{Mo}_{2}\right\} \mathrm{SOBn}\right]^{+}$is compared to that of $\left[\mathrm{BnS}\left\{\mathrm{Mo}_{2}\right\} \mathrm{SOEt}\right]^{+}$and $\mathrm{S}\left\{\mathrm{Mo}_{2}\right\} \mathrm{SS}\left\{\mathrm{Mo}_{2}\right\} \mathrm{S}$. 


\section{CHAPTER TWO}

\section{DECOMPOSITION STUDIES OF SO BRIDGED DIMOLYBDENUM(V) DIMER $\left[\mathrm{Mo}_{2}(\mathrm{NTo})_{2}\left(\mathrm{~S}_{2} \mathrm{P}(\mathrm{OEt})_{2}\right)_{2}\left(\mu-\mathrm{O}_{2} \mathrm{CR}\right)(\mu-\mathrm{SBn})(\mu-\mathrm{SO})\right], \mathrm{BnS}\left\{\mathrm{Mo}_{2}\right\} \mathrm{SO}$}

\subsection{Introduction}

$\mathrm{BnS}\left\{\mathrm{MO}_{2}\right\} \mathrm{SO}$, Figure 1.2, was previously reported to be thermally and photochemically unstable. ${ }^{26}$ The compound was reported to have very good solution stability, giving $\sim 1-2 \%$ decomposition after six days in $\mathrm{CDCl}_{3}$. Photolysis of a solution in $\mathrm{CDCl}_{3}$ in an NMR tube gave $1-2 \%$ reaction after 16 hours in a 12 -in., $32-W$ fluorescent ring lamp. $\mathrm{BnS}\left\{\mathrm{Mo}_{2}\right\} \mathrm{SO}$ underwent a very slow and clean reaction in the solid state. The compound furthermore decomposed quickly while standing after evaporation from solution (either air dried or from rotavapping). The compound was reported to decompose faster as a crystalline solid than when it was in solution. ${ }^{26} \mathrm{SO}_{2}$-bridged $\mathrm{BnS}\left\{\mathrm{Mo}_{2}\right\} \mathrm{SO}_{2}$, however, was very light sensitive and it presented as an impurity in $\mathrm{BnS}\left\{\mathrm{Mo}_{2}\right\} \mathrm{SO}$ which resulted in reduction of the $\mathrm{BnS}\left\{\mathrm{Mo}_{2}\right\} \mathrm{SO}$. This was clear evidence that the $\mathrm{BnS}\left\{\mathrm{Mo}_{2}\right\} \mathrm{SO}$ bridging group greatly influenced the stability of the

$\mathrm{BnS}\left\{\mathrm{Mo}_{2}\right\} \mathrm{SO} .^{15}$ The essence of this work was to check different $\mathrm{BnS}\left\{\mathrm{Mo}_{2}\right\} \mathrm{SO}$ compounds with different thiolate or carboxylate bridging groups and see how their stability is influenced by these bridging groups.

Different $\mathrm{BnS}\left\{\mathrm{Mo}_{2}\right\}$ SO compounds and the $\mathrm{MeS}\left\{\mathrm{Mo}_{2}\right\}$ SO acetate compound were synthesized and compared for their thermolytic stabilities. Prior work by former researchers on crystal-phase reactions of $\mathrm{BnS}\left\{\mathrm{Mo}_{2}\right\}$ SO showed that only temperature had an effect on the decomposition and there was no effect from light or storage atmosphere. For example, a sample that had been stored in a vacuum at normal room conditions 


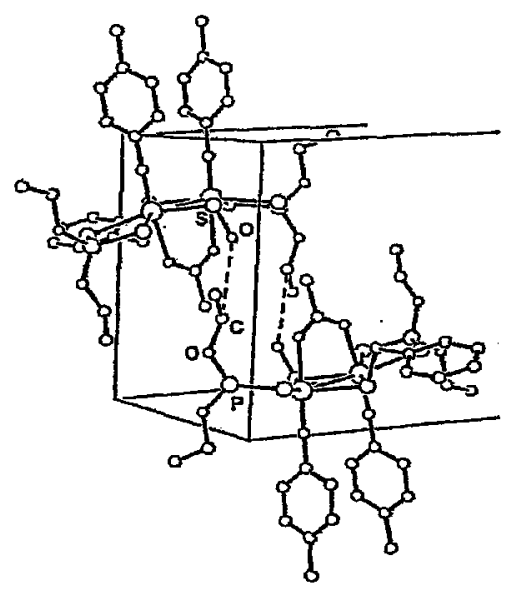

Figure 2.1: Nucleophilic faceoff between adjacent molecules in the crystal structure of $\mathrm{BnS}\left\{\mathrm{Mo}_{2}\right\} \mathrm{SO}$. The dashed lines connect oxygen from the SO bridge of one molecule to a dithiophosphate $\alpha$-carbon on the adjacent molecule. Only one interaction is labeled, but interactions are reciprocal.

decomposed $14 \%$ after 159 days, while a sample that had been air exposed in the freezer did not react in the same time. The decomposition at room temperature was $\sim 1 \%$ in 7 days.

The decomposition product was $\left[\mathrm{Mo}_{2}(\mathrm{NTo})_{2}\left(\mathrm{~S}_{2} \mathrm{P}(=\mathrm{O})(\mathrm{OEt})\right)\left(\mathrm{S}_{2} \mathrm{P}(\mathrm{OEt})_{2}\right)(\mu-\right.$ $\left.\left.\mathrm{O}_{2} \mathrm{CMe}\right)(\mu-\mathrm{SBn})(\mu-\mathrm{SOEt})\right]$, abbreviated as $\mathrm{BnS}\left\{\mathrm{Mo}_{2}(\mathrm{P}=0)\right\}$ SOEt. The reaction is tantamount to isomerization: one dithiophosphate ethyl group ends up attached to the oxygen of the bridge SO moiety. The mechanism for this reaction is intermolecular and it involves mutual attack between neighboring molecules within the crystal lattice. ${ }^{26}$ The packing of BnS $\left\{\mathrm{Mo}_{2}\right\} \mathrm{SO}$ acetate (Figure 2.1) revealed that the molecules pair off in close approach to nucleophilic attack upon each other. The neighboring molecules are related by inversion. The oxygen atom of one molecule's SO bridge is 3.52(1) $\AA$ from the $\alpha$ carbon of the ethyl group of a dithiophosphate ligand of the adjacent molecule. This distance is close to simple van der Waals contacts $\left(3.37 \AA^{22}\right)$ and the angle of approach, $\mathrm{O} \cdots \mathrm{C}-\mathrm{O}$, is $166(1)^{\circ}$, giving correct orientation for a backside attack. This attack was reciprocal for each of the molecules in the pair. It is because of this juxtaposition, 
coupled with the inherent nucleophilic behavior of the bridge $S(O)$, which provides for the solid state reaction. Though the reactions are slow at room temperature, decomposition is hastened at elevated temperatures. For example, decomposition was $50 \%$ after two days of heating at $60^{\circ} \mathrm{C}$ and $10 \%$ at $97^{\circ} \mathrm{C}$ for $30 \mathrm{~min}$.

In the present work, the pivalate and butyrate were selected to test for steric hindrance. (R)-(-)- $\alpha$-methoxyphenylacetate (MPA) was used to check the effect of chirality on decomposition. By reacting the MPA derivative of $\mathrm{BnS}\left\{\mathrm{Mo}_{2}\right\} \mathrm{SO}$, we expect to get both $\mathrm{R}, \mathrm{R}$ and $\mathrm{R}, \mathrm{S}$ chiral products of $\mathrm{BnS}\left\{\mathrm{Mo}_{2}(\mathrm{P}=\mathrm{O})\right\} \mathrm{SOE}$ MPA, which should be seen in the NMR. Also MeS $\left\{\mathrm{Mo}_{2}\right\} \mathrm{SO}$ acetate and $\mathrm{BnS}\left\{\mathrm{Mo}_{2}\right\} \mathrm{SO}$ acetate were used to see how electron enriching and electron withdrawal groups influence the solid state reactions of these compounds.

\subsection{Experimental Section}

The $\mathrm{MeS}\left\{\mathrm{Mo}_{2}\right\} \mathrm{SO}$ acetate and $\mathrm{BnS}\left\{\mathrm{Mo}_{2}\right\} \mathrm{SO}$ acetate were prepared in similar manner as previously reported. ${ }^{26} m$-chloroperbenzoic acid was prepared for use by drying a small portion $(<1 \mathrm{~g})$ of the commercial impure reagent (containing water and $m$ chlorobenzoic acid) in a desiccator for several days; the peracid/acid content of each portion was then assessed from the ${ }^{1} \mathrm{H}$ NMR spectrum and this was converted to mass percentage. In all $m$-chloroperbenzoic acid preparations used in the present work, the mass percentage was $87 \%$. The silica gel was Davisil grade 644 . Except when indicated, operations were carried out in open air. The ${ }^{31} \mathrm{P}$ and ${ }^{\mathrm{I}} \mathrm{H}$ NMR spectra were obtained on a Varian Inova500 spectrometer; results were relative to external $85 \% \mathrm{H}_{3} \mathrm{PO}_{4}$ and internal $\mathrm{Me}_{4} \mathrm{Si}$, respectively. Values for the minor invertomers are given in parentheses when they were confidently discernible.

\section{$\left[\mathrm{Mo}_{2}(\mathrm{NTo})_{2}\left(\mathrm{~S}_{2} \mathrm{P}(\mathrm{OEt})_{2}\right)_{2}\left(\mu-\mathrm{O}_{2} \mathrm{CCMe}_{3}\right)(\mu-\mathrm{SBn})(\mu-\mathrm{S})\right] ; \mathrm{BnS}\left\{\mathrm{Mo}_{2}\right\} \mathrm{S}$ pivalate}

[ $\left.\mathrm{Mo}_{4}\right](0.2088 \mathrm{~g}, 0.1248 \mathrm{mmol})$ was dissolved in $2.5 \mathrm{~mL}$ benzene; $\mathrm{Me}_{3} \mathrm{CCOOH}$ 
(0.0332 $\mathrm{g} ; 0.325 \mathrm{mmol})$ was added followed by $\mathrm{BnCl}(38 \mu \mathrm{L} ; 0.33 \mathrm{mmol})$. The subsequent addition of base $\mathrm{Et}_{3} \mathrm{~N}(44 \mu \mathrm{L} ; 0.31 \mathrm{mmol})$ resulted in the solution turning brown. The solution was stirred for $\sim 70 \mathrm{~min}$ after which it appeared light brown. The solution was rotavapped, then chased twice with THF, rotavapping each time. $2.1 \mathrm{~mL}$ of THF were added to dissolve the residue. $1.2 \mathrm{~mL}$ of $\mathrm{EtOH}: \mathrm{H}_{2} \mathrm{O}$ were added to precipitate the product, followed by $0.6 \mathrm{~mL}$ of $\mathrm{H}_{2} \mathrm{O}$. The slurry was filtered and washed with 2.1 EtOH: $\mathrm{H}_{2} \mathrm{O}$, then dried. Crude yield was $0.1616 \mathrm{~g} ; 63 \%$. Recrystallization involved dissolving $0.1616 \mathrm{~g}$ of crude $\mathrm{BnS}\{\mathrm{Mo}\} \mathrm{S}$ pivalate in $3.2 \mathrm{~mL} \mathrm{Me} 2 \mathrm{CO}$. The product was precipitated with 2:1 $\mathrm{MeOH}: \mathrm{H}_{2} \mathrm{O}$, filtered, washed with 3:1 $\mathrm{MeOH}: \mathrm{H}_{2} \mathrm{O}$ and then suction dried (0.0970 g; $38 \%$ pure yield). The ${ }^{1} \mathrm{H}$ NMR spectrum of $\mathrm{BnS}\left\{\mathrm{Mo}_{2}\right\}$ S pivalate gave the following (in ppm): $7.71 \mathrm{~d},(7.64 \mathrm{~d}), 7.48 \mathrm{t},(7.38 \mathrm{t}), \mathrm{Bn}-\mathrm{H} ; 6.71 \mathrm{~d},(6.54 \mathrm{~d}),(6.52 \mathrm{~d})$, $6.40 \mathrm{~d}$, To-H; (4.42 s), $3.39 \mathrm{~s}, \mathrm{Bn}-\mathrm{CH}_{2} ; 4.25 \mathrm{~m}, 4.01 \mathrm{~m}, \mathrm{POCH}_{2} ;(2.12 \mathrm{~s}), 2.03 \mathrm{~s}$, To-CH ; $1.37 \mathrm{t},(1.32 \mathrm{t}),(1.19 \mathrm{t}), 1.14 \mathrm{t}, \mathrm{POCCH}_{3} ; 0.69 \mathrm{~s},(0.56 \mathrm{~s}), \mathrm{C}\left(\mathrm{CH}_{3}\right)_{3}$. The ${ }^{31} \mathrm{P} \mathrm{NMR}$ spectrum of $\mathrm{BnS}\left\{\mathrm{Mo}_{2}\right\} \mathrm{S}$ pivalate gave the following results (in ppm): 116.0, (115.8).

\section{$\left[\mathrm{Mo}_{2}(\mathrm{NTo})_{2}\left(\mathrm{~S}_{2} \mathrm{P}(\mathrm{OEt})_{2}\right)_{2}\left(\mu-\mathrm{O}_{2} \mathrm{CCMe}_{3}\right)(\mu-\mathrm{SBn})(\mu-\mathrm{SO})\right] ; \mathrm{BnS}\left\{\mathrm{Mo}_{2}\right\} \mathrm{SO}$ pivalate}

A solution of $\mathrm{BnS}\left\{\mathrm{Mo}_{2}\right\}$ S pivalate $(0.0917 \mathrm{~g} ; 0.0891 \mathrm{mmol})$ in $2.2 \mathrm{~mL} \mathrm{Me} 2 \mathrm{CO}$ was chilled in an ice water bath. A solution of $87 \% \mathrm{~m}$-chloroperbenzoic acid $(0.0177 \mathrm{~g}$; $0.089 \mathrm{mmol})$ in $0.8 \mathrm{~mL}$ of $\mathrm{Me}_{2} \mathrm{CO}$ was chilled. To the solution of $\mathrm{BnS}\{\mathrm{Mo}\} \mathrm{S}$ pivalate, $\mathrm{Me}_{3} \mathrm{CCO}_{2} \mathrm{H}(0.0364 \mathrm{~g} ; 0.356 \mathrm{mmol})$ and $\mathrm{HBF}_{4}(23 \mathrm{uL} ; 0.18 \mathrm{mmol})$ were added in close

succession. The solution of $m$-chloroperbenzoic acid was then added dropwise; two rinses each of about $0.2 \mathrm{~mL} \mathrm{Me} 2 \mathrm{CO}$ were used to facilitate transfer of the $m$-chloroperbenzoic acid. The solution turned light yellow upon addition. After approximately three minutes of stirring, $\mathrm{NaHCO}_{3}(0.0605 \mathrm{~g}, 0.720 \mathrm{mmol})$ in $1.5 \mathrm{~mL} \mathrm{H}_{2} \mathrm{O}$ was then added slowly, causing the color to turn olive. After being removed from the ice bath, additional water 
was added dropwise and the solution was stirred for an additional five minutes. The mixture was allowed to settle; the supernatant was decanted and the slurry was washed with $1: 2 \mathrm{Me}_{2} \mathrm{CO}: \mathrm{H}_{2} \mathrm{O}(6 \mathrm{~mL})$. The slurry was filtered and the solid was suction dried to produce an olive solid ( $0.0899 \mathrm{~g} ; 97 \%$ crude yield).

Crude product $(0.0899 \mathrm{~g})$ in $4.5 \mathrm{~mL} \mathrm{CH} \mathrm{CH}_{2}$ was stirred with $0.9000 \mathrm{~g}$ silica gel for several minutes and the mixture was filtered. Additionally, $6.8 \mathrm{~mL} \mathrm{CH} \mathrm{Cl}_{2}$ was used to wash the silica gel fraction. The orange silica gel fraction was washed slowly with 9 $\mathrm{mL}$ of $\mathrm{Me}_{2} \mathrm{CO}$ which removed the product, giving an olive filtrate and an off-white silica gel remainder. The filtrate was rotavapped; the residue was dissolved in $3 \mathrm{~mL}$ of EtOH and the product was precipitated slowly with $3.1 \mathrm{~mL} \mathrm{H}_{2} \mathrm{O}$. The product was filtered, washed with 1:2 EtOH: $\mathrm{H}_{2} \mathrm{O}$, and then dried $(0.0643 \mathrm{~g} ; 69 \%)$. The product was stored in a freezer to avoid thermal decomposition. The ${ }^{1} \mathrm{H} N M R$ spectrum of $\mathrm{BnS}\left\{\mathrm{Mo}_{2}\right\} \mathrm{SO}$ pivalate in Figure 2.2 gave the following (in ppm): (7.68 d), $7.61 \mathrm{~d}, 7.47 \mathrm{t}, 7.38 \mathrm{t}, \mathrm{Bn}-\mathrm{H}$; (6.83 d), (6.72 d), 6.55 d, 6.41 d, To-H; (4.42 s), $3.57 \mathrm{~s}, \mathrm{Bn}-\mathrm{CH}_{2} ; 4.26 \mathrm{~m}, 3.96 \mathrm{~m} \mathrm{POCH}_{2}$; $2.03 \mathrm{~s}, \mathrm{To}-\mathrm{CH}_{3} ; 1.37 \mathrm{t}, 1.18 \mathrm{t}, \mathrm{POCCH}_{3} ; 0.84 \mathrm{~s},(0.73 \mathrm{~s}), \mathrm{C}\left(\mathrm{CH}_{3}\right)_{3}$. The ${ }^{31} \mathrm{P} N M R$ in Figure 2.3 gave the following results (115.4 ppm), (115.1 ppm), $114.5 \mathrm{ppm}$. $\left[\mathrm{Mo}_{2}(\mathrm{NTo})_{2}\left(\mathrm{~S}_{2} \mathrm{P}(\mathrm{OEt})_{2}\right)_{2}\left(\mu-\mathrm{O}_{2} \mathrm{CCH}(\mathrm{OMe}) \mathrm{C}_{6} \mathrm{H}_{5}\right)(\mu-\mathrm{SBn})(\mu-\mathrm{S})\right] ;$ BnS $\left\{\mathrm{Mo}_{2}\right\} \mathrm{S}$ MPA

[ $\left.\mathrm{Mo}_{4}\right](0.6280 \mathrm{~g} ; 0.3753 \mathrm{mmol})$ was dissolved in $10 \mathrm{~mL}$ benzene; MPA $(0.1630 \mathrm{~g}$; $0.9800 \mathrm{mmol})$ was added followed by $\mathrm{BnCl}(0.11 \mathrm{~mL} ; 0.96 \mathrm{mmol})$. Addition of base $\mathrm{Et}_{3} \mathrm{~N}(0.13 \mathrm{~mL} ; 0.94 \mathrm{mmol})$ resulted in the solution turning brown. The solution was stirred for $\sim 70 \mathrm{~min}$ after which it appeared light brown. The solution was rotavapped and chased twice with THF, rotavapping each time. $2.1 \mathrm{~mL}$ of THF was added to dissolve the residue. $1.2 \mathrm{~mL}$ of $2: 1 \mathrm{EtOH}: \mathrm{H}_{2} \mathrm{O}$ was added to precipitate the product, followed by 0.6 $\mathrm{mL}$ of $\mathrm{H}_{2} \mathrm{O}$. The slurry was filtered; the solid was washed with 2:1 EtOH: $\mathrm{H}_{2} \mathrm{O}$ and then dried (0.7840 g; $96 \%$ crude yield). 
The recrystallization involved dissolving $0.7840 \mathrm{~g}$ of crude $\mathrm{BnS}\left\{\mathrm{Mo}_{2}\right\} \mathrm{S} \mathrm{MPA}$ in $3.2 \mathrm{~mL} \mathrm{Me} 2 \mathrm{CO}$. The product was precipitated with 2:1 MeOH: $\mathrm{H}_{2} \mathrm{O}$, filtered, washed with 3:1 MeOH: $\mathrm{H}_{2} \mathrm{O}$, and then suction dried $\left(0.6280 \mathrm{~g} ; 76 \%\right.$ pure yield). The ${ }^{1} \mathrm{H} N M R$ spectrum of $\mathrm{BnS}\left\{\mathrm{Mo}_{2}\right\} \mathrm{S} M P A$ gave the following (in ppm): (7.64 d), (7.43 t), $7.35 \mathrm{t}$, $7.28 \mathrm{~d}, \mathrm{Bn}-\mathrm{H}$; 7.15 t, 7.06 t, 6.87 d, phenyl-H; (6.77 t), (6.57 d), 6.50 d, 6.39 t, To-H; (4.61 m), $4.31 \mathrm{~m}, 4.08 \mathrm{~m},(3.85 \mathrm{~m}), \mathrm{POCH}_{2} ; 3.94 \mathrm{~s},(3.79 \mathrm{~s}), \mathrm{Bn}_{-} \mathrm{CH}_{2} ; 3.16 \mathrm{~s},(2.99 \mathrm{~s})$, O$\mathrm{CH}_{3} ; 2.87$ d, 2.69 d, $\alpha-\mathrm{C}-\mathrm{H} ; 2.13 \mathrm{~s}, 2.14$ s, To-CH $3 ; 1.46$ t, 1.39 t, 1.21 t, 1.18 t, $\mathrm{POCCH}_{3}$. The ${ }^{31} \mathrm{P}$ NMR spectrum gave the following results (in ppm):115.5, (115.4), (115.3) and 115.2.

\section{$\left[\mathrm{Mo}_{2}(\mathrm{NTo})_{2}\left(\mathrm{~S}_{2} \mathrm{P}(\mathrm{OEt})_{2}\right)_{2}\left(\mu-\mathrm{O}_{2} \mathrm{CCH}(\mathrm{OMe}) \mathrm{C}_{6} \mathrm{H}_{5}\right)(\mu-\mathrm{SBn})(\mu-\mathrm{SO})\right] ; \mathrm{BnS}\left\{\mathrm{Mo}_{2}\right\} \mathrm{SO}$} MPA

A solution of $\mathrm{BnS}\left\{\mathrm{Mo}_{2}\right\} \mathrm{S}$ MPA $(0.6280 \mathrm{~g}, 0.575 \mathrm{mmol})$ was dissolved in $4.4 \mathrm{~mL}$ $\mathrm{Me}_{2} \mathrm{CO}$ in an ice water bath. A solution of $87 \%$ m-chloroperbenzoic acid $(0.1140 \mathrm{~g} ; 0.57$ mmol) in $1.2 \mathrm{~mL}$ of $\mathrm{Me}_{2} \mathrm{CO}$ was also chilled. To the solution of $\mathrm{BnS}\left\{\mathrm{Mo}_{2}\right\} \mathrm{S}$ MPA, MPA $(0.3820 \mathrm{~g} ; 2.290 \mathrm{mmol})$ and $\mathrm{HBF}_{4}(16 \mathrm{uL} ; 0.12 \mathrm{mmol})$ were added in close succession. The solution of $m$-chloroperbenzoic acid was added dropwise; two rinses each of about $0.5 \mathrm{~mL} \mathrm{Me} 2 \mathrm{CO}$ were used to facilitate transfer of the $m$-chloroperbenzoic acid. The solution turned pale orange upon the addition of $m$-chloroperbenzoic acid. After approximately three minutes of stirring, $\mathrm{NaHCO}_{3}(0.3860 \mathrm{~g}, 4.600 \mathrm{mmol})$ in $2.5 \mathrm{~mL} \mathrm{H} \mathrm{H}_{2} \mathrm{O}$ was then added slowly, causing the color to turn olive.

After being removed from the ice bath, additional $\mathrm{H}_{2} \mathrm{O}$ was added dropwise and the solution was then stirred for an additional five minutes. The mixture was allowed to settle; this was decanted and washed with 1:2 $\mathrm{Me}_{2} \mathrm{CO}: \mathrm{H}_{2} \mathrm{O}(6 \mathrm{~mL})$. The product was filtered and suction dried to produce a brown solid $(0.7280 \mathrm{~g}, 73 \%$ crude yield). Crude product $(0.7280 \mathrm{~g})$ in $30 \mathrm{~mL} \mathrm{CH}_{2} \mathrm{Cl}_{2}$ was stirred in $7.250 \mathrm{~g}$ silica gel for several minutes 
and the mixture was the filtered. Additionally, $9.9 \mathrm{~mL} \mathrm{CH}_{2} \mathrm{Cl}_{2}$ was used to wash the silica gel fraction. The pale yellow silica gel fraction was then washed slowly with $13 \mathrm{~mL}$ of $\mathrm{Me}_{2} \mathrm{CO}$ which removed the product, giving a dark black filtrate and off-white silica gel remainder. The filtrate was rotavapped. The residue was dissolved in $1.7 \mathrm{~mL}$ of EtOH and the product was precipitated slowly with $1 \mathrm{~mL} \mathrm{H}_{2} \mathrm{O}$. The product was washed with 1:2 EtOH: $\mathrm{H}_{2} \mathrm{O}$, filtered and dried. The product was a purple crystalline solid and was stored in a freezer to avoid thermal decomposition $(0.6030 \mathrm{~g}, 95 \%$ pure yield $)$. The ${ }^{1} \mathrm{H}$ NMR spectrum in Figure 2.4 of $\mathrm{BnS}\left\{\mathrm{Mo}_{2}\right\}$ SO MPA gave the following (in ppm): $7.34 \mathrm{t}$, $7.28 \mathrm{~d}, 7.21 \mathrm{~d}, \mathrm{Bn}-\mathrm{H} ; 7.08$ t, $7.02 \mathrm{~d}, 6.80 \mathrm{~d}$, phenyl-H; $6.53 \mathrm{~d}, 6.41 \mathrm{~d}$, To-H; (4.36 s), 3.42, $\mathrm{Bn}-\mathrm{CH}_{2} ;(4.44 \mathrm{~m}),(4.32 \mathrm{~m}), 4.18 \mathrm{~m}, 4.03 \mathrm{~m}, 4.00 \mathrm{~m}, \mathrm{POCH}_{2} ; 3.44 \mathrm{~s}, \mathrm{O}-\mathrm{CH}_{3} ; 3.10$ d, $2.60 \mathrm{~d}, \alpha-\mathrm{C}-\mathrm{H} ; 2.05 \mathrm{~s}, 1.96 \mathrm{~s}$, To- $\mathrm{CH}_{3} ; 1.45$ t, (1.24 t), $1.19 \mathrm{t},(1.12 \mathrm{t}), \mathrm{POCCH}_{3}$. The ${ }^{31} \mathrm{P}$ NMR spectrum at Figure 2.5 gave the following results (in ppm): (114.8), 114.2 and 113.7 .

\section{$\left[\mathrm{Mo}_{2}(\mathrm{NTo})_{2}\left(\mathrm{~S}_{2} \mathrm{P}(\mathrm{OEt})_{2}\right)_{2}\left(\mu-\mathrm{O}_{2} \mathrm{CPr}\right)(\mu-\mathrm{SBn})(\mu-\mathrm{S})\right] ; \mathrm{BnS}\left\{\mathrm{Mo}_{2}\right\} \mathrm{S}$ butyrate}

[ $\left.\mathrm{Mo}_{4}\right]$ ( $\left.0.2090 \mathrm{~g}, 0.1249 \mathrm{mmol}\right)$ was dissolved in $5 \mathrm{~mL}$ benzene; $\mathrm{PrCOOH}(29.7$ $\mu \mathrm{L}, 0.325 \mathrm{mmol})$ was added followed by $\mathrm{BnCl}(37.5 \mu \mathrm{L}, 0.326 \mathrm{mmol})$. The subsequent addition of base $\mathrm{Et}_{3} \mathrm{~N}(43.5 \mu \mathrm{L}, 0.313 \mathrm{mmol})$ resulted in the solution turning brown.

The solution was stirred for $70 \mathrm{~min}$ after which it appeared light brown/dark red. The solution was rotavapped, then chased twice with THF, rotavapping each time. 0.4 $\mathrm{mL}$ of THF was added to dissolve the residue. $1.2 \mathrm{~mL}$ of $\mathrm{EtOH}: \mathrm{H}_{2} \mathrm{O}$ were added to precipitate the product, followed by $2 \mathrm{~mL}$ of $\mathrm{H}_{2} \mathrm{O}$. The product was filtered and washed with 2:1EtOH: $\mathrm{H}_{2} \mathrm{O}$, and then dried ( $0.1713 \mathrm{~g} ; 68 \%$ crude yield). The recrystallization involved dissolving $0.1713 \mathrm{~g}$ of crude $\mathrm{BnS}\{\mathrm{Mo}\} \mathrm{S}$ butyrate in $3.2 \mathrm{~mL} \mathrm{Me} \mathrm{CO}_{2}$. The product was precipitated with 2:1 $\mathrm{MeOH}: \mathrm{H}_{2} \mathrm{O}$, filtered, rinsed and washed with 3:1 MeOH: $\mathrm{H}_{2} \mathrm{O}$; this was dried to give an orange solid ( $0.0918 \mathrm{~g} ; 36 \%$ pure yield). The 
${ }^{1} \mathrm{H} \mathrm{NMR}$ spectrum of $\mathrm{BnS}\left\{\mathrm{Mo}_{2}\right\} \mathrm{S}$ butyrate gave the following (in ppm): (7.66 d), $7.62 \mathrm{~d}$, 7.49 t, (7.36 t), Bn-H; (6.72 d), (6.58 d), 6.51 d, 6.41 d, ToH; (4.39 s), 3.43 s, Bn-CH $4.23 \mathrm{~m}, 4.15 \mathrm{~m}, \mathrm{POCH}_{2} ;(2.12 \mathrm{~s}), 2.03 \mathrm{~s}, \mathrm{To}-\mathrm{CH}_{3} ; 1.54 \mathrm{t}, \mathrm{O}_{2} \mathrm{CCH}_{2} ; 1.36 \mathrm{t},(1.25 \mathrm{t}),(1.21$ t), 1.19 t, $\mathrm{POCCH}_{3} ; 1.15$ sextet, (0.98 sextet), $\mathrm{O}_{2} \mathrm{CCCH}_{2} ; 0.62 \mathrm{t},(0.58 \mathrm{t}), \mathrm{O}_{2} \mathrm{CCCCH}_{3}$. The ${ }^{31} \mathrm{P} N M R$ spectrum of $\mathrm{BnS}\left\{\mathrm{Mo}_{2}\right\} \mathrm{S}$ butyrate gave the following results (in $\mathrm{ppm}$ ): (115.4), 115.2.

\section{$\left[\mathrm{Mo}_{2}(\mathrm{NTo})_{2}\left(\mathrm{~S}_{2} \mathrm{P}(\mathrm{OEt})_{2}\right)_{2}\left(\mu-\mathrm{O}_{2} \mathrm{CPr}\right)(\mu-\mathrm{SBn})(\mu-\mathrm{SO})\right] ; \mathrm{BnS}\left\{\mathrm{Mo}_{2}\right\} \mathrm{SO}$ butyrate}

A solution of $\mathrm{BnS}\left\{\mathrm{Mo}_{2}\right\} \mathrm{S}$ butyrate $(0.0847 \mathrm{~g}, 0.0835 \mathrm{mmol})$ was dissolved in 2.2 $\mathrm{mL} \mathrm{Me} 2 \mathrm{CO}$ in ice water bath. A solution of $87 \% \mathrm{~m}$-chloroperbenzoic acid $(0.0624 \mathrm{~g}$, $0.32 \mathrm{mmol}$ ) in $1.2 \mathrm{~mL}$ of $\mathrm{Me}_{2} \mathrm{CO}$ was also chilled. To the solution of $\mathrm{BnS}\{\mathrm{Mo}\} \mathrm{S}$ butyrate, $\mathrm{PrCO}_{2} \mathrm{H}(31 \mathrm{uL}, 0.34 \mathrm{mmol})$ and $\mathrm{HBF}_{4}(22 \mathrm{uL}, 0.17 \mathrm{mmol})$ were added in close succession. $m$-chloroperbenzoic acid was added dropwise; two rinses each of about 0.3 $\mathrm{mL} \mathrm{Me}_{2} \mathrm{CO}$ were used to facilitate transfer of the $m$-chloroperbenzoic acid. The solution turned pale orange upon addition.

After approximately three minutes of stirring, $\mathrm{NaHCO}_{3}(0.0561 \mathrm{~g}, 0.670 \mathrm{mmol})$

in $2.0 \mathrm{~mL} \mathrm{H} \mathrm{H}_{2} \mathrm{O}$ was then added slowly, causing the color to turn red. After being removed from the ice bath, additional water was added dropwise and the solution was stirred for an additional five minutes. The mixture was allowed to settle, the supernatant was decanted and the slurry was washed with $1: 3 \mathrm{Me}_{2} \mathrm{CO}: \mathrm{H}_{2} \mathrm{O}(6 \mathrm{~mL})$. The slurry was filtered and the solid was suction dried to produce a brown color $(0.0859 \mathrm{~g}, 99 \%$ crude yield).

The crude product of $\mathrm{BnS}\left\{\mathrm{Mo}_{2}\right\} \mathrm{SO}$ butyrate $(0.0859 \mathrm{~g})$ was dissolved in $4.3 \mathrm{~mL}$ $\mathrm{CH}_{2} \mathrm{Cl}_{2}$ and stirred with $0.9050 \mathrm{~g}$ silica gel for several minutes. The mixture was filtered. Additionally $6.4 \mathrm{~mL} \mathrm{CH} \mathrm{Cl}_{2}$ was used to wash the silica gel fraction allowing the unreacted $\mathrm{BnS}\left\{\mathrm{Mo}_{2}\right\} \mathrm{S}$ butyrate to pass through the silica while $\mathrm{BnS}\left\{\mathrm{Mo}_{2}\right\} \mathrm{SO}$ butyrate remained attached to the silica gel. 
The yellow silica gel fraction was washed slowly with $9 \mathrm{~mL}$ of $\mathrm{Me}_{2} \mathrm{CO}$ which removed the product, giving an olive filtrate and an off-white silica gel remainder. The filtrate was rotavapped; the residue was dissolved in $2.2 \mathrm{~mL}$ of EtOH and the product was then precipitated slowly with $2.7 \mathrm{~mL} \mathrm{H}_{2} \mathrm{O}$. The product was washed, filtered with 1:3 EtOH: $\mathrm{H}_{2} \mathrm{O}$, and dried. The product was a dark green solid and was stored in a freezer to avoid thermal decomposition $\left(0.0652 \mathrm{~g} ; 76 \%\right.$ pure yield). The ${ }^{1} \mathrm{H}$ NMR spectrum in Figure 2.6 gave the following (in ppm): (7.65 d), $7.61 \mathrm{~d}, 7.47 \mathrm{t}, 7.38 \mathrm{t}, \mathrm{Bn}-\mathrm{H}$; (6.82 d), (6.75 t), $6.59 \mathrm{~d},(6.51 \mathrm{~d}), 6.40 \mathrm{~d}$, To-H; (4.42 s), $3.55 \mathrm{~s}, \mathrm{Bn}-\mathrm{CH}_{2} ; 4.25 \mathrm{~m}, 3.55 \mathrm{~m}, \mathrm{POCH}_{2}$; (2.18 s), (2.11 s), $2.03 \mathrm{~s}$, To- $\mathrm{CH}_{3} ; 1.83$ t, $\mathrm{O}_{2} \mathrm{CCH}_{2} ; 1.34 \mathrm{t}, 1.15 \mathrm{t}, \mathrm{POCCH}_{3} ; 1.25 \mathrm{~m}$, $\mathrm{O}_{2} \mathrm{CCCH}_{2} ; 0.73 \mathrm{t},(0.62 \mathrm{t}), \mathrm{O}_{2} \mathrm{CCCCH}_{3}$. The NMR results for ${ }^{31} \mathrm{P}$ in Figure 2.7 gave the following results (in ppm): (114.5), 113.9 .

\section{Decomposition}

For each experiment, approximately $20 \mathrm{mg}$ of each $\mathrm{BnS}\left\{\mathrm{Mo}_{2}\right\}$ SO derivative were put into separate NMR tubes. The samples were thermolyzed as dry solids for $2 \mathrm{~h}$ and $8 \mathrm{~h}$ in a warm water bath at $60^{\circ} \mathrm{C}$. After the $2 \mathrm{~h}$ and the $8 \mathrm{~h}$ time frame, the NMR tubes were removed from the water bath and allowed to cool to room temperature. Approximately $0.7 \mathrm{~mL}$ of $\mathrm{CDCl}_{3}$ was added to each NMR tube and ${ }^{31} \mathrm{P} \mathrm{NMR}$ spectra were obtained to see the levels of decomposition. The ${ }^{31} \mathrm{P}$ spectrum shown in Figures 2.8 to 2.17 show different levels of decomposition for the $2 \mathrm{~h}$ and $8 \mathrm{~h}$ period.

\section{Results}

Synthesis of the new $\mathrm{BnS}\left\{\mathrm{Mo}_{2}\right\}$ SO derivatives was dome in the same manner as the synthesis of $\mathrm{BnS}\left\{\mathrm{Mo}_{2}\right\} \mathrm{SO}$ acetate but, in place of $\mathrm{MeCOOH}$ reagent, other organic acids were used thereby giving other $\mathrm{R}$ derivatives. In the case of $\mathrm{PrCOOH}$ (butyric acid) the $\mathrm{R}$ group is $\mathrm{Pr}$. In the case of $\mathrm{Me}_{3} \mathrm{CCOOH}$ (pivalic acid), the $\mathrm{R}$ group is $\mathrm{Me}_{3} \mathrm{C}$. Using MPA, $\mathrm{C}_{6} \mathrm{H}_{5} \mathrm{CH}(\mathrm{OMe})$ is the $\mathrm{R}$ group. In the case of $\mathrm{MeS}\left\{\mathrm{Mo}_{2}\right\} \mathrm{SO}$ acetate, the $\mathrm{R}$ group 
was $\mathrm{Me}$ similar to $\mathrm{BnS}\left\{\mathrm{Mo}_{2}\right\} \mathrm{SO}$ acetate, but in this case the benzyl thiolate group was substituted by methyl thiolate.

As previously done, $\mathrm{BnS}\left\{\mathrm{Mo}_{2}\right\} \mathrm{SO}$ acetate was prepared from the oxygenation of the sulfide bridge of $\mathrm{BnS}\left\{\mathrm{Mo}_{2}\right\} \mathrm{S}$ using $87 \%$ m-chloroperbenzoic acid in $\mathrm{Me}_{2} \mathrm{CO}$ at $0^{\circ} \mathrm{C}$ in the presence of excess acid. Separation of the $\mathrm{BnS}\left\{\mathrm{Mo}_{2}\right\} \mathrm{SO}$ acetate from unreacted $\mathrm{BnS}\left\{\mathrm{MO}_{2}\right\} \mathrm{S}$ and small amounts of other impurities was done by binding $\mathrm{BnS}\left\{\mathrm{Mo}_{2}\right\} \mathrm{SO}$ acetate to silica gel in $\mathrm{CH}_{2} \mathrm{Cl}_{2}$ while impurities wash through. The desired $\mathrm{BnS}\left\{\mathrm{Mo}_{2}\right\} \mathrm{SO}$ was then released from the silica gel with $\mathrm{Me}_{2} \mathrm{CO}$. The reaction equation is given in eq

\section{1.}

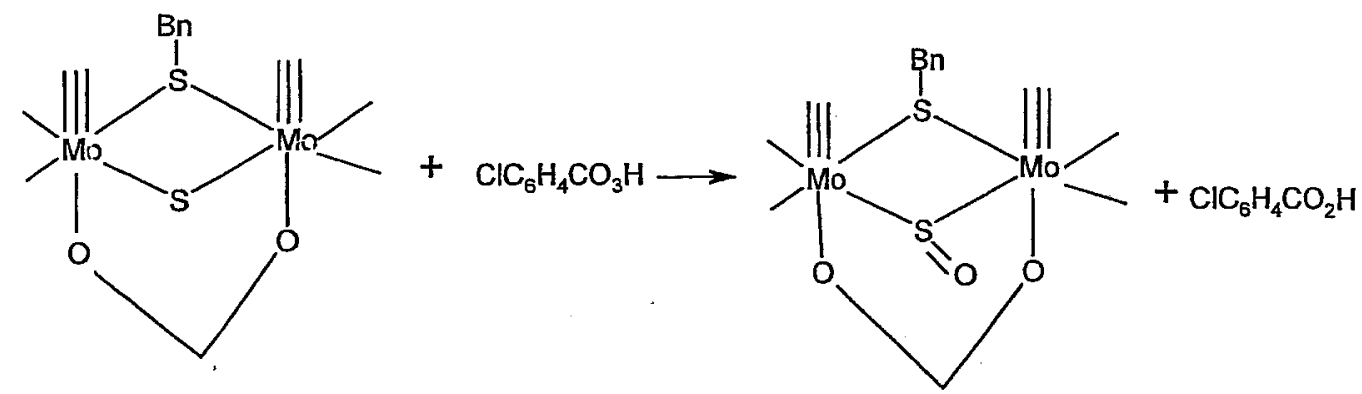

This peroxide reaction is carried out in excess $\mathrm{MeCO}_{2} \mathrm{H}$ and $\mathrm{HBF}_{4}$ to avoid a second oxygenation of the $\mathrm{BnS}\left\{\mathrm{Mo}_{2}\right\} \mathrm{SO}$ acetate to give $\mathrm{BnS}\left\{\mathrm{Mo}_{2}\right\} \mathrm{SO}_{2}$ acetate. Furthermore, addition of excess $\mathrm{MeCO}_{2} \mathrm{H}$ is to avoid substitution of the carboxylate bridge from the dimolybdenum core. ${ }^{23}$ Neutralization with $\mathrm{NaHCO}_{3}$ gives the dark olive $\mathrm{BnS}\left\{\mathrm{Mo}_{2}\right\} \mathrm{SO}$.

All $\mathrm{BnS}\left\{\mathrm{Mo}_{2}\right\} \mathrm{SO}$ compounds and the $\mathrm{MeS}\left\{\mathrm{Mo}_{2}\right\} \mathrm{SO}$ acetate compound, with the exception of $\mathrm{BnS}\left\{\mathrm{Mo}_{2}\right\}$ SO MPA, underwent similar decomposition by dealkylation of a diethyl dithiophosphate ligand, to produce the neutral complex $\mathrm{RS}\left\{\mathrm{Mo}_{2}(\mathrm{P}=0)\right\} \mathrm{SOEt}$, which contains two dithiophosphate ligand types, $(\mathrm{EtO})_{2} \mathrm{PS}_{2}{ }^{-}$and $\mathrm{EtO}(\mathrm{O}) \mathrm{PS}_{2}{ }^{2-24,25}$ As explained earlier in this chapter, the RS $\left\{\mathrm{Mo}_{2}\right\}$ SO compounds attack each other and the rate of the reaction of these compounds in the crystal phase is greatly influenced by their 
arrangements. The closer the oxygen of one molecule's SO bridge to the $\alpha$-carbon of an ethyl group of a dithiophosphate ligand of the adjacent molecule, then the easier is the back side attack. Eq 2.3 shows the solid state reaction of a pair of $\mathrm{BnS}\left\{\mathrm{Mo}_{2}\right\} \mathrm{SO}$ molecules.

$$
\mathrm{BnS}\left\{\mathrm{Mo}_{2}\right\} \mathrm{SO}+\mathrm{BnS}\left\{\mathrm{Mo}_{2}\right\} \mathrm{SO} \longrightarrow 2 \mathrm{BnS}\left\{\mathrm{Mo}_{2}(\mathrm{PO})\right\} \mathrm{SOEt}
$$

From the results in Table 2.1, the stability is in the order (from lowest to greatest) $\operatorname{MeS}\left\{\mathrm{Mo}_{2}\right\}$ SO acetate $<\mathrm{BnS}\left\{\mathrm{Mo}_{2}\right\}$ SO pivalate $<\mathrm{BnS}\left\{\mathrm{Mo}_{2}\right\}$ SO acetate $<\mathrm{BnS}\left\{\mathrm{Mo}_{2}\right\}$ SO butyrate $<\mathrm{BnS}\left\{\mathrm{Mo}_{2}\right\}$ SO MPA. In comparing different carboxylate bridges in structures of $\mathrm{BnS}\left\{\mathrm{Mo}_{2}\right\} \mathrm{SO} \mathrm{MPA}, \mathrm{BnS}\left\{\mathrm{Mo}_{2}\right\}$ SO pivalate, $\mathrm{BnS}\left\{\mathrm{Mo}_{2}\right\}$ SO acetate and $\mathrm{BnS}\left\{\mathrm{Mo}_{2}\right\} \mathrm{SO}$ butyrate, steric bulkiness may be another factor influencing the rate of decomposition. $\mathrm{BnS}\left\{\mathrm{Mo}_{2}\right\}$ SO MPA did not decompose at $60^{\circ} \mathrm{C}$ for $8 \mathrm{~h}$. The steric bulk of $\mathrm{BnS}\left\{\mathrm{Mo}_{2}\right\}$ SO MPA could hinder the $\mathrm{O}$ atom of one molecule's SO from approaching the $\alpha$-carbon of an ethyl group of a dithiophosphate ligand on the adjacent molecule. Further thermolysis at a higher temperature of $100^{\circ} \mathrm{C}$ for $2 \mathrm{~h}$, however, suggested that it first formed $\mathrm{BnS}\left\{\mathrm{Mo}_{2}\right\} \mathrm{S}$ based on the ${ }^{31} \mathrm{P}$ NMR spectrum in Figures 2.19 at the end of the Chapter. The ${ }^{31} \mathrm{P}$ spectrum in Figure 2.19 of the thermolysed $\mathrm{BnS}\left\{\mathrm{Mo}_{2}\right\} \mathrm{SO}$ MPA at the end of the chapter showed peaks at 115.5 and $115.2 \mathrm{ppm}$ which correspond to the ${ }^{31} \mathrm{P}$ NMR spectrum of the $\mathrm{BnS}\left\{\mathrm{Mo}_{2}\right\} \mathrm{S} M P A$. If we were to use bulkness as a justification of these results since bulkiness hinders the nucleophilic attack, the order of bulkiness is $\mathrm{BnS}\left\{\mathrm{Mo}_{2}\right\}$ SO pivalate $>\mathrm{BnS}\left\{\mathrm{Mo}_{2}\right\}$ SO butyrate $>\mathrm{BnS}\left\{\mathrm{Mo}_{2}\right\}$ SO acetate; this would be the sequence we would expect to see for the thermolysis stability.

If we were to use to aqueous $\mathrm{K}_{\mathrm{b}}$ values to justify this trend; the $\mathrm{K}_{\mathrm{b}}$ value for the acetate is $5.6 \times 10^{-10}$, that of the butyrate is $6.6 \times 10^{-10}$ and the $\mathrm{K}_{\mathrm{b}}$ value of the pivalate is 
Table 2.1: Thermolysis Studies of $\mathrm{BnS}\left\{\mathrm{Mo}_{2}\right\} \mathrm{SO}$ compounds

$\begin{array}{ll}\text { Compound } & \begin{array}{l}\% \text { decomposition after } \\ 2 \mathrm{~h} \text { of thermolysis }\end{array} \\ \end{array}$

$\begin{array}{lcl}\mathrm{BnS}\left\{\mathrm{Mo}_{2}\right\} \mathrm{SO} \text { acetate } & 2.3( \pm 0.2) & 6.9( \pm 0.2) \\ \mathrm{BnS}\left\{\mathrm{Mo}_{2}\right\} \text { SO pivalate } & 7.4( \pm 0.1) & 7.8( \pm 0.2) \\ \mathrm{BnS}\left\{\mathrm{Mo}_{2}\right\} \text { SO MPA } & 0 & 0 \\ \mathrm{BnS}\left\{\mathrm{Mo}_{2}\right\} \text { SO butyrate } & 0 & 5.3( \pm 0.1) \\ \mathrm{MeS}\left\{\mathrm{Mo}_{2}\right\} \mathrm{SO} \text { acetate } & 19.9( \pm 1.3) & 48.1( \pm 1.2)\end{array}$

$1 \times 10^{-9}$, we would expect that the one with the highest $\mathrm{K}_{\mathrm{b}}$ will be the least stable. There is a general tendency that the greater the $\mathrm{K}_{\mathrm{b}}$, the greater the tendency for ligand electron donation. Presently, however, the actual sequence of thermosis stability is contrary to this as the order is $\mathrm{BnS}\left\{\mathrm{Mo}_{2}\right\} \mathrm{SO}$ butyrate $>\mathrm{BnS}\left\{\mathrm{Mo}_{2}\right\} \mathrm{SO}$ acetate $>\mathrm{BnS}\left\{\mathrm{Mo}_{2}\right\}$ SO pivalate. The reason for this sequence could be due to a combination of factors which include electron releasing, steric bulkiness and arrangement in solid state. Without the crystal structure of these compounds it is very difficult to explain this trend. As for the $\mathrm{MeS}\left\{\mathrm{Mo}_{2}\right\} \mathrm{SO}$ acetate, besides having the greatest decomposition, the ${ }^{31} \mathrm{P}$ spectrum also suggests the presence of another product being formed during decomposition at $81.5 \mathrm{ppm}$ and $114 \mathrm{ppm}$ that could not be identified. By reacting the MPA derivative of $\mathrm{BnS}\left\{\mathrm{Mo}_{2}\right\} \mathrm{SO}$ we expected to get both $\mathrm{R}, \mathrm{R}$ and $\mathrm{R}, \mathrm{S}$ chiral products of $\mathrm{BnS}\left\{\mathrm{Mo}_{2}(\mathrm{P}=0)\right\}$ SOEt MPA, but this was not the case as the $\mathrm{BnS}\left\{\mathrm{Mo}_{2}\right\}$ SO MPA did not undergo de-ethylation as we expected. Thus, the $\mathrm{R}, \mathrm{R}$ and $\mathrm{R}, \mathrm{S}$ chiral products of $\mathrm{BnS}\left\{\mathrm{Mo}_{2}(\mathrm{P}=0)\right\} \mathrm{SOEt}$ were not seen in the NMR. 
In conclusion, the oxygen of the $S(O)$ is nucleophilic in crystalline phase whilst the ethyl of the diphosphate ligand is electrophilic. In this crystalline phase, $\mathrm{BnS}\left\{\mathrm{Mo}_{2}\right\}$ SO compounds followed the same mechanism by which $\mathrm{BnS}\left\{\mathrm{Mo}_{2}\right\} \mathrm{SO}$ compounds demonstrated nucleophilic behavior, with the exception of $\mathrm{BnS}\left\{\mathrm{Mo}_{2}\right\} \mathrm{SO}$ MPA for which the reaction mechanism is unknown. These experiments were not done in solution phase as previous work on these compounds proved that they were relatively stable in solution. ${ }^{26}$ It would have been interesting to compare their thermolysis stabilities in polar and non polar solvents. 


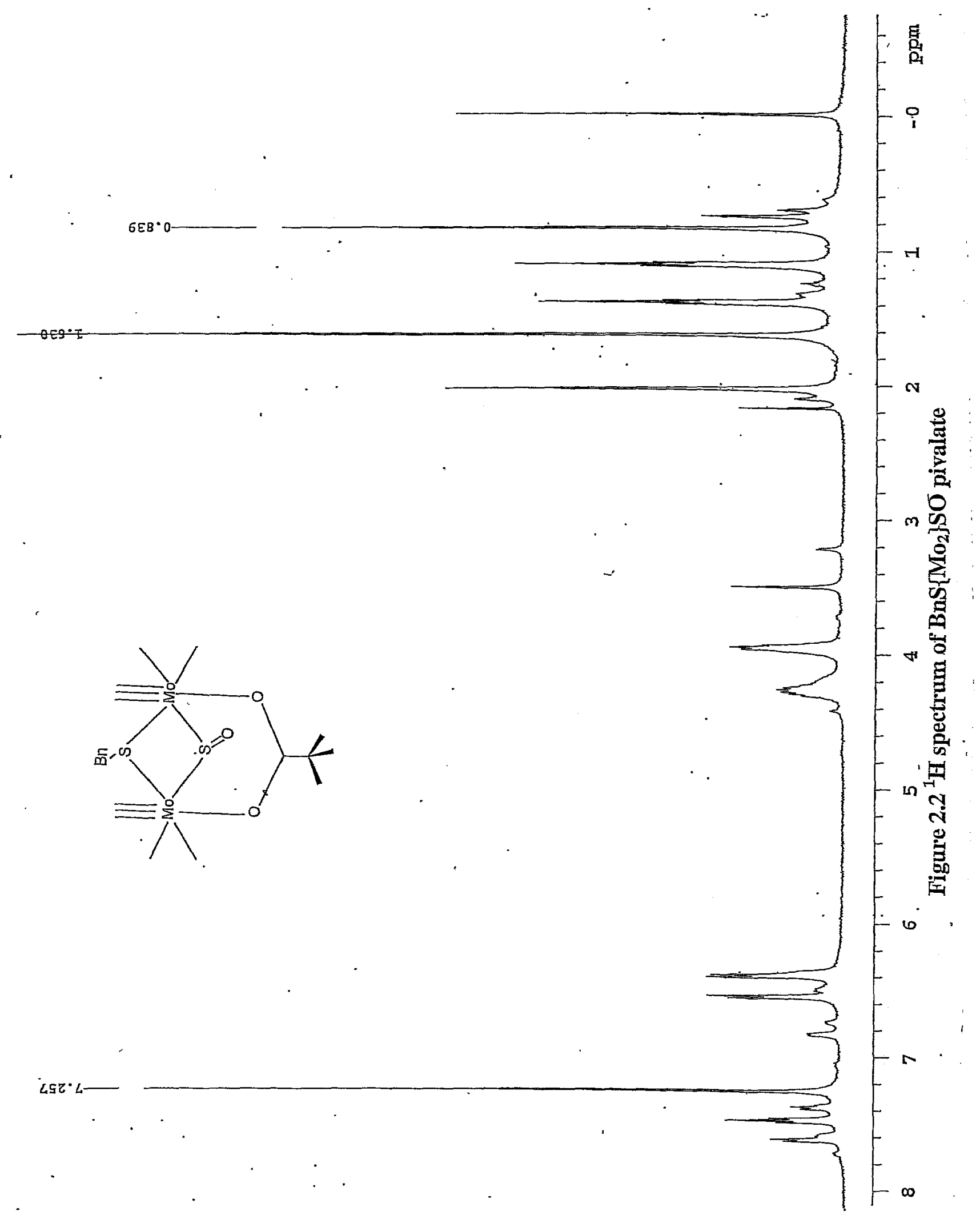


5

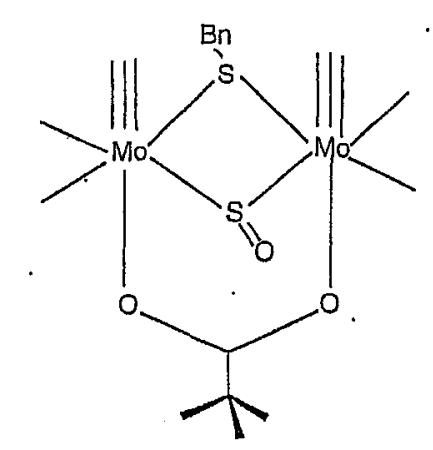

.

$\stackrel{N}{H}$

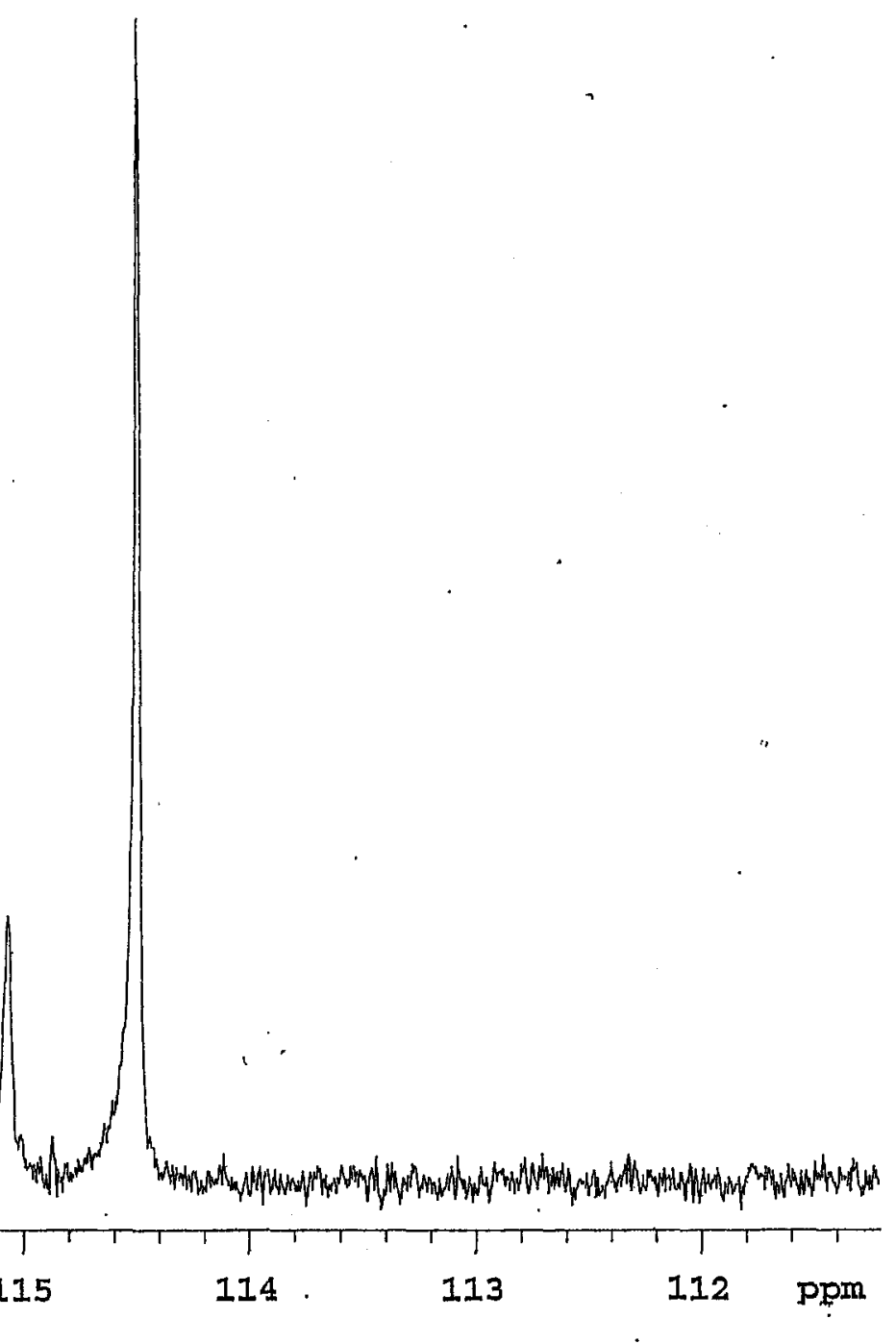

Figure $2.3^{31} \mathrm{P}$ spectrum of $\mathrm{BnS}\left\{\mathrm{Mo}_{2}\right\} \mathrm{SO}$ pivalate 


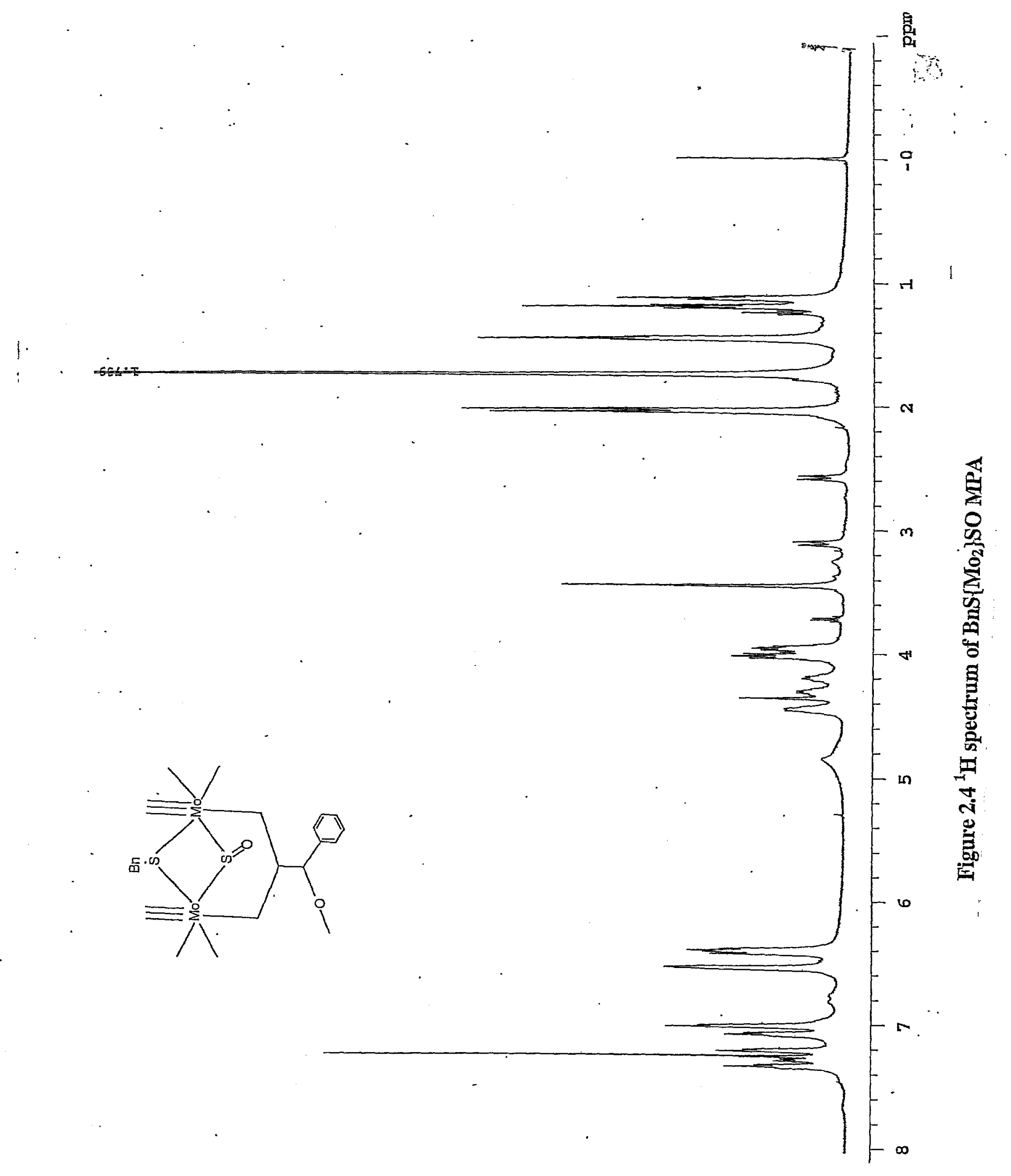


<smiles>[CH]1C=CC1</smiles> 


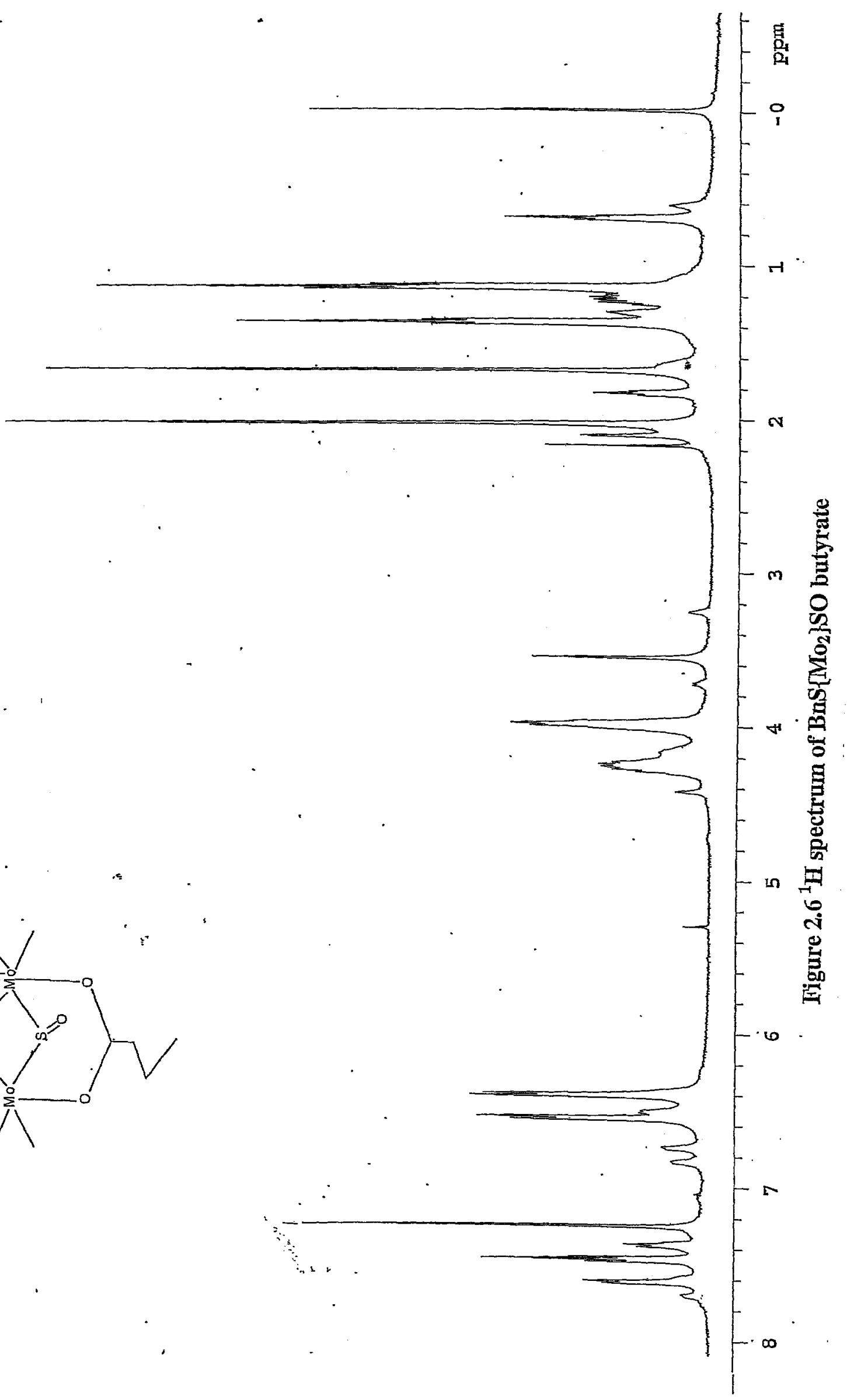




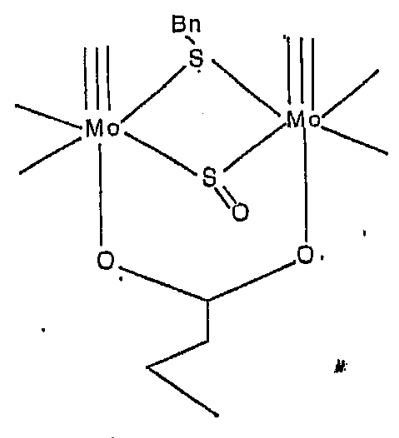

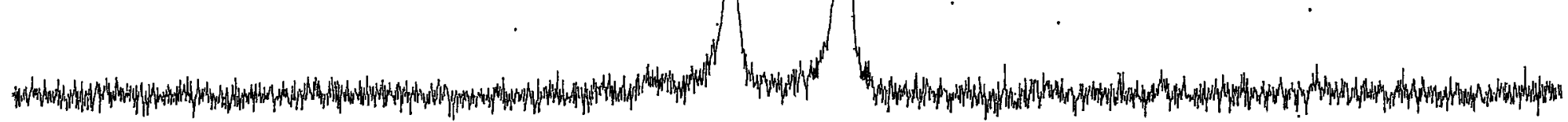

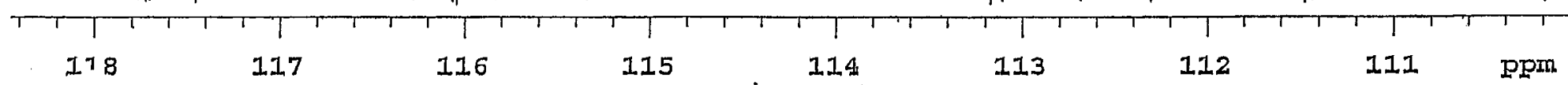

Figure $2.7^{31} \mathrm{P}$ spectrum of $\mathrm{BnS}\left\{\mathrm{Mo}_{2}\right\} \mathrm{SO}$ butyrate 


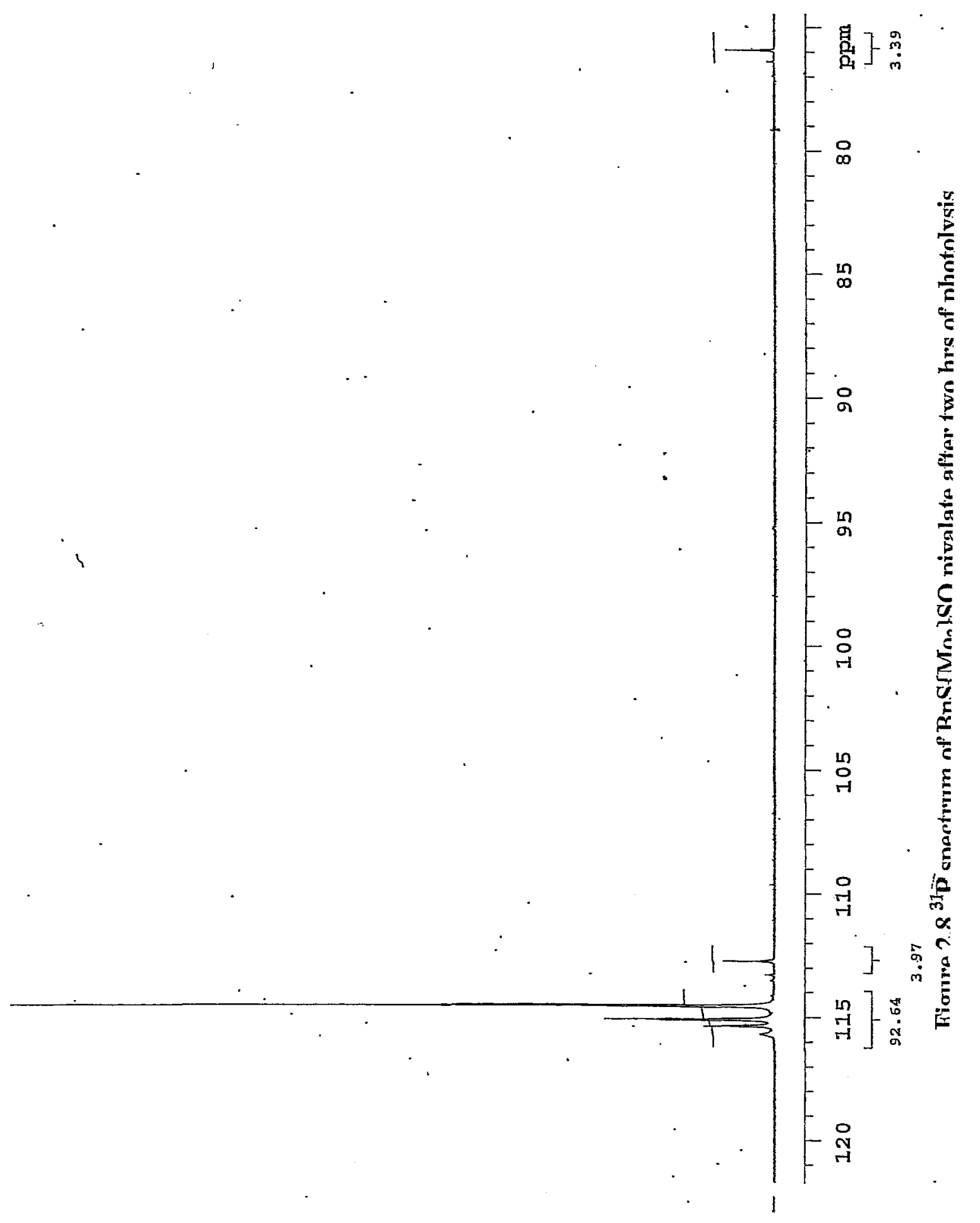




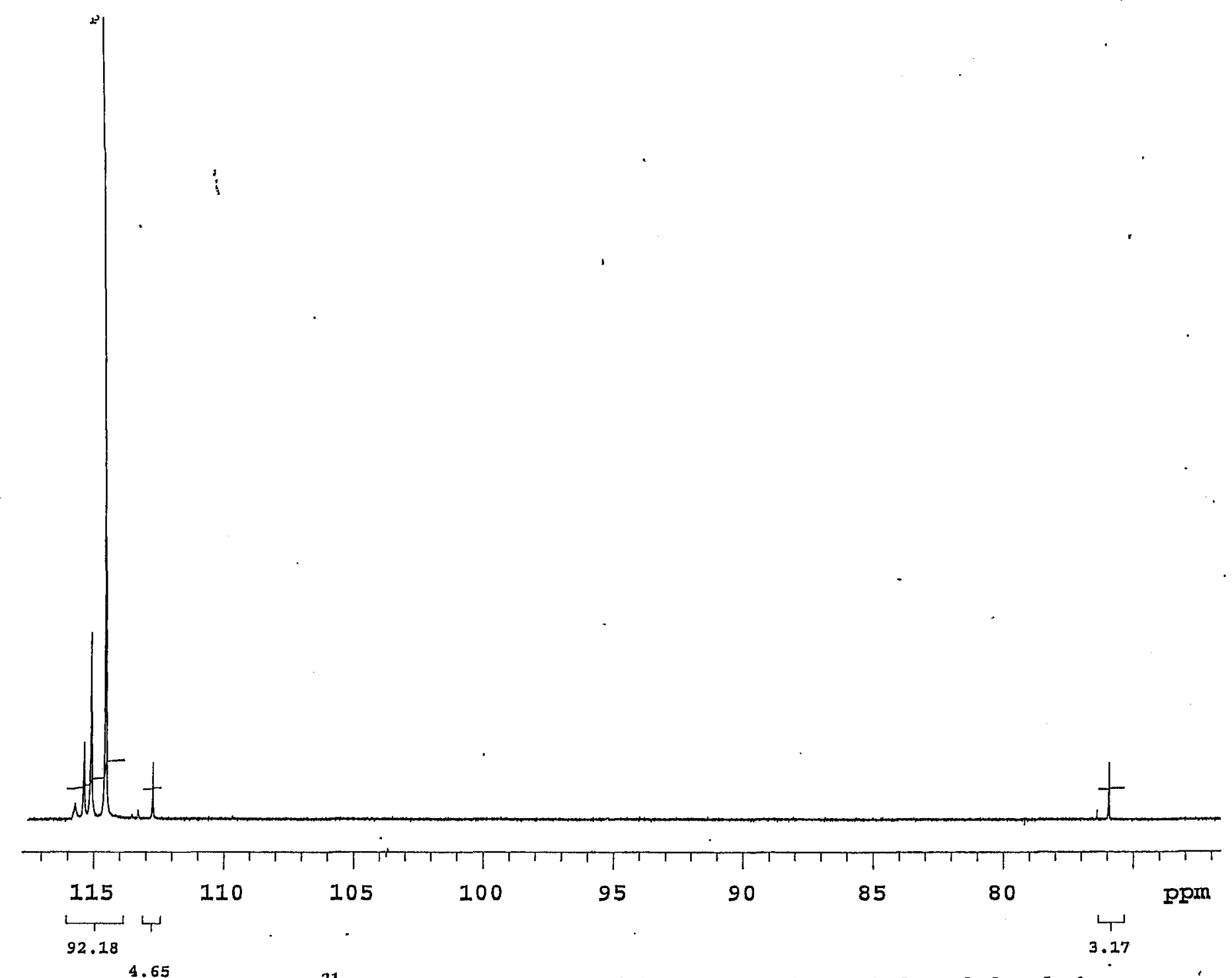

Figure $2.9{ }^{31} \mathrm{P}$ spectrum of $\mathrm{BnS}\left\{\mathrm{Mo}_{2}\right\} \mathrm{SO}$ pivalate after eight hrs of photolysis. 


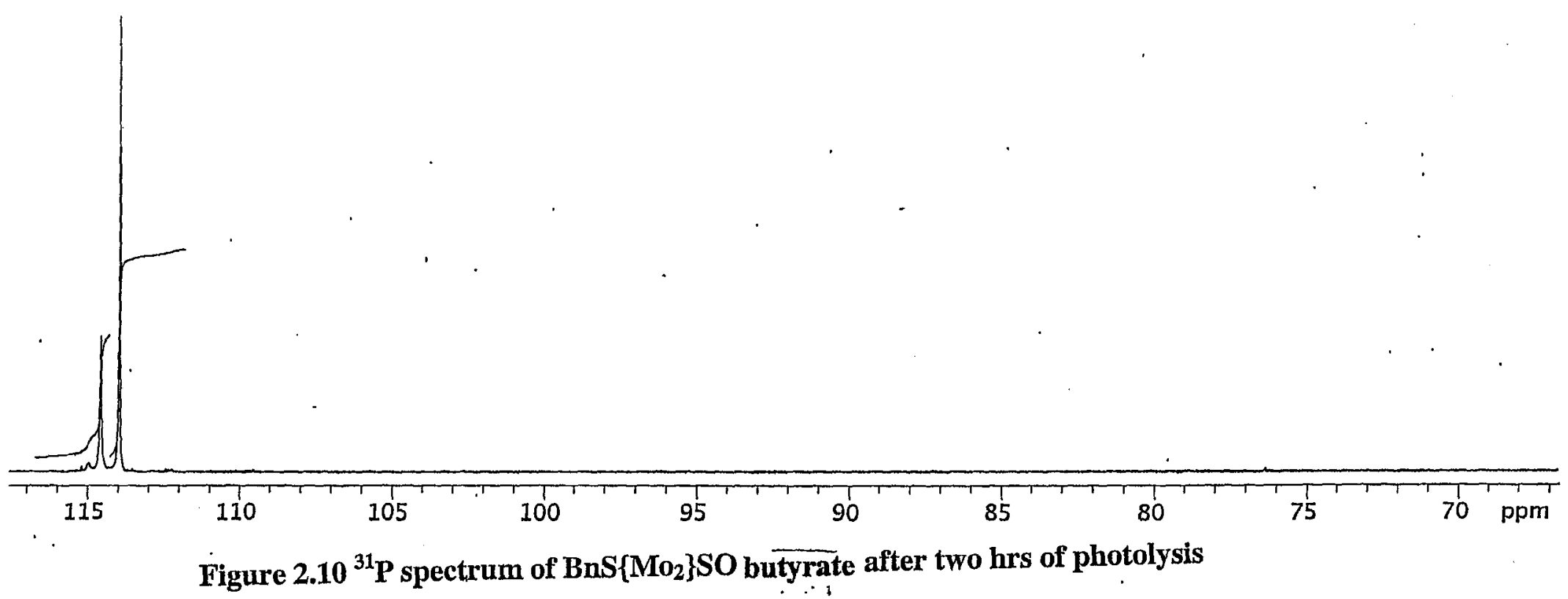


N

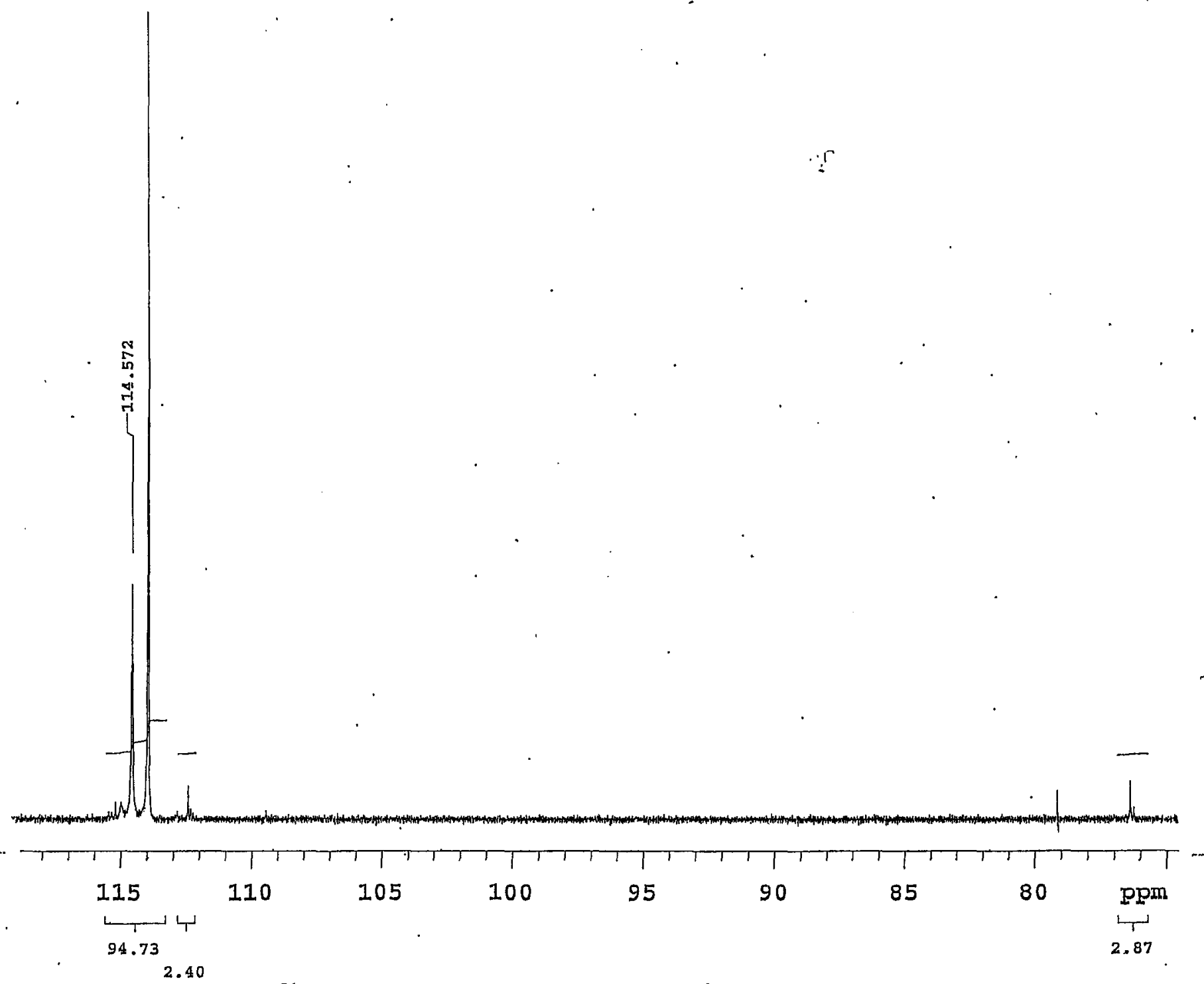

Figure $2.11^{31} \mathrm{P}$ spectrum of $\mathrm{BnS}\left\{\mathrm{Mo}_{2}\right\}$ SO butyrate after eight hrs of photolysis 


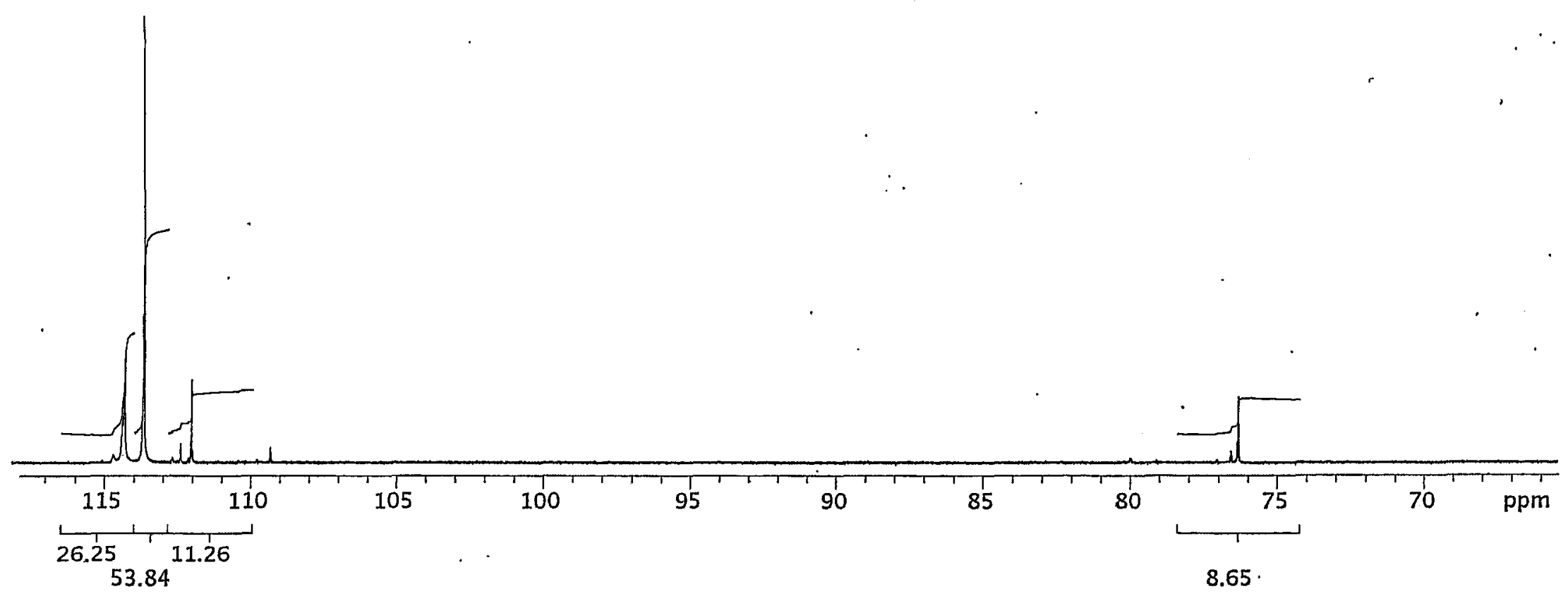

Figure $2.12{ }^{31} \mathrm{P}$ spectrum of $\mathrm{MeS}\left\{\mathrm{Mo}_{2}\right\} \mathrm{SO}$ acetate after two hrs of photolysis 


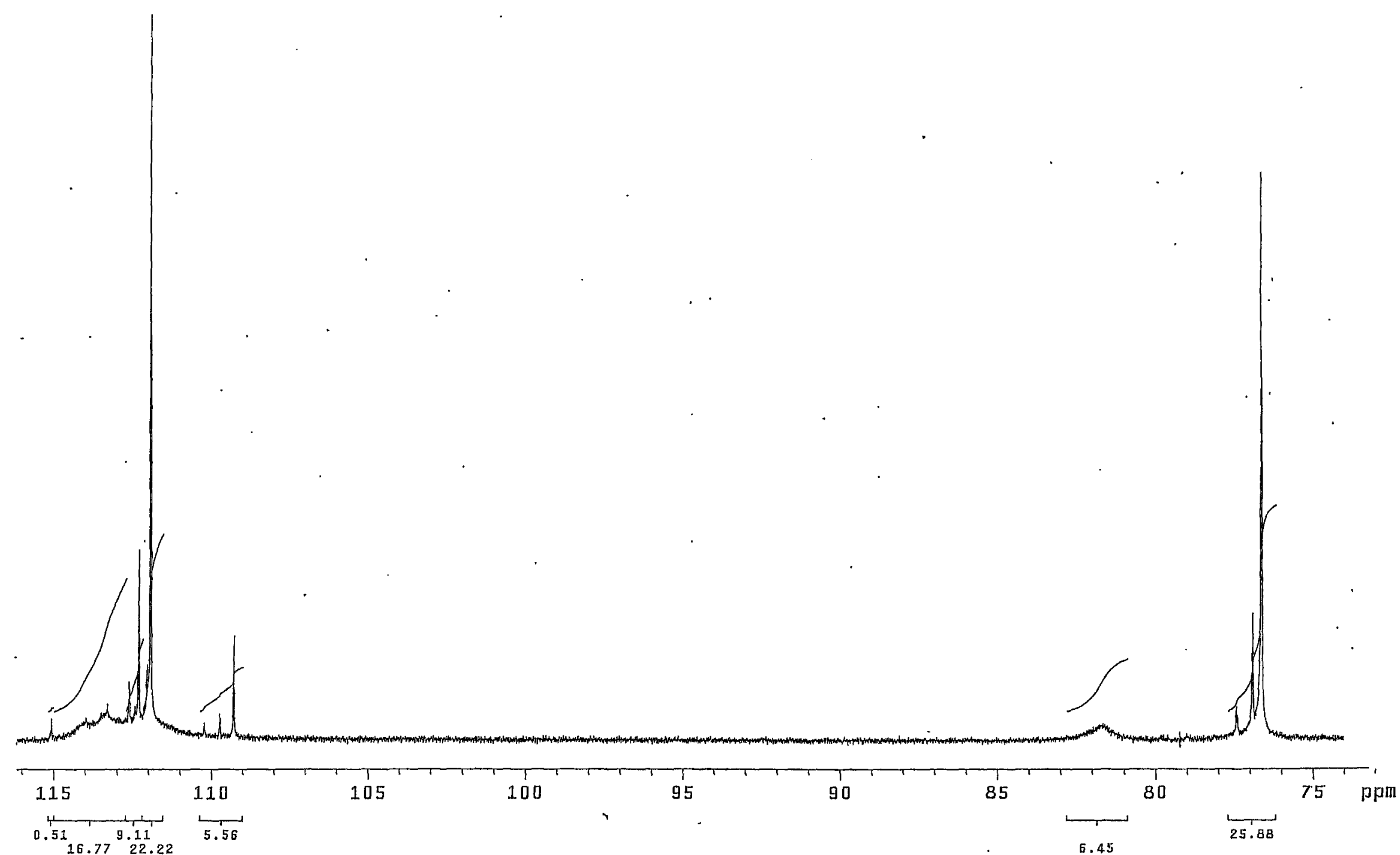

Figure $2.13{ }^{31} \mathrm{P}$ spectrum of MeS\{Mo $\{\mathrm{SO}$ acetate after eight hrs of photolysis 


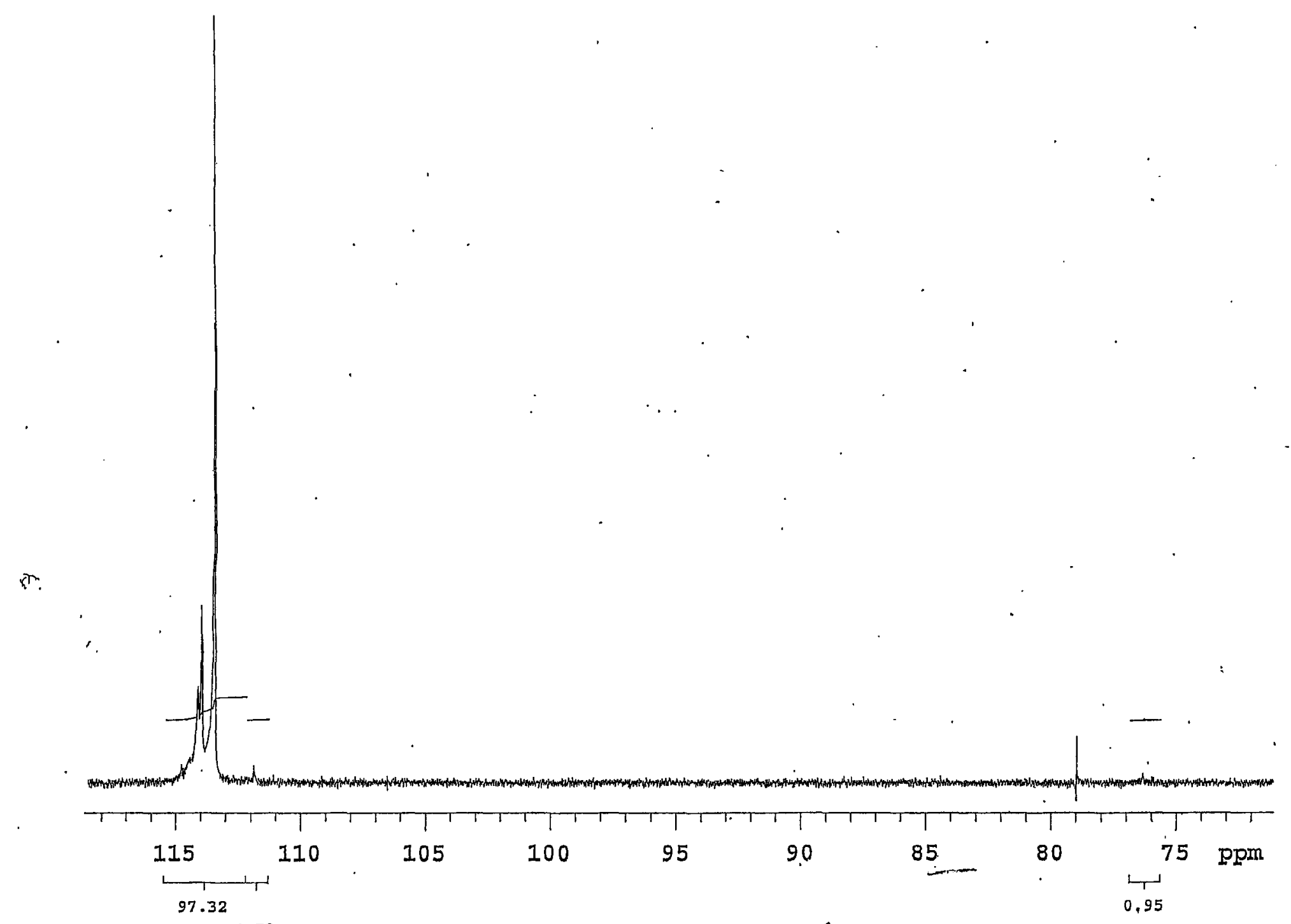

Figure $2.14{ }^{31} \mathrm{P}$ spectrum of $\mathrm{BnS}\left\{\mathrm{Mo}_{2}\right\} \mathrm{SO}$ acetate after two hrs of thermolysis 


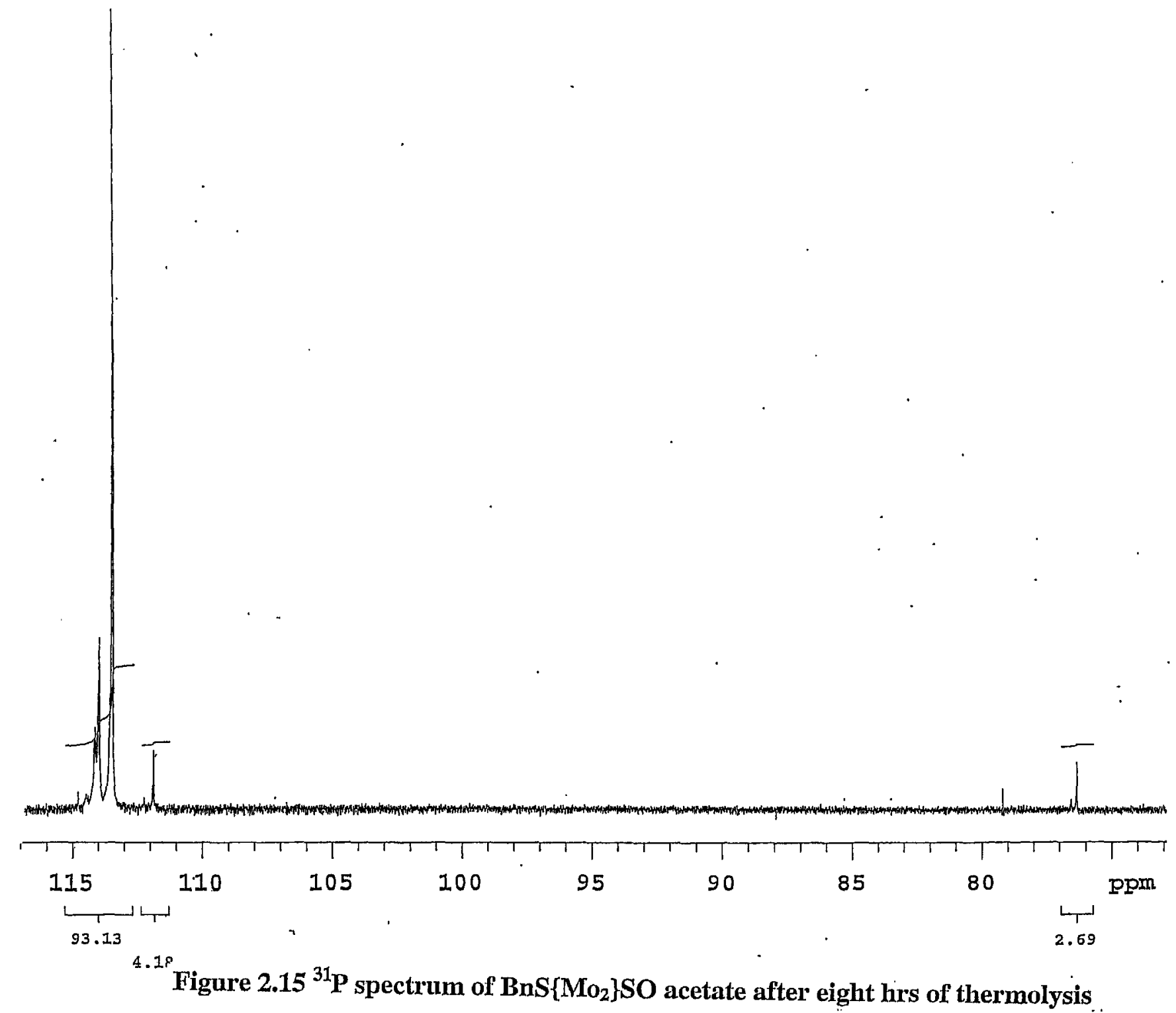




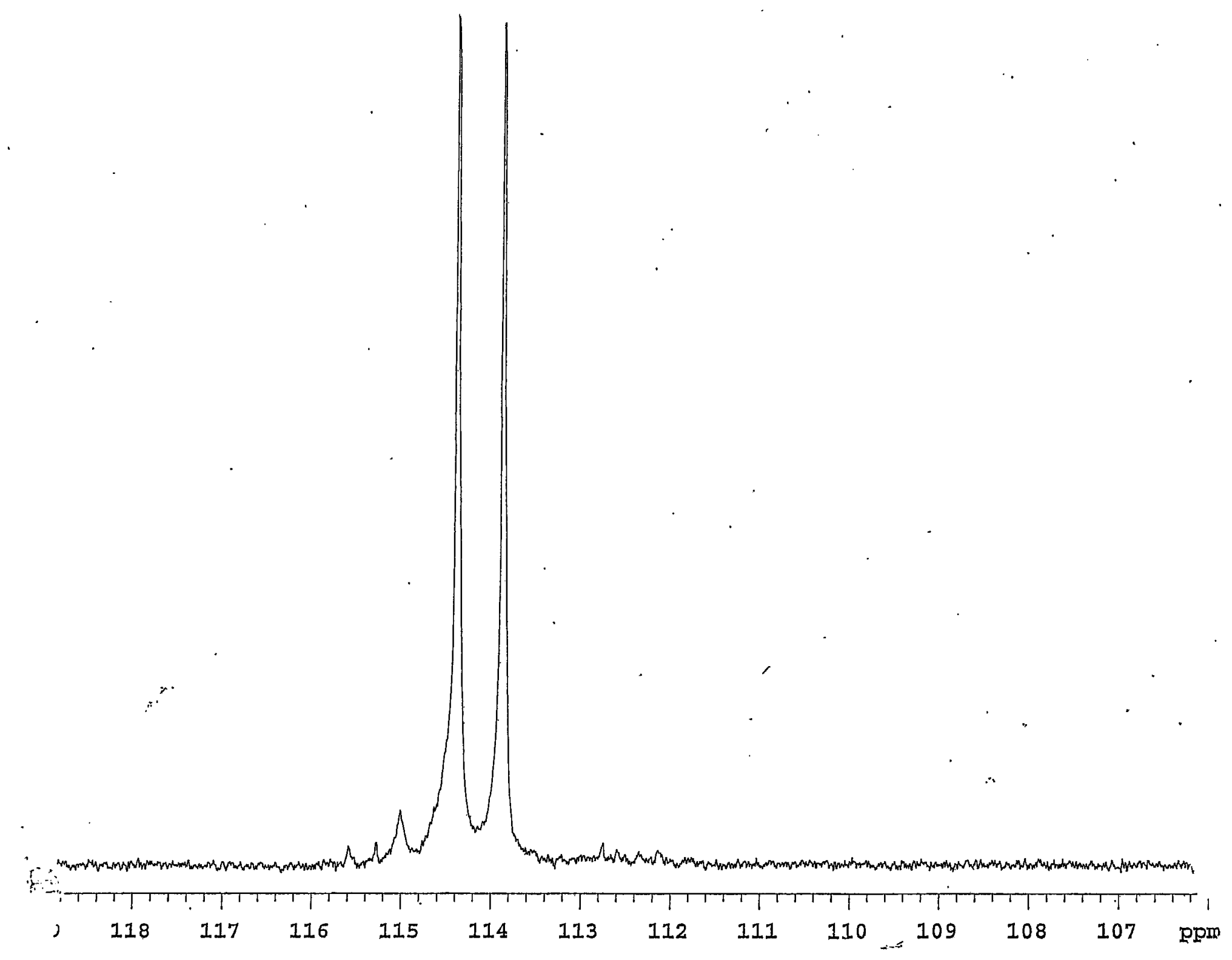

Figure 2.16 ${ }^{31} \mathrm{P}$ spectrum of $\mathrm{BnS}\left\{\mathrm{Mo}_{2}\right\}$ SO methoxyphenylacetate , after two hrs of thermolysis 


$$
\perp
$$




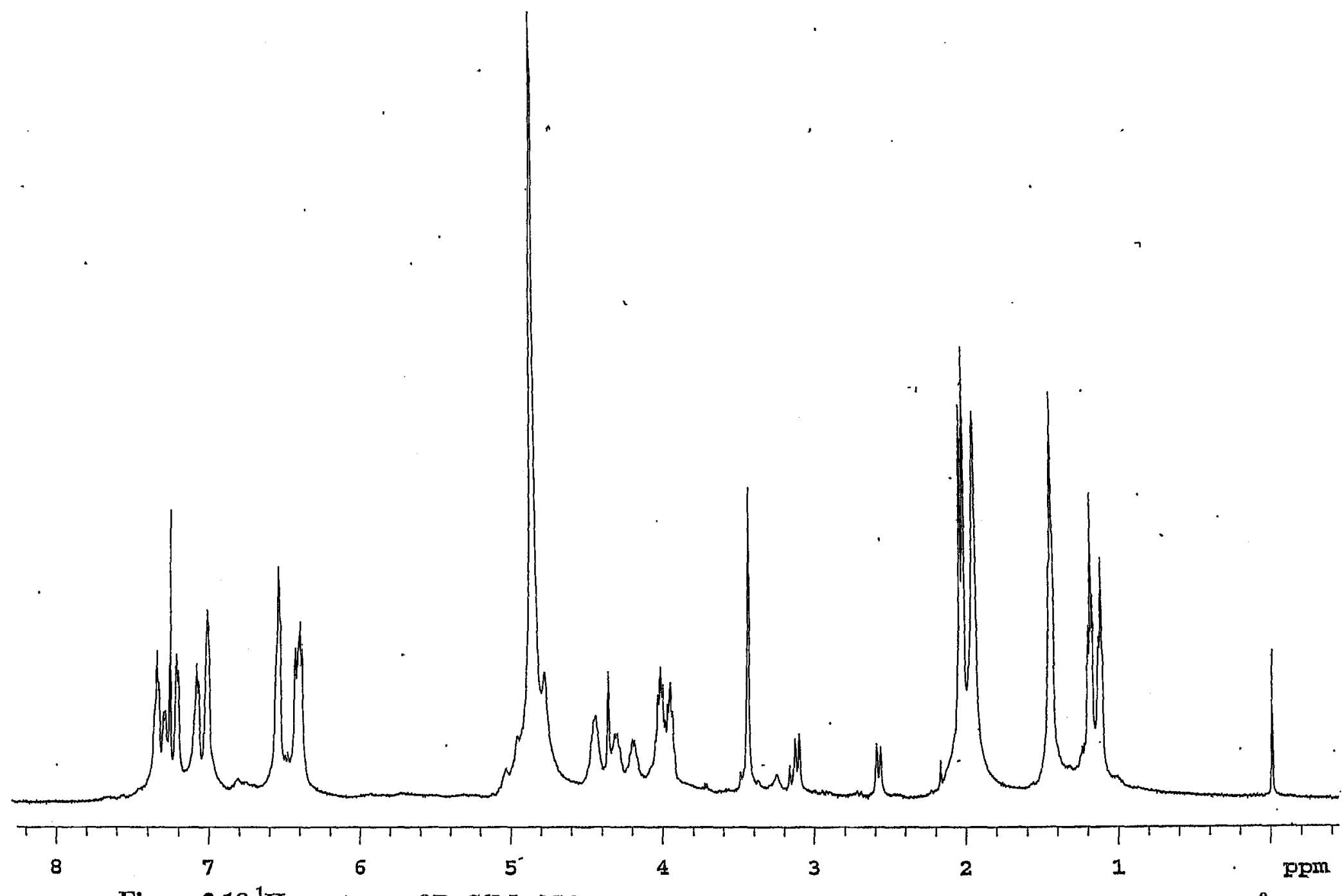

Figure $2.18^{1} \mathrm{H}$ spectrum of $\mathrm{BnS}\left\{\mathrm{Mo}_{2}\right\} \mathrm{SO}$ methoxy phenyl acetate after two hrs of thermolysis at $100^{0} \mathrm{C}$ 


$$
\underline{H}
$$


CHAPTER THREE

\section{SYNTHESIS OF BENZYL THIOPEROXWE BRWGED MOLYBDENUM(V) DIMER $\left[\mathrm{Mo}_{2}(\mathrm{NTO})_{2}\left(\mathrm{~S}_{2} \mathrm{P}(\mathrm{OEt})_{2}\right)_{2}\left(\mu-\mathrm{O}_{2} \mathrm{CMe}\right)(\mu-\mathrm{S})(\mu-\mathrm{SOBn})\right]$}

\subsection{Introduction}

As stated in the previous chapter, the $\mathrm{BnS}\left\{\mathrm{Mo}_{2}\right\} \mathrm{SO}$ compounds are considerably nucleophilic both in the crystalline phase and in solution. As another example, they react with alkyl halides, $\mathrm{RX}$, in polar solvents such as $\left(\mathrm{CD}_{3}\right)_{2} \mathrm{CO}$ to give O-alkylation, eq 3.1, which will lead to the formation of cationic $\left[\mathrm{BnS}\left\{\mathrm{Mo}_{2}\right\} \mathrm{SOR}\right]^{+}$complexes. This alkylation reaction gives a thioperoxide linkage which is definitive by isolation and characterization of these complexes.

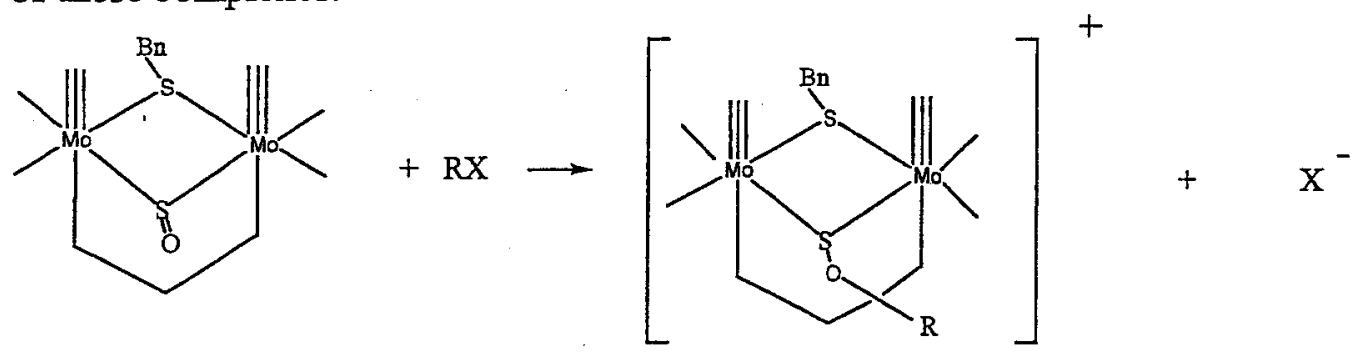

The studies of these compounds, however, are complicated by secondary reactions. The cations that are formed, which are now electrophilic, are vulnerable to nucleophilic attack by the by-products which include the halide anion, $\mathrm{X}$. Prior studies have shown that bis(thiolate-bridged) cations of the general formula $\left[\mathrm{R} S\left\{\mathrm{Mo}_{2}\right\} \mathrm{SR}^{\prime \prime}\right]^{+}$ were activated towards nucleophilic attack. The charge of the cationic complex is delocalized which could be the reason why they are subject to nucleophilic attack in two pathways. This is illustrated for the present complexes in Figure 3.1 by paths $m$ and $n .^{26,31}$ 


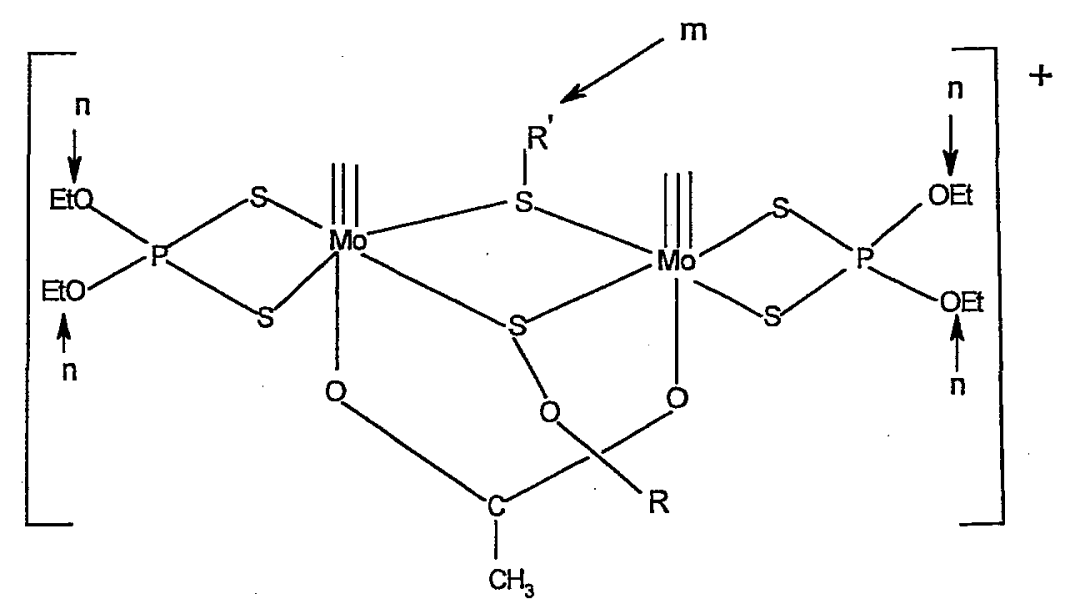

Figure 3.1 Structure of $\mathrm{RS}\left\{\mathrm{Mo}_{2}\right\} \mathrm{SOR}$ ' cation

In path $\mathrm{m}$, the nucleophile attacks the bridge thiolate at the $\alpha$-carbon, breaking the C-S bond and thus producing a sulfide bridge. This offers a neutral compound, $\mathrm{S}\left\{\mathrm{Mo}_{2}\right\} \mathrm{SOR}$.

Previous work on these compounds showed a successful synthesis and isolation of $\mathrm{S}\left\{\mathrm{Mo}_{2}\right\} \mathrm{SOEt}$ and $\mathrm{S}\left\{\mathrm{Mo}_{2}\right\}$ SOMe through a two pot reaction. ${ }^{25,26}$ In these cases, isolation of the intermediate cations required the use of relatively non-nucleophilic counter-ions. Triflate esters were used for the reaction with $\mathrm{BnS}\left\{\mathrm{Mo}_{2}\right\} \mathrm{SO}$ to give $\mathrm{BnS}\left\{\mathrm{Mo}_{2}\right\} \mathrm{SOR}^{+}$ $\mathrm{CF}_{3} \mathrm{SO}^{-}, \mathrm{R}=\mathrm{Me}$ or Et (eq 3.2 and 3.3).

$\mathrm{BnS}\left\{\mathrm{Mo}_{2}\right\} \mathrm{SO}+\mathrm{CF}_{3} \mathrm{SO}_{3} \mathrm{R} \longrightarrow \mathrm{BnS}\left\{\mathrm{Mo}_{2}\right\} \mathrm{SOR}^{+} \mathrm{CF}_{3} \mathrm{SO}_{3}^{-}$

$\mathrm{BnS}\left\{\mathrm{Mo}_{2}\right\} \mathrm{SOR}^{+} \mathrm{CF}_{3} \mathrm{SO}_{3}^{-}+\mathrm{PPNT}^{+} \longrightarrow \mathrm{S}\left\{\mathrm{Mo}_{2}\right\} \mathrm{SOR}+\mathrm{PPN}^{+} \mathrm{CF}_{3} \mathrm{SO}_{3}{ }^{-}+\mathrm{BnI}$

$\mathrm{S}\left\{\mathrm{Mo}_{2}\right\} \mathrm{SOR}(\mathrm{R}=\mathrm{Me}, \mathrm{Et})$ were prepared from the debenzylation of the cations $\mathrm{BnS}\left\{\mathrm{MO}_{2}\right\} \mathrm{SOR}^{+}$, eq 3.3. Various nucleophiles were examined for enhancing the 
selectivity of $\mathrm{S}\left\{\mathrm{Mo}_{2}\right\} \mathrm{SOR}$ over de-esterification, path $\mathrm{n}$. PPN'T proved to be the most useful reagent for synthetic purposes.

In the competing path $\mathrm{n}$, there is a nucleophilic attack on either dithiophosphate ligand at either of the ethyl groups, cleaving the $\mathrm{C}-\mathrm{O}$ bond; this is irreversible deesterification of a dithiophosphate ligand within the cationic complex to give $\left[\mathrm{Mo}_{2}(\mathrm{NTo})_{2}\left(\mathrm{~S}_{2} \mathrm{P}=\mathrm{O}(\mathrm{OEt})\right)\left(\mathrm{S}_{2} \mathrm{P}(\mathrm{OEt})_{2}\right)\left(\mu-\mathrm{O}_{2} \mathrm{CMe}\right)(\mu-\mathrm{SBn})(\mu-\mathrm{SOR})\right]$, designated $\mathrm{BnS}\left\{\mathrm{Mo}_{2}(\mathrm{P}=\mathrm{O})\right\} \mathrm{SOR}$. The product contains a dianionic, monoethyl, dithiophosphate ligand, $(\mathrm{EtO}) \mathrm{P}(=\mathrm{O}) \mathrm{S}_{2}{ }^{2}$.

In the present work, $\mathrm{S}\left\{\mathrm{Mo}_{2}\right\} \mathrm{SOBn}$ was synthesized from $\mathrm{BnS}\left\{\mathrm{Mo}_{2}\right\} \mathrm{SO}$ using $\mathrm{BnBr}$ through a one pot process instead of the two pot process shown by eq 3.2 and 3.3. $\mathrm{S}\left\{\mathrm{Mo}_{2}\right\} \mathrm{SOBn}$ is synthesized through the alkylation of $\mathrm{BnS}\left\{\mathrm{Mo}_{2}\right\} \mathrm{SO}$ by $\mathrm{BnBr}$ forming the intermediate cation $\left[\mathrm{BnS}\left\{\mathrm{Mo}_{2}\right\} \mathrm{SOBn}\right]^{+}$, which then either undergoes debenzylation or de-esterification. The proposed sequence is shown in Scheme 3.1.

\subsection{Experimental Section}

The synthesis of $\mathrm{BnS}\left\{\mathrm{Mo}_{2}\right\} \mathrm{SO}$ followed that given in Chapter 2 .

\section{$\left[\mathrm{Mo}_{2}(\mathrm{NTo})_{2}\left(\mathrm{~S}_{2} \mathrm{P}(\mathrm{OEt})_{2}\right)_{2}\left(\mu-\mathrm{O}_{2} \mathrm{CMe}\right)(\mu-\mathrm{S})(\mu-\mathrm{SOBn})\right], \mathrm{S}\left\{\mathrm{Mo}_{2}\right\} \mathrm{SOBn}$.}

To a stirring solution of $\mathrm{BnS}\left\{\mathrm{Mo}_{2}\right\} \mathrm{SO}(0.0996 \mathrm{~g}, 0.0993 \mathrm{mmol})$ in $2 \mathrm{~mL} \mathrm{Me} 2 \mathrm{CO}$ was added $\mathrm{BnBr}(47 \mu \mathrm{L}, 0.40 \mathrm{mmol})$. The solution was stirred for $2.9 \mathrm{~h}$, after which the product was precipitated with 1:1 EtOH: $\mathrm{H}_{2} \mathrm{O}(6 \mathrm{~mL})$. The precipitate was filtered and washed with 1:1 EtOH: $\mathrm{H}_{2} \mathrm{O}$ and then suction dried to give a red/orange powder $(0.0570$ g; 57\%). ${ }^{1} \mathrm{H}$ NMR in Figure 3.3 shows (in ppm): 7.46 t, 7.29-7.39 m, Bn-H; (6.56 d), 6.54 d, $6.45 \mathrm{~d},(6.32 \mathrm{~d}), \mathrm{To}-\mathrm{H} ;(5.22 \mathrm{~s}), 5.13 \mathrm{~s}, \mathrm{Bn}-\mathrm{CH}_{2} ; 4.18 \mathrm{~m}, 4.09 \mathrm{~m}, \mathrm{POCH}_{2} ; 2.08 \mathrm{~s},(2.06$ s), To- $\mathrm{CH}_{3} ; 1.32 \mathrm{t},(1.23 \mathrm{t}), 1.22 \mathrm{t}, \mathrm{POCCH}_{3} ;(1.21 \mathrm{~s}), 1.04 \mathrm{~s}, \mathrm{O}_{2} \mathrm{CCH}_{3}$. Invertomer ratio: 


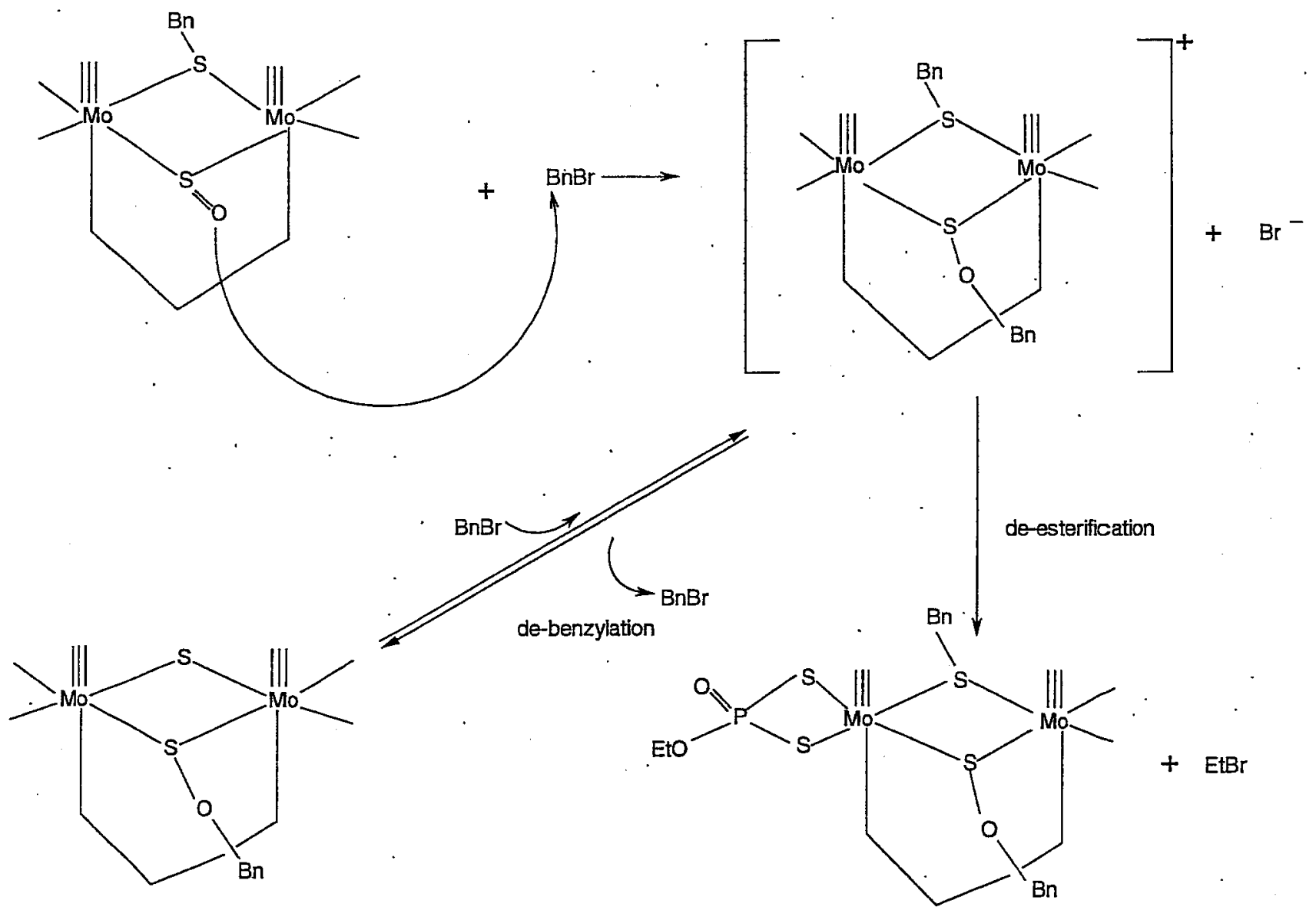

Scheme 3.1. Proposed mechanism of $\mathrm{S}\left\{\mathrm{Mo}_{2}\right\} \mathrm{SOBn}$ formation 
3.9. ${ }^{31} \mathrm{P}$ NMR in Figure 3.4 gave the following results (ppm): 115.0, (114.9).

$\left[\mathrm{Mo}_{4}(\mathrm{NTO})_{4}\left(\mathrm{~S}_{2} \mathrm{P}(\mathrm{OEt})_{2}\right)_{4} \mathrm{~S}_{3}\left(\mathrm{O}_{2} \mathrm{CMe}\right)_{2}(\mathrm{SOBn})\right]\left(\mathrm{BF}_{4}\right),\left[\mathrm{S}\left\{\mathrm{Mo}_{2}\right\} \mathrm{SS}_{2}\left\{\mathrm{Mo}_{2}\right\} \mathrm{SOBn}_{3}\right] \mathrm{BF}_{4}$

The reaction was carried out in subdued, indirect light. A solution of

$\mathrm{S}\left\{\mathrm{Mo}_{2}\right\} \mathrm{SOBn}(0.0755 \mathrm{~g}, 0.0753 \mathrm{mmol})$ in $0.8 \mathrm{~mL}$ of $\mathrm{Me}_{2} \mathrm{CO}$ was treated with $48 \% \mathrm{HBF}_{4}$

$(5.0 \mu \mathrm{L}, 0.038 \mathrm{mmol})$. The solution was stirred for 6 hours and rotavapped, and the residue was dissolved in minimum $\mathrm{CH}_{2} \mathrm{Cl}_{2}$. The solid was then precipitated with 1:1 petroleum ether: $\mathrm{Et}_{2} \mathrm{O}(2.4 \mathrm{~mL})$. The precipitate was filtered and washed with 1:1 petroleum ether: $\mathrm{Et}_{2} \mathrm{O}$ and then dried $(0.02241 \mathrm{~g}, 30 \%)$. The main product, [S $\left.\left\{\mathrm{MO}_{2}\right\} \mathrm{SS}\left\{\mathrm{Mo}_{2}\right\} \mathrm{SOBn}\right] \mathrm{BF}_{4}$ was identified by comparison with the NMR data of [S $\left.\left\{\mathrm{Mo}_{2}\right\} \mathrm{SS}\left\{\mathrm{Mo}_{2}\right\} \mathrm{SOCH}_{3}\right]^{+} \cdot{ }^{25}{ }^{1} \mathrm{H}$ NMR on Figure 3.5 gave the following (ppm): $7.46 \mathrm{~d}$, 7.29-7.39 m, BnH; 7.05 d, 6.90 d, 6.48 d, 6.47 d, ToH; (5.55 s), (5.53 s), 5.49 s, $\mathrm{BnCH}_{2}$; 4.00-4.30 m $\mathrm{POCH}_{2} ;(2.21 \mathrm{~s}),(2.16 \mathrm{~s}), 2.14 \mathrm{~s}, 2.11 \mathrm{~s}$, To- $\mathrm{CH}_{3} ; 1.18 \mathrm{~s},(1.15 \mathrm{~s}),(1.02 \mathrm{~s})$, $\mathrm{O}_{2} \mathrm{CCH}_{3} ; 1.34 \mathrm{t}, 1.30 \mathrm{t}, 1.23 \mathrm{t}, \mathrm{POCCH}_{3} .{ }^{31} \mathrm{P}$ NMR (in ppm) in Figure 3.6 shows the following: 114.0, (113.9), (109.9),109.2.

Crystallography. A crystal of $\left[\mathrm{S}\left\{\mathrm{Mo}_{2}\right\} \mathrm{SS}\left\{\mathrm{Mo}_{2}\right\} \mathrm{SOBn}\right] \mathrm{BF}_{4}$ was grown by the following procedure: Approximately $6 \mathrm{mg}\left[\mathrm{S}\left\{\mathrm{Mo}_{2}\right\} \mathrm{SS}\left\{\mathrm{Mo}_{2}\right\} \mathrm{SOBn}\right] \mathrm{BF} F_{4}$ were mixed with benzene. $\mathrm{CHCl}_{3}$ was added until it dissolved and this was allowed to evaporate open to air over several days. Blocks of crystals were collected for X-ray crystallography. Data collection and structure solution were conducted by Dr. M.S. Mashuta, University of Louisville. Crystal data and experimental details are given in Tables 3.1-3.6. An ORTEP view is in Figure 3.8.

\subsection{Results}

$\mathrm{BnS}\left\{\mathrm{Mo}_{2}\right\} \mathrm{SO}+\mathrm{BnBr} \longrightarrow\left[\mathrm{BnS}\left\{\mathrm{Mo}_{2}\right\} \mathrm{SOBn}\right]^{+}+\mathrm{Br}^{-} \longrightarrow \mathrm{S}\left\{\mathrm{Mo}_{2}\right\} \mathrm{SOBn}+\mathrm{BnBr}$ 
The reaction of eq 3.4 shows that the oxygen bonded to the sulfur bridge is nucleophilic and attacks the benzyl carbon of $\mathrm{BnBr}$ breaking the $\mathrm{C}-\mathrm{Br}$ bond. The intermediate cation then undergoes either of two possible reaction pathways through de-benzylation or deesterification.

As an example, the reaction of $\mathrm{BnS}\left\{\mathrm{Mo}_{2}\right\} \mathrm{SO}$ with four equivalents of benzyl bromide after $3 \mathrm{~h}$ in $\mathrm{Me}_{2} \mathrm{CO}$ showed the presence of the cation, $\left[\mathrm{BnS}\left\{\mathrm{Mo}_{2}\right\} \mathrm{SOBn}\right]^{+}$, the de-ethylation product, $\left[\mathrm{BnS}\left\{\mathrm{Mo}_{2}(\mathrm{P}=\mathrm{O})\right\} \mathrm{SOBn}\right]$ and the de-benzylation product, $\mathrm{S}\left\{\mathrm{Mo}_{2}\right\} \mathrm{SOBn}$. There was no evidence of reactant, $\mathrm{BnS}\left\{\mathrm{MO}_{2}\right\} \mathrm{SO}$, after this time frame. This is supported by ${ }^{31} \mathrm{P} N M R$ in Figure 3.9. The presence of $\mathrm{BnS}\left\{\mathrm{Mo}_{2}(\mathrm{P}=0)\right\} \mathrm{SOBn}$ is shown in the ${ }^{31} \mathrm{P} N M R$ spectrum by peaks at $72-74 \mathrm{ppm}$ and 111-113 ppm. The product $\mathrm{S}\left\{\mathrm{Mo}_{2}\right\} \mathrm{SOBn}$ is at $115.8 \mathrm{ppm}$ and the cation $\left[\mathrm{BnS}\left\{\mathrm{Mo}_{2}\right\} \mathrm{SOBn}\right]^{+}$is at $112.6 \mathrm{ppm}$. The $\mathrm{BnS}\left\{\mathrm{Mo}_{2}(\mathrm{P}=\mathrm{O})\right\} \mathrm{SOBn}$ decomposition product did not precipitate from 1:1 EtOH: $\mathrm{H}_{2} \mathrm{O}$.

\section{$\left[\mathrm{S}\left\{\mathrm{Mo}_{2}\right\} \mathrm{SS}_{\{}\left\{\mathrm{Mo}_{2}\right\} \mathrm{SOBn}_{\mathrm{B}} \mathrm{BF}_{4}\right.$}

$2 \mathrm{~S}\left\{\mathrm{Mo}_{2}\right\} \mathrm{SOBn}+\mathrm{HBF}_{4} \longrightarrow\left[\mathrm{S}\left\{\mathrm{Mo}_{2}\right\} \mathrm{SS}\left\{\mathrm{Mo}_{2}\right\} \mathrm{SOBn}\right] \mathrm{BF}_{4}+\mathrm{BnOH}$

Different inorganic acids were tried to see how they reacted with $\mathrm{S}\left\{\mathrm{Mo}_{2}\right\} \mathrm{SOBn}$. The acids included $\mathrm{HCl}, \mathrm{H}_{2} \mathrm{SO}_{4}, \mathrm{CF}_{3} \mathrm{SO}_{3} \mathrm{H}$ and $\mathrm{HBF}_{4}$. All except $\mathrm{HBF}_{4}$ showed that the acid anion was substituting the acetate bridging group. The reaction of excess $\mathrm{HBF}_{4}$ with $\mathrm{S}\left\{\mathrm{Mo}_{2}\right\} \mathrm{SOBn}$ was done in subdued, indirect light, as noted previously. The site of protonation could either be at $\mathrm{S}$ or $\mathrm{O}$ due to basicity of both atoms. Protonation at oxygen, being more reactive, will lead to the $\mathrm{S}\left\{\mathrm{Mo}_{2}\right\} \mathrm{SOH}(\mathrm{Bn})^{+}$intermediate cation. The intermediate, $\mathrm{S}\left\{\mathrm{MO}_{2}\right\} \mathrm{SOH}(\mathrm{Bn})^{+}$cation will dissociate to generate the cation, $\left[\mathrm{S}\left\{\mathrm{MO}_{2}\right\} \mathrm{S}^{+}\right.$ and $\mathrm{BnOH}$. The production of the $\left[\mathrm{S}\left\{\mathrm{Mo}_{2}\right\} \mathrm{S}\right]^{+}$intermediate cation would then constitute an extra step to the whole process (Scheme 3.2). 
The ${ }^{1} \mathrm{H}$ NMR spectrum in Figure 3.5 showed the presence of the bis-dimer product $\left[\mathrm{S}\left\{\mathrm{Mo}_{2}\right\} \mathrm{SS}\left\{\mathrm{Mo}_{2}\right\} \mathrm{SOBn}\right]^{+}$as shown by two singlets for $\mathrm{To}-\mathrm{CH}_{3}$ from both dimers at $2.14 \mathrm{ppm}$ and at $2.11 \mathrm{ppm}$; this evidence is further supported by the presence of the $\mathrm{Bn}-\mathrm{CH}_{2}$ in one dimer at $5.49 \mathrm{ppm}$. The presence of a dimer of dimers is additionally supported by the presence of a singlet of the $\mathrm{O}_{2} \mathrm{CCH}_{3}$ bridge which is at $1.20 \mathrm{ppm}$. At least four sets of multiplets are visible in the region $4.00-4.45 \mathrm{ppm}$ which corresponds to $\mathrm{POCH}_{2}$. Figure 3.6 shows the ${ }^{31} \mathrm{P} \mathrm{NMR}$ spectrum of $\left[\mathrm{S}\left\{\mathrm{MO}_{2}\right\} \mathrm{SS}\left\{\mathrm{Mo}_{2}\right\} \mathrm{SOBn}\right]^{+}$with peaks at $114.0,(113.9),(109.9)$ and $109.2 \mathrm{ppm}$.

[S $\left.\left\{\mathrm{Mo}_{2}\right\} \mathrm{SS}\left\{\mathrm{Mo}_{2}\right\} \mathrm{SOBn}\right] \mathrm{BF}_{4}$ is photosensitive. To demonstrate this, approximately $30 \mathrm{mg}$ of [ $\left.\mathrm{S}\left\{\mathrm{Mo}_{2}\right\} \mathrm{SS}\left\{\mathrm{Mo}_{2}\right\} \mathrm{SOBn}_{3}\right] \mathrm{BF}_{4}$ in $\mathrm{CDCl}_{3}$ was photolysed for $2 \mathrm{hrs}$ with visible light. The NMR spectrum in Figure 3.7 shows the photolysed $\left.\mathrm{S}\left\{\mathrm{Mo}_{2}\right\} \mathrm{SS}\left\{\mathrm{Mo}_{2}\right\} \mathrm{SOBn}\right]^{+}$products at $115.0 \mathrm{ppm}$ and $115.1 \mathrm{ppm}$, and at $108.5 \mathrm{ppm}$ and $107.9 \mathrm{ppm}$. The ${ }^{31} \mathrm{P}$ NMR results suggest that the $115.1 \mathrm{ppm}$ peak corresponded to neutral S $\left\{\mathrm{Mo}_{2}\right\} \mathrm{SS}\left\{\mathrm{Mo}_{2}\right\} \mathrm{S}$ and the $108.9 \mathrm{ppm}$ peak would be tentatively assigned to cationic $\left[\mathrm{BnOS}\left\{\mathrm{Mo}_{2}\right\} \mathrm{SS}\left\{\mathrm{Mo}_{2}\right\} \mathrm{SOBn}\right]^{2+}$. (Scheme 3.3)

The crystal structure of $\left[\mathrm{S}\left\{\mathrm{Mo}_{2}\right\} \mathrm{SS}\left\{\mathrm{Mo}_{2}\right\} \mathrm{SOBn}\right]^{+}$proved the presence of two different dimers co-joined by an S-S bridge. The crystal data, experimental details, selected positional parameters, bond lengths and angles can be found in Tables 3.1 to 3.6 at the end of this chapter. The bis-dimer, $\left[\mathrm{S}\left\{\mathrm{Mo}_{2}\right\} \mathrm{SS}\left\{\mathrm{Mo}_{2}\right\} \mathrm{SOBn}\right]^{+}$consists of two structurally different dimers linked by the disulfide linkage which makes it unusual as it comprises both a neutral dimer, [S $\left.\left\{\mathrm{Mo}_{2}\right\} \mathrm{S}-\right]$ and a cationic dimer, $\left[-\mathrm{S}\left\{\mathrm{Mo}_{2}\right\} \mathrm{SOBn}\right]^{+}$. Due to the functionalized sulfur bridges, there are up to eight possible invertomers for the final products as shown in Figure 3.10. The cation portion, $\left[-\mathrm{S}\left\{\mathrm{Mo}_{2}\right\} \mathrm{SOBn}\right]^{+}$, was compared with the cation, $\left[\mathrm{BnS}\left\{\mathrm{Mo}_{2}\right\} \mathrm{SOEt}\right]^{+}$which had been characterized by prior 
researchers ${ }^{26}$, while the neutral portion of $\left.\mathrm{S}\left\{\mathrm{Mo}_{2}\right\} \mathrm{SS}\left\{\mathrm{Mo}_{2}\right\} \mathrm{SOBn}\right]^{+}$was compared to $\mathrm{S}\left\{\mathrm{Mo}_{2}\right\} \mathrm{SS}\left\{\mathrm{MO}_{2}\right\} \mathrm{S}$ which also had been characterized by prior researchers. ${ }^{32}$ For easier comparison the cation potion of the bis-dimer will be represented as [-S $\left.\left\{\mathrm{Mo}_{2}\right\} \mathrm{SOBn}\right]^{+}$, while the neutral portion will be represented as $\left[\mathrm{S}\left\{\mathrm{Mo}_{2}\right\} \mathrm{S}-\right]$. Parameters that were compared include bond lengths and bond angles. Furthermore, to make the comparison easier between structures, some atoms of the original ORTEP of $\left[\mathrm{BnS}\left\{\mathrm{Mo}_{2}\right\} \mathrm{SOEt}\right]^{+}$and $\mathrm{S}\left\{\mathrm{Mo}_{2}\right\} \mathrm{SS}\left\{\mathrm{Mo}_{2}\right\} \mathrm{S}$ have been renumbered so that they would correspond to the numbering system used for $\left[\mathrm{S}\left\{\mathrm{Mo}_{2}\right\} \mathrm{SS}\left\{\mathrm{Mo}_{2}\right\} \mathrm{SOBn}\right]^{+}$.

The general feature of these three compounds is as follows. Looking at the $\mathrm{Mo}_{2} \mathrm{~S}_{2}$ cores of $\left[-\mathrm{S}\left\{\mathrm{Mo}_{2}\right\} \mathrm{SOBn}\right]^{+}$and $\left[\mathrm{BnS}\left\{\mathrm{Mo}_{2}\right\} \mathrm{SOEt}\right]^{+}$, one can see that they are very close to planarity with dihedral angles (S(1)-Mo(1)-Mo(2)-S(2)) of 176.75(3) and $175.85(8)^{\circ}$.

Generally all Mo-S bond lengths on the same plane with the $\mu$-S-ligand of the $\left[-\mathrm{S}\left\{\mathrm{Mo}_{2}\right\} \mathrm{SOBn}\right]^{+}$dimer are similar to the Mo-S bond lengths of $\left[\mathrm{BnS}\left\{\mathrm{Mo}_{2}\right\} \mathrm{SOEt}\right]^{+}$. Other comparable features include the $\mathrm{S}(1)-\mathrm{O}(7)$ bond lengths that are 1.6502(19) and 1.655(2) $\AA$, and and O-C (alkyl) bond lengths which were 1.431(4) and 1.466(8) $\AA$. The angles at $\mathrm{O}$ were $113.7(5)$ and $115.79(18)^{\circ}$. The sulfur is pyramidal in both cases, with the sum of the angles at $\mathrm{S}(1)$ at $287.2(2)^{\circ}$ and $287.4(3)^{\circ}$. The $\mathrm{S}(2)-\mathrm{S}(7)$ disulfide bridge is 2.0884(9) $\AA$ and that of $\mathrm{S}\left\{\mathrm{Mo}_{2}\right\} \mathrm{SS}\left\{\mathrm{Mo}_{2}\right\} \mathrm{S}$ is 2.075(2) $\AA$, which means that the cation attached to the [S $\left.\left\{\mathrm{MO}_{2}\right\} \mathrm{S}-\right]$ did not seem to have much effect on the core structure of the molecules. Another interesting feature is that both bonds were within the range for organic sulfides (2.03-2.08 $\AA$ ), closer to aryl disulfides and longer than alkyl disulfides. ${ }^{35,36}$ The results also seem to agree with the order of relative strength of these bonds based on previous study of the photochemistry of these compounds. ${ }^{28,37}$ 

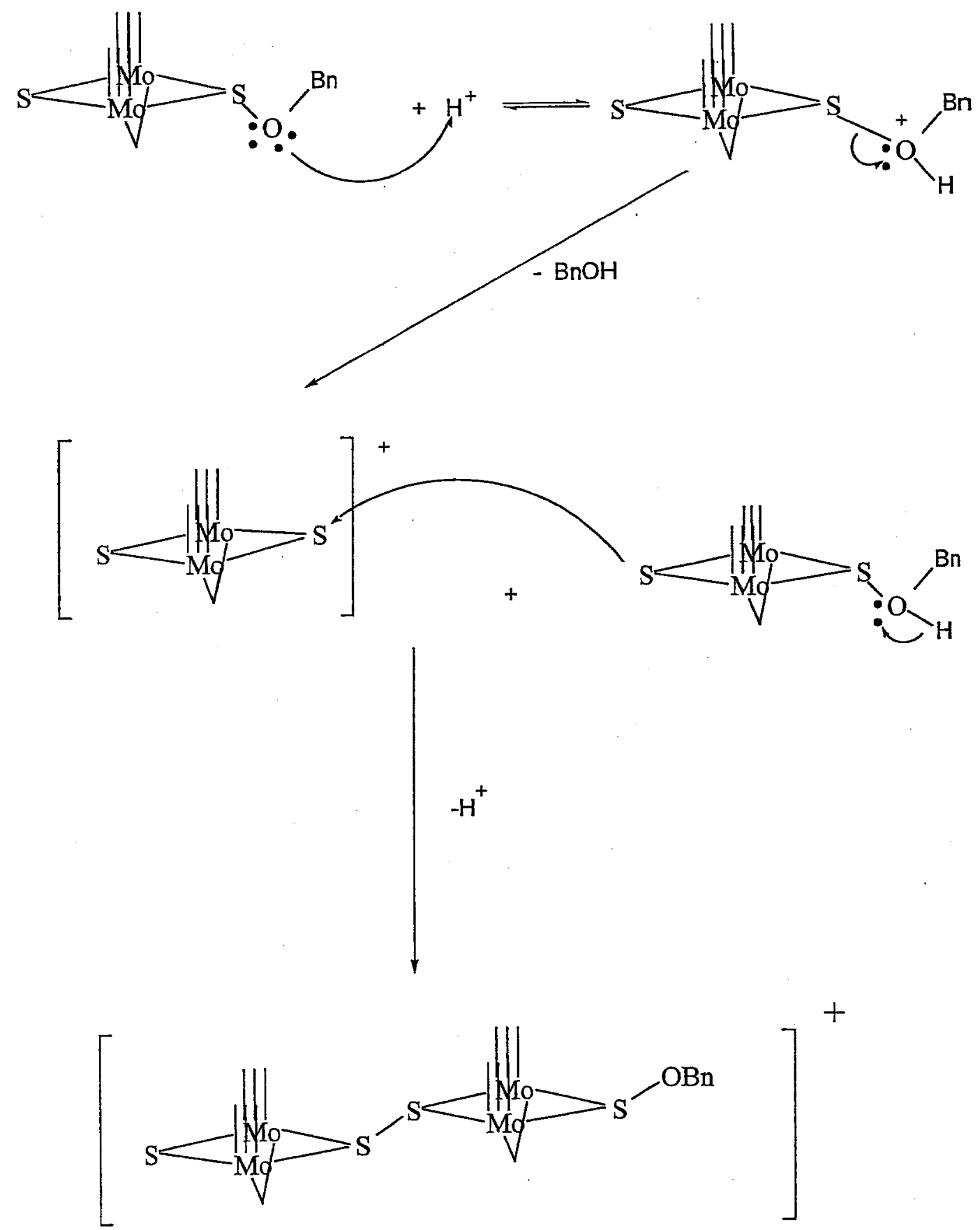

Scheme 3.2: Proposed stepwise mechanism of $\left[\mathrm{S}\left\{\mathrm{Mo}_{2}\right\} \mathrm{SS}\left\{\mathrm{Mo}_{2}\right\} \mathrm{SOBn}\right]^{+}$formation 


\section{Discussion}

The cation $\left[\mathrm{BnS}\left\{\mathrm{Mo}_{2}\right\} \mathrm{SOR}\right]^{+}$is reactive and can undergo de-benzylation to give $\mathrm{S}\left\{\mathrm{Mo}_{2}\right\} \mathrm{SOBn}$ or the cation can undergo de-ethylation to produce $\mathrm{BnS}\left\{\mathrm{Mo}_{2}(\mathrm{P}=0)\right\} \mathrm{SOBn}$ which is the decomposition product. The reaction is very time sensitive due to the two competing reactions. During a series of timed experiments it was determined that the maximum amount of $\mathrm{S}\left\{\mathrm{Mo}_{2}\right\} \mathrm{SOBn}$ relative to $\mathrm{BnS}\left\{\mathrm{Mo}_{2}(\mathrm{P}=\mathrm{O})\right\} \mathrm{SOBn}$ was produced at approximately three hours of reaction of $\mathrm{BnS}\left\{\mathrm{Mo}_{2}\right\} \mathrm{SO}$ using four-fold $\mathrm{BnBr}$. Additional time resulted in more $\mathrm{BnS}\left\{\mathrm{Mo}_{2}(\mathrm{P}=\mathrm{O})\right\} \mathrm{SOBn}$ A major improvement over previous preparations of the methyl and ethyl derivatives $\mathrm{S}\left\{\mathrm{Mo}_{2}\right\} \mathrm{SOMe}$ and $\mathrm{S}\left\{\mathrm{Mo}_{2}\right\}$ SOEt was that those were synthesized from the cations, $\left[\mathrm{BnS}\left\{\mathrm{Mo}_{2}\right\} \mathrm{SOR}\right]^{+}$, while in the present work, it proved possible to synthesize the benzyl derivate $\mathrm{S}\left\{\mathrm{Mo}_{2}\right\} \mathrm{SOBn}$ directly from $\mathrm{BnS}\left\{\mathrm{Mo}_{2}\right\} \mathrm{SO}$, by reacting with excess benzyl bromide. Everything was done in one pot which avoided the isolation of the cation, $\left[\mathrm{BnS}\left\{\mathrm{Mo}_{2}\right\} \mathrm{SOBn}\right]^{+}$. The ability to isolate $\mathrm{S}\left\{\mathrm{Mo}_{2}\right\} \mathrm{SOBn}$ cleanly through this route was due to the facile kinetics of benzyl displacement.

The compound, $\mathrm{S}\left\{\mathrm{Mo}_{2}\right\} \mathrm{SOBn}$, is structurally close to $\mathrm{S}\left\{\mathrm{Mo}_{2}\right\} \mathrm{SOCH}_{3}$ and $\mathrm{S}\left\{\mathrm{Mo}_{2}\right\} \mathrm{SNH}_{2}$. Since the bridging sulfur is bonded to highly electronegative atoms, this will create a partial positive charge on the sulfur and partial negative charge on the nitrogen and oxygen atom. ${ }^{27}$ Just like $\mathrm{S}\left\{\mathrm{Mo}_{2}\right\} \mathrm{SOCH}_{3}, \mathrm{~S}\left\{\mathrm{Mo}_{2}\right\} \mathrm{SOBn}$ showed the usual ligand sets but no definitive S-O vibration when characterized by IR spectroscopy.

Chi Minh Tuong treated $\mathrm{S}\left\{\mathrm{Mo}_{2}\right\} \mathrm{SOCH}_{3}$ with $\mathrm{HBF}_{4}$, though he did not obtain crystal data to support the structure $\left[\mathrm{S}\left\{\mathrm{Mo}_{2}\right\} \mathrm{SS}\left\{\mathrm{Mo}_{2}\right\} \mathrm{SOCH}_{3}\right]^{+}$(eq 3.0). The ${ }^{1} \mathrm{H}$ NMR spectrum of the product supported the idea that a bis-dimer of $\mathrm{S}\left\{\mathrm{Mo}_{2}\right\} \mathrm{SOCH}_{3}$ had been

formed. ${ }^{25}$ June Lee treated the amide nitrogen of $\mathrm{S}\left\{\mathrm{MO}_{2}\right\} \mathrm{SNH}_{2}$ with $\mathrm{HBF}_{4} \cdot \mathrm{OEt}_{2}$ and a 
compound that was formed was identified as bis-dimer $\left[\mathrm{S}\left\{\mathrm{Mo}_{2}\right\} \mathrm{SS}\left\{\mathrm{Mo}_{2}\right\} \mathrm{SNH}_{2}\right]^{+}$as shown by eq $3.7 .^{33}$ This shows that all three of these related compounds were capable of forming bis-dimer because of the electronegativity of the substituent in $\mu-\mathrm{S}-\mathrm{Z}$.
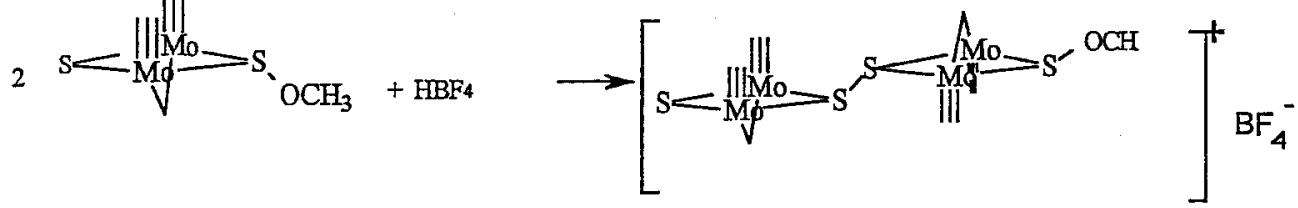

$+\quad \mathrm{CH}_{3} \mathrm{OH}$

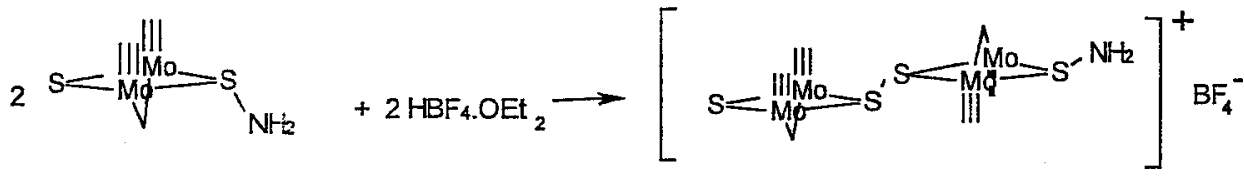

$+\mathrm{NH}_{4} \mathrm{BF}_{4}+2 \mathrm{OEt}_{2}$

Previous photolysis studies of $\mathrm{S}\left\{\mathrm{Mo}_{2}\right\} \mathrm{SSR}$ compounds showed that the compounds were prone to photohomolysis forming $\mathrm{SR}^{\circ}$ and $\mathrm{Mo}_{2} \mathrm{~S}^{\circ}$ radicals. ${ }^{24,28,29}$ $2 \mathrm{~S}\left\{\mathrm{Mo}_{2}\right\} \mathrm{SSR} \longrightarrow \mathrm{hv} \longrightarrow \mathrm{S}\left\{\mathrm{Mo}_{2}\right\} \mathrm{SS}\left\{\mathrm{Mo}_{2}\right\} \mathrm{S}+\mathrm{RSSR}$ The overall step of this reaction is the homolysis of the S-S bond by hv as shown in eq 3.8. The termination step involves the recombination step that produces the disulfides shown by eq 3.9 and 3.10 .

2 RS ·

RSSR

$2 \mathrm{~S}\left\{\mathrm{Mo}_{2}\right\} \mathrm{S}$

$$
\mathrm{S}\left\{\mathrm{Mo}_{2}\right\} \mathrm{SS}\left\{\mathrm{Mo}_{2}\right\} \mathrm{S}
$$

The R group influences the rate at which the $\left\{\mathrm{Mo}_{2}\right\}$ SSR photolysed. Aryl precursors are more reactive than alkyl precursors and that increases the rate of photolysis with visible light. This could possibly be due to the stabilization of the resonance that aryl thiyl radicals can have. ${ }^{25}$ The $\left\{\mathrm{Mo}_{2}\right\}$ SSR compounds are 
photosensitive, which is why the reaction had to be carried in subdued indirect light.

$\mathrm{Me}_{2} \mathrm{CO}$ was used as solvent for the formation of $\left[\mathrm{S}\left\{\mathrm{Mo}_{2}\right\} \mathrm{SS}\left\{\mathrm{Mo}_{2}\right\} \mathrm{SOBn}\right]^{+}$from $\mathrm{S}\left\{\mathrm{Mo}_{2}\right\} \mathrm{SOBn}$. The proposed reaction is shown in Scheme 3.2. The site of protonation of the $\mathrm{S}\left\{\mathrm{Mo}_{2}\right\} \mathrm{SOBn}$ is the oxygen due to its basicity. The sulfur could be another possible site, however it is less electronegative than the oxygen. The presence of the two lone pairs would reinforce the basicity of the oxygen. It is suggested that the $\mathrm{S}\left\{\mathrm{MO}_{2}\right\} \mathrm{SOBnH}^{+}$ dissociates to generate $\mathrm{S}\left\{\mathrm{Mo}_{2}\right\} \mathrm{S}^{+}$and $\mathrm{BnOH}$. The production of $\mathrm{S}\left\{\mathrm{Mo}_{2}\right\} \mathrm{S}^{+}$electrophile will lead to its attack by $\mathrm{S}\left\{\mathrm{Mo}_{2}\right\} \mathrm{SOBn}$ nucleophile leading to the formation of dimer of dimers. 


\section{CONCLUSION}

Whilst it proved possible to synthesize different $\mathrm{BnS}\left\{\mathrm{M}_{2}\right\}$ SO derivatives, there is no clear explanation to the trend in their decompositions. The reason could be due to a combination of factors which include steric bulkiness, $\mathrm{Kb}$ values and their arrangements in crystalline phase. Without the crystalline phase of each of these compounds it is difficult to give a clear explanation to these results.

The synthesis of methyl and ethyl derivatives which are $\mathrm{S}\left\{\mathrm{Mo}_{2}\right\} \mathrm{SOMe}$ and $\mathrm{S}\left\{\mathrm{Mo}_{2}\right\}$ SOEt were synthesized through a two pot synthesis by prior students, how ever, in this work the synthesis of the benzyl derivative, $\mathrm{S}\left\{\mathrm{Mo}_{2}\right\} \mathrm{SOBn}$, was done directly from $\mathrm{BnS}\left\{\mathrm{Mo}_{2}\right\} \mathrm{SO}$ with excess benzyl bromide in a one pot synthesis.

The protonation of $\mathrm{S}\left\{\mathrm{Mo}_{2}\right\} \mathrm{SOBn}$ by a strong inorganic acid like $\mathrm{HBF}_{4}$ occurred at the S-O bond's oxygen. It produced the bis-dimer, $\left[\mathrm{S}\left\{\mathrm{Mo}_{2}\right\} \mathrm{SS}_{2}\left\{\mathrm{Mo}_{2}\right\} \mathrm{SOBn}\right] \mathrm{BF}{ }_{4}$. This reaction was conducted in subdued, indirect light. The neutral portion of this bis-dimer had bond angles and bonding distances that were similar to those of $\mathrm{S}\left\{\mathrm{Mo}_{2}\right\} \mathrm{SS}\left\{\mathrm{Mo}_{2}\right\} \mathrm{S}$ and the cation portion of the bis-dimer also gave very comparable results of bonding distances and bonding angles when compared to $\left[\mathrm{BnS}\left\{\mathrm{Mo}_{2}\right\} \mathrm{SOEt}\right]^{+}$that had been synthesized by prior researchers. 


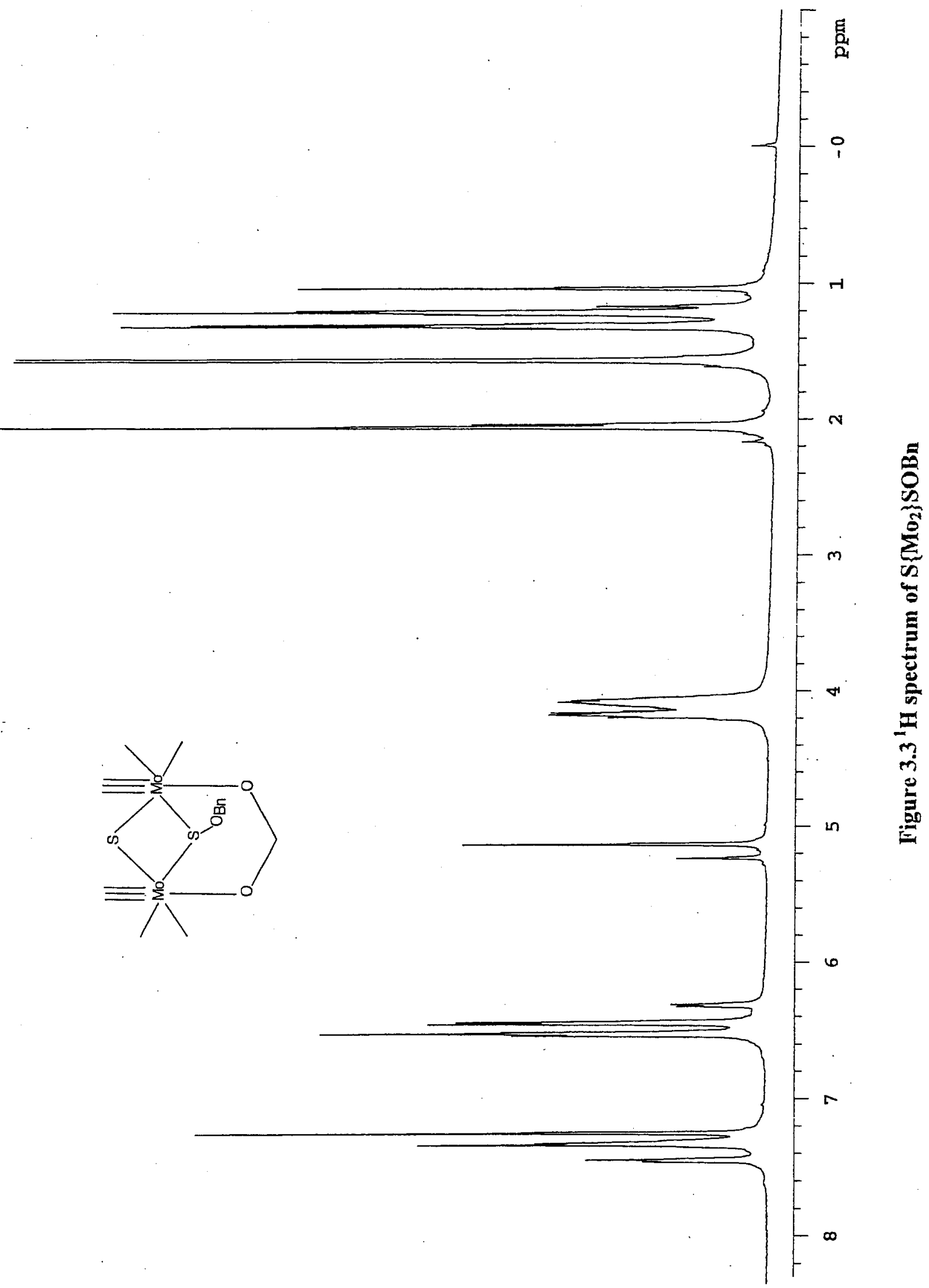




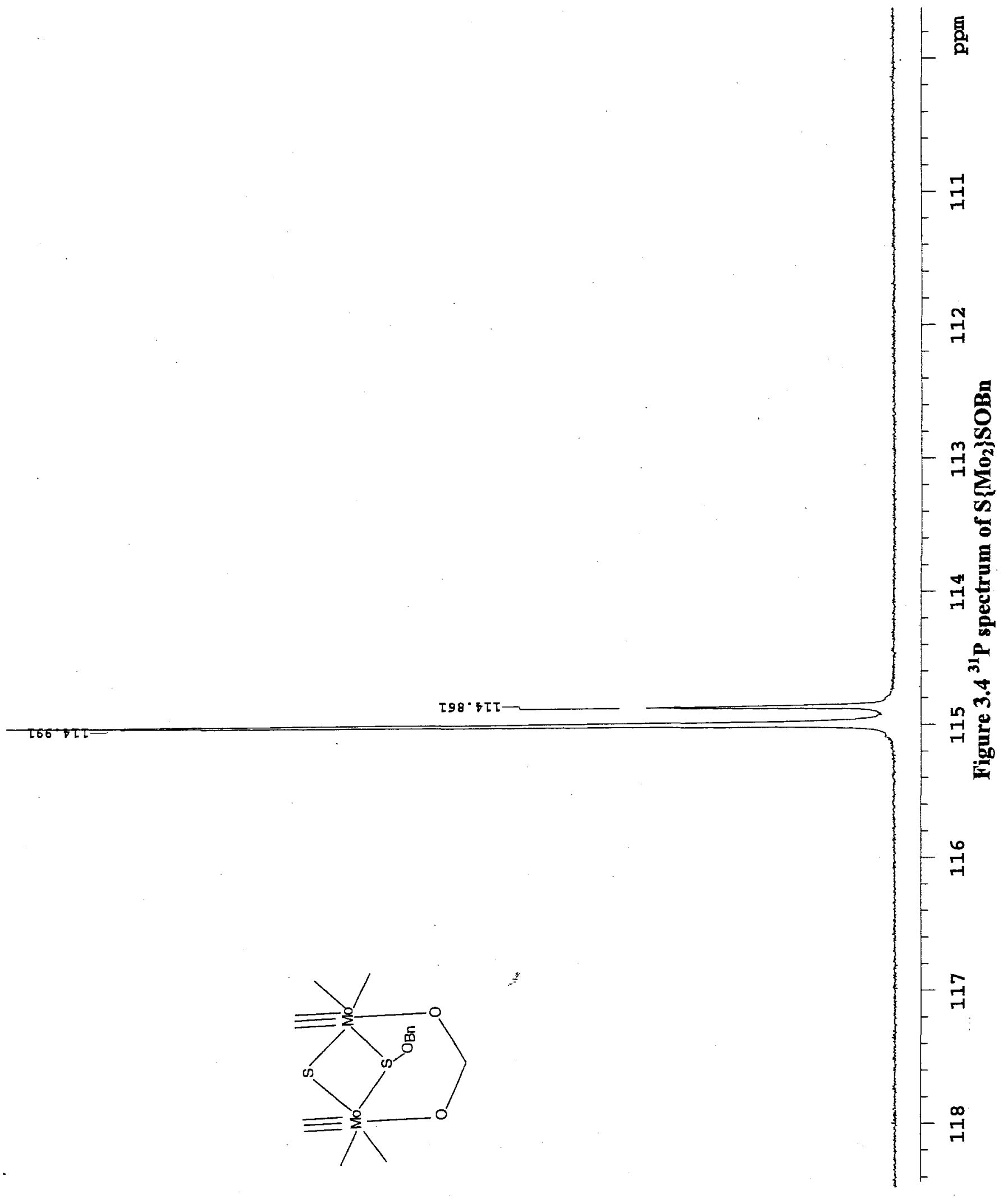




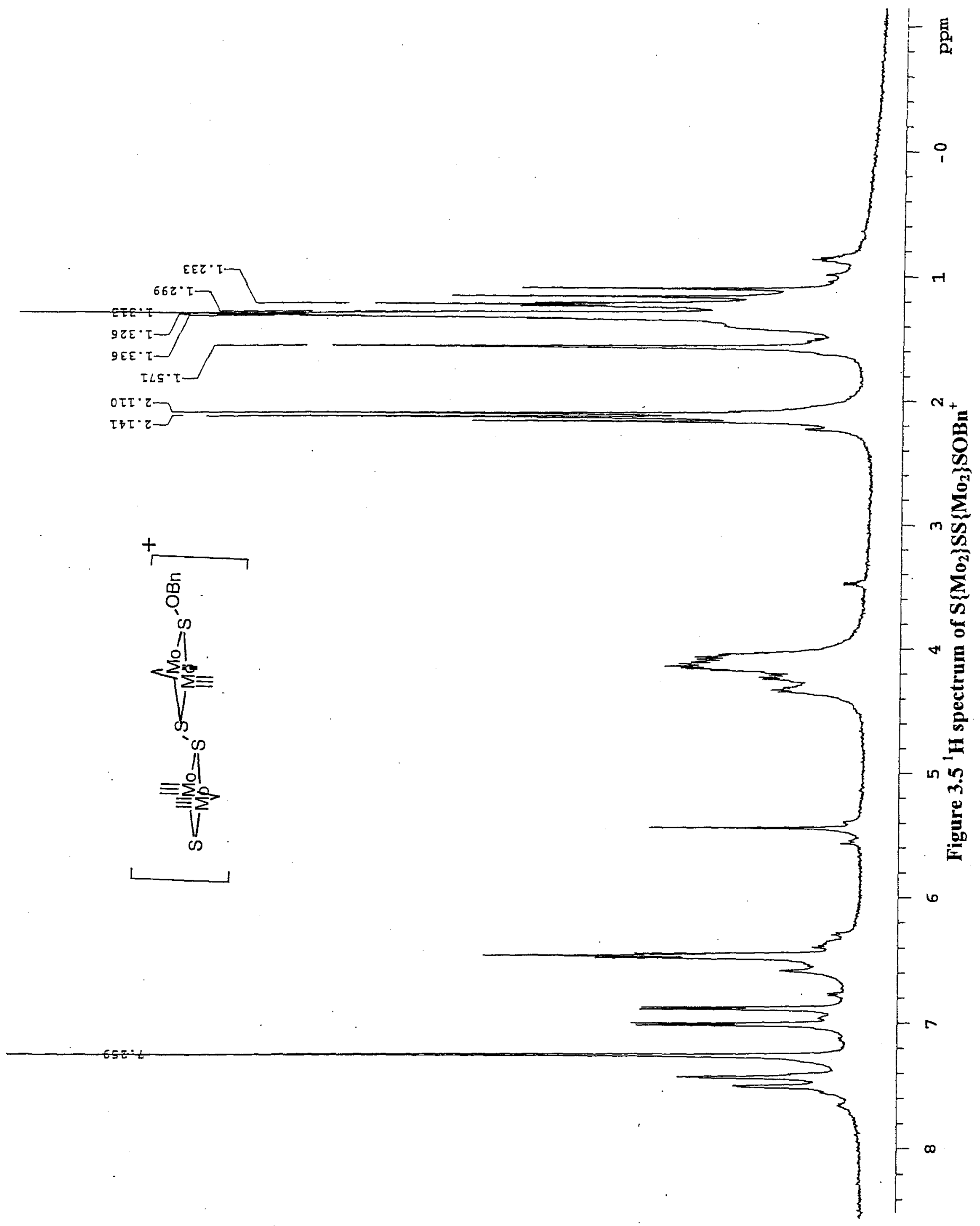




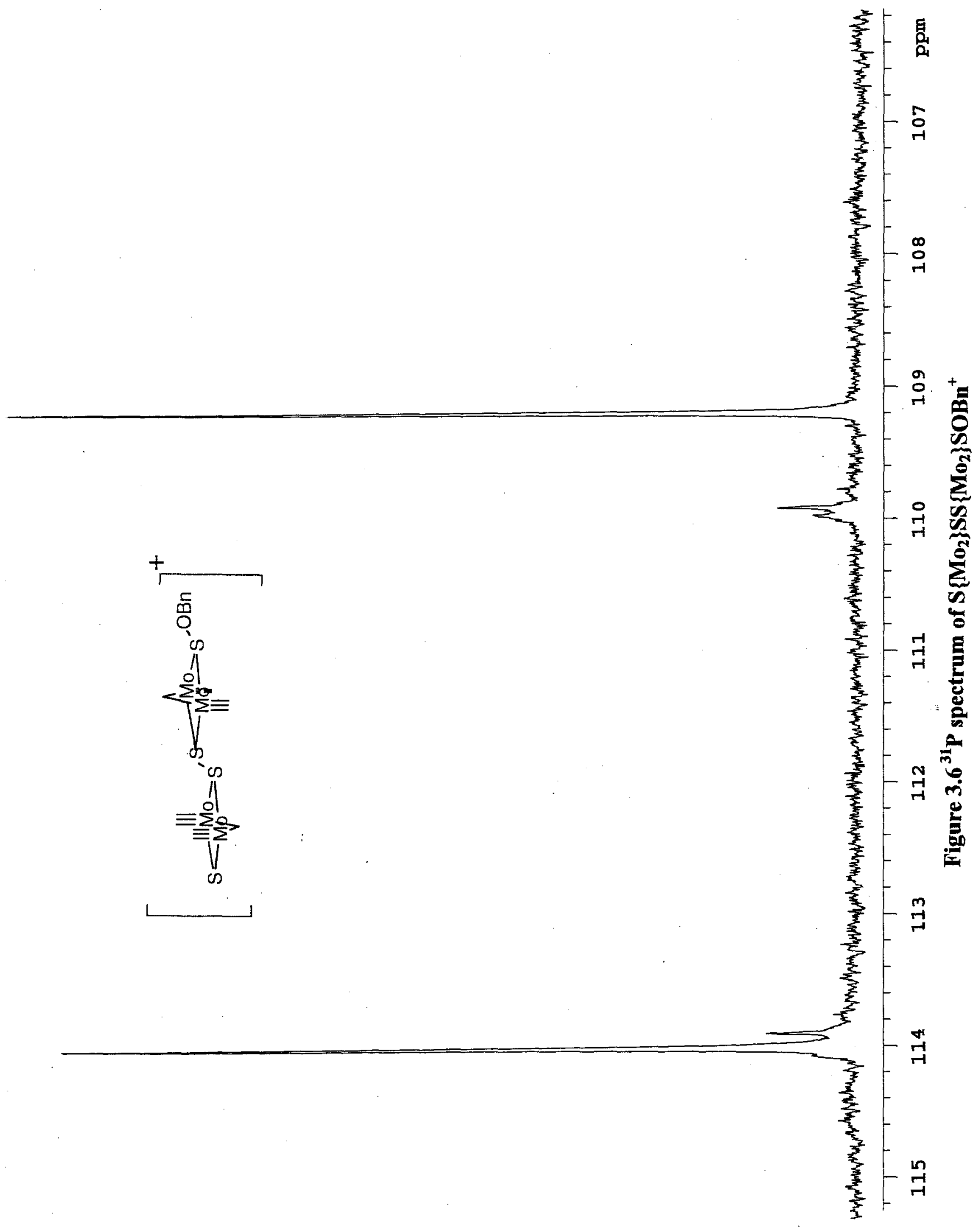




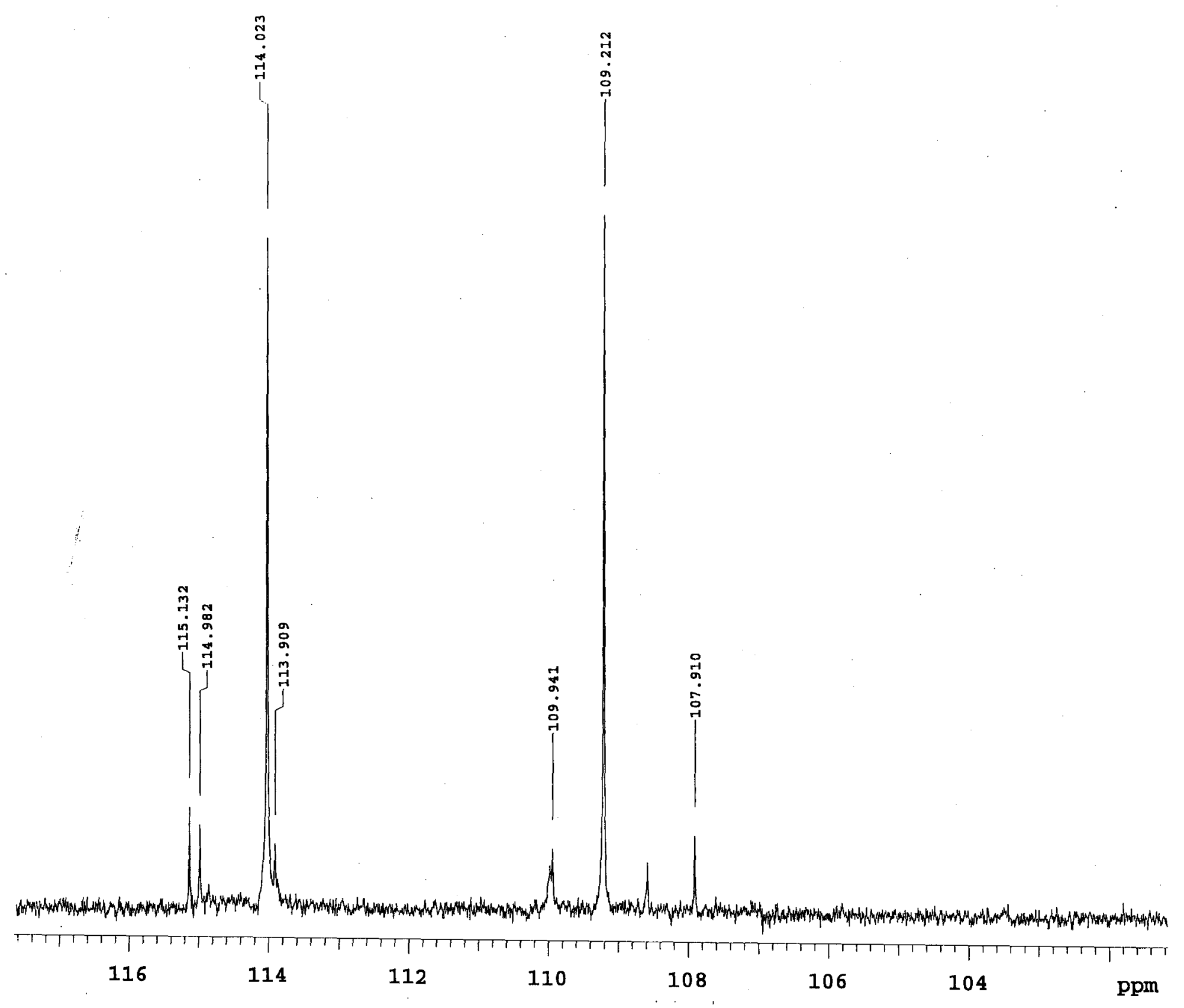

Figure 3.7. ${ }^{31} \mathrm{P}$ spectrum of photolysed $\mathrm{S}\left\{\mathrm{Mo}_{2}\right\} \mathrm{SS}\left\{\mathrm{Mo}_{2}\right\} \mathrm{SOBn}^{+}$ 


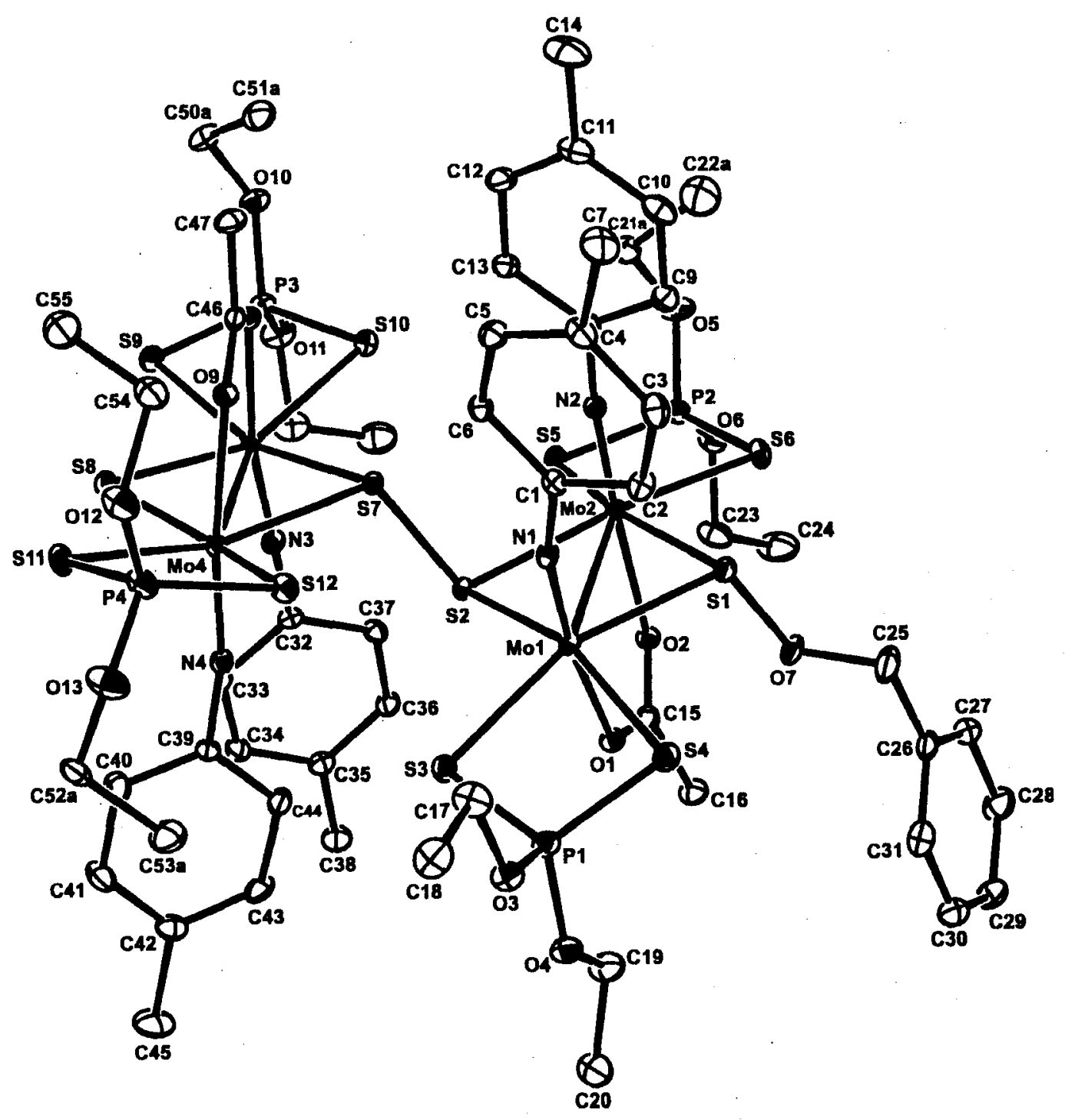

Figure 3.8. ORTEP view $\mathrm{S}\left\{\mathrm{Mo}_{2}\right\} \mathrm{SS}\left\{\mathrm{Mo}_{2}\right\} \mathrm{SOBn}^{+}$ 


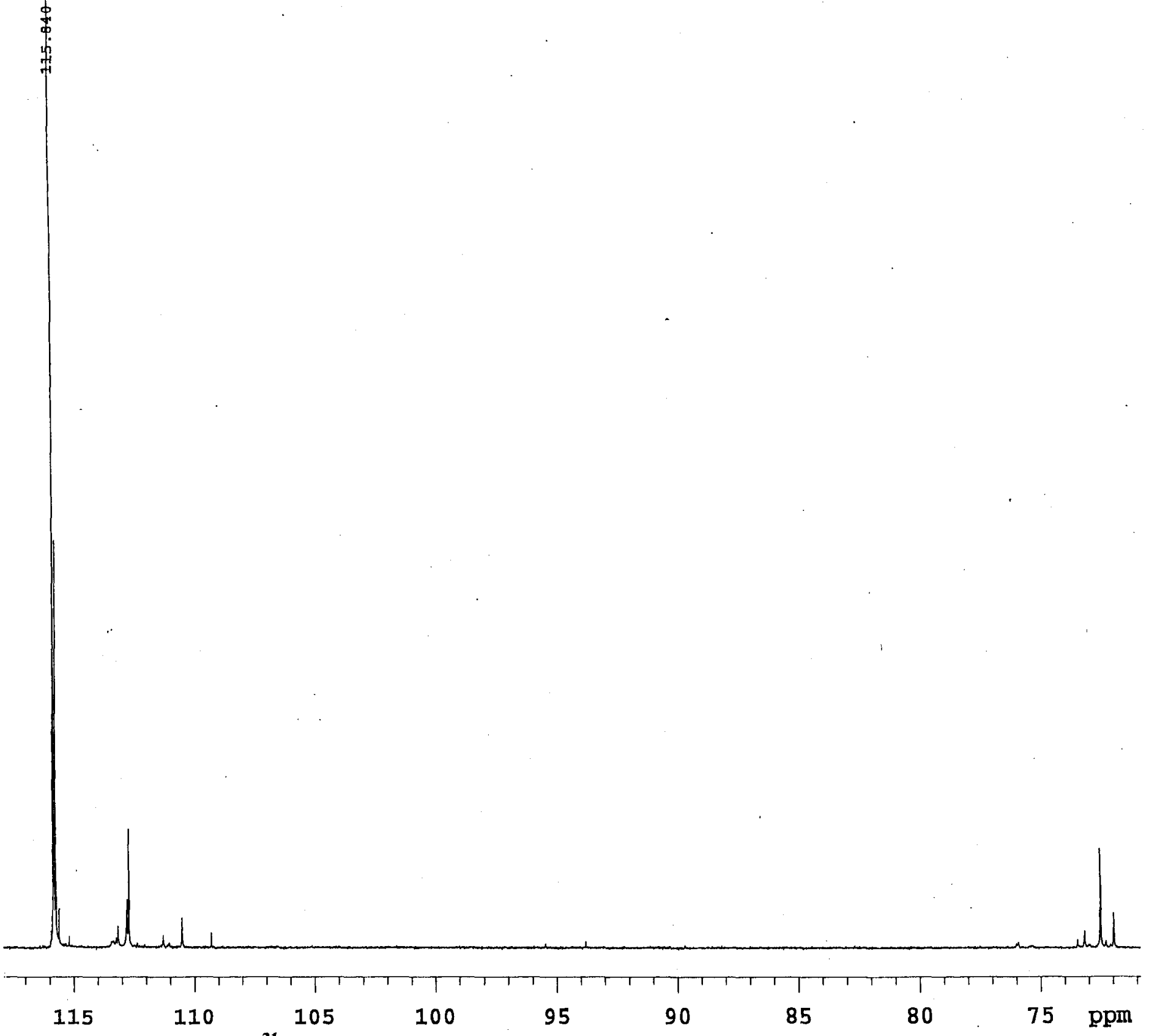

Figure $3.9^{31} \mathrm{P}$ spectrum taken during the reaction of $\mathrm{BnS}\left\{\mathrm{Mo}_{2}\right\} \mathrm{SO}$ and $\mathrm{BnBr}$ 


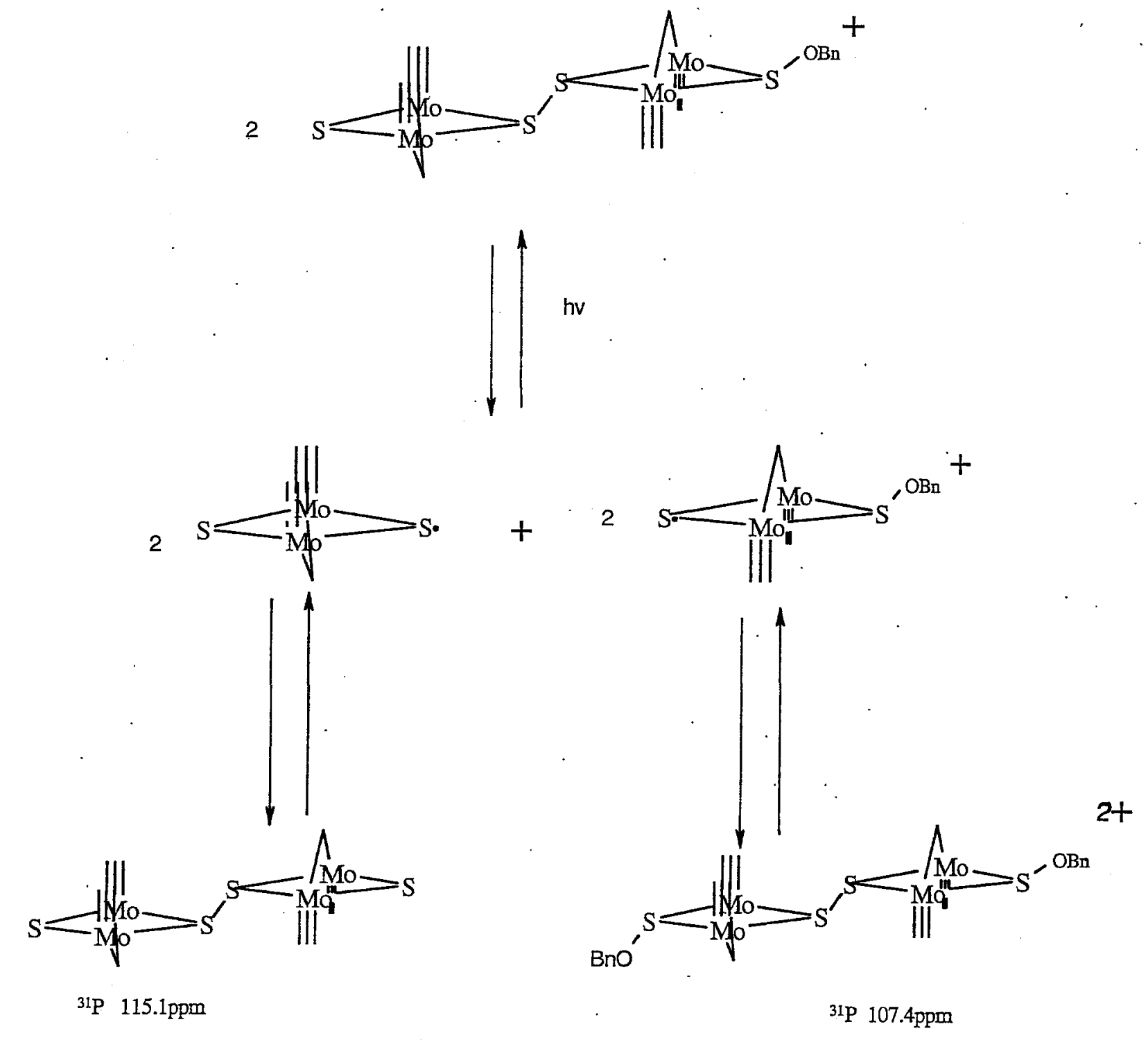

Scheme 3.3: Proposed mechanism of $\left[\mathrm{S}\left\{\mathrm{MO}_{2}\right\} \mathrm{SS}\left\{\mathrm{Mo}_{2}\right\} \mathrm{SOBn}\right]^{+}$radical reactions 

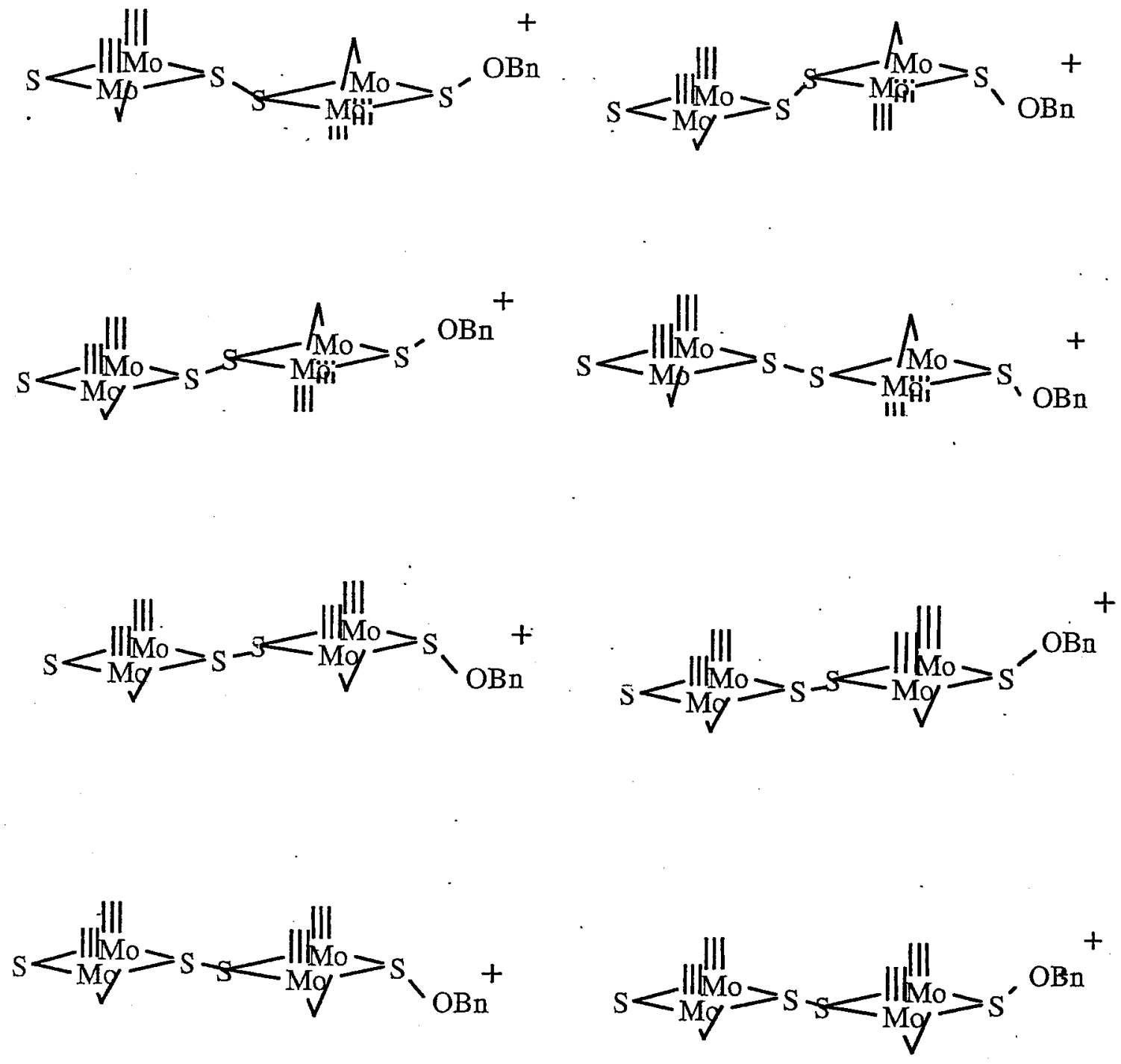

Figure 3.10. Possible isomers of the cation, $\left[\mathrm{Mo}_{2} \mathrm{SSMO}_{2} \mathrm{SOBn}\right]^{+}$ 
Table 3.1: Crystallographic data for $\left[\mathrm{S}\left\{\mathrm{Mo}_{2}\right\} \mathrm{SS}\left\{\mathrm{Mo}_{2}\right\} \mathrm{SOBn}\right] \mathrm{BF}$

$\begin{array}{ll}\text { Formula } & \mathrm{C}_{55} \mathrm{H}_{81} \mathrm{Mo}_{4} \mathrm{~N}_{4} \mathrm{O}_{13} \mathrm{P}_{4} \mathrm{~S}_{12} \mathrm{~B} \mathrm{~F}_{4} \mathrm{C}_{6} \mathrm{H}_{6} \\ \text { FW } & 2063.52 \\ \text { Space group } & \mathrm{P} 2{ }_{1} / \mathrm{n} \\ \text { a } & 13.48583(19) \AA \\ \text { b } & 31.4779(4) \AA \\ \text { c } & 19.7888(3) \AA \\ \alpha & 90^{\circ} . \\ \beta & 93.4618(13)^{\circ} . \\ \gamma & 90^{\circ} \\ \text { Volume } & 8385.1(2) \AA^{3} \\ \text { Density (calculated) } & 1.635{\mathrm{Mg} / \mathrm{m}^{3}}^{3} \\ \text { Absorption coefficient } & 1.025 \mathrm{~mm}^{-1} \\ \text { Reflections collected } & 68625 \\ \text { Independent reflections } & 19188[\mathrm{R}(\mathrm{int})=0.0238]\end{array}$


Table 3.2. Selected Positional Parameters for $\left[\mathrm{S}\left\{\mathrm{Mo}_{2}\right\} \mathrm{SS}\left\{\mathrm{Mo}_{2}\right\} \mathrm{SOBn}\right]^{+}$

\begin{tabular}{|c|c|c|c|c|}
\hline Atom & $\mathrm{X}$ & $\mathrm{Y}$ & $Z$ & $\mathrm{U}(\mathrm{eq})$ \\
\hline $\mathrm{Mo}(1)$ & $9056(1)$ & $1543(1)$ & $1376(1)$ & $17(1)$ \\
\hline $\mathrm{Mo}(2)$ & $7171(1)$ & $1144(1)$ & $1596(1)$ & $17(1)$ \\
\hline $\mathrm{Mo}(3)$ & $8140(1)$ & $1277(1)$ & $4244(1)$ & $18(1)$ \\
\hline Mo(4) & $9731(1)$ & $1814(1)$ & $3897(1)$ & $18(1)$ \\
\hline $\mathrm{S}(1)$ & $7631(1)$ & $1495(1)$ & $570(1)$ & $20(1)$ \\
\hline$S(2)$ & $8643(1)$ & $1158(1)$ & $2404(1)$ & $16(1)$ \\
\hline $\mathrm{S}(3)$ & $10813(1)$ & $1538(1)$ & $1852(1)$ & $24(1)$ \\
\hline$S(4)$ & $9957(1)$ & $1766(1)$ & $358(1)$ & $27(1)$ \\
\hline$S(5)$ & $6459(1)$ & $615(1)$ & $2370(1)$ & $27(1)$ \\
\hline$S(6)$ & $5729(1)$ & $872(1)$ & $868(1)$ & $26(1)$ \\
\hline$S(7)$ & $8304(1)$ & $1612(1)$ & $3124(1)$ & $17(1)$ \\
\hline $\mathrm{S}(8)$ & $9388(1)$ & $1567(1)$ & $4976(1)$ & $24(1)$ \\
\hline$S(9)$ & $7474(1)$ & $1068(1)$ & $5355(1)$ & $27(1)$ \\
\hline$S(10)$ & $6368(1)$ & $1054(1)$ & $3887(1)$ & $26(1)$ \\
\hline$S(11)$ & $10846(1)$ & $2286(1)$ & $4616(1)$ & $31(1)$ \\
\hline$S(12)$ & $10275(1)$ & $2358(1)$ & $3035(1)$ & $25(1)$ \\
\hline$P(1)$ & $11224(1)$ & $1690(1)$ & $927(1)$ & $24(1)$ \\
\hline$P(2)$ & $5327(1)$ & $550(1)$ & $1678(1)$ & $24(1)$ \\
\hline$P(3)$ & $6239(1)$ & $874(1)$ & $4843(1)$ & $26(1)$ \\
\hline $\mathrm{P}(4)$ & $11006(1)$ & $2654(1)$ & $3806(1)$ & $30(1)$ \\
\hline$O(1)$ & $9382(1)$ & $910(1)$ & $1048(1)$ & $21(1)$ \\
\hline
\end{tabular}


Table 3.3. Selected Bond Angles (deg) for $\left[\mathrm{S}\left\{\mathrm{Mo}_{2}\right\} \mathrm{SS}\left\{\mathrm{Mo}_{2}\right\} \mathrm{SOBn}\right]^{+}$and $\left[\mathrm{BnS}\left\{\mathrm{Mo}_{2}\right\} \mathrm{SOEt}\right]^{+}$

$\left[\mathrm{BnS}\left\{\mathrm{Mo}_{2}\right\} \mathrm{SOEt}\right]^{+} \quad\left[\mathrm{S}\left\{\mathrm{Mo}_{2}\right\} \mathrm{SS}\left\{\mathrm{Mo}_{2}\right\} \mathrm{SOBn}\right]^{+}$

$\begin{array}{lcc}\mathrm{S}(1)-\mathrm{Mo}(2)-\mathrm{S}(2) & 107.34(17) & 107.9(65) \\ \mathrm{N}(1)-\mathrm{Mo}(1)-\mathrm{O}(1) & 172.61(9) & 175.1(2) \\ \mathrm{S}(5)-\mathrm{Mo}(2)-\mathrm{S}(6) & 79.47(7) & 79.09(2) \\ \mathrm{O}(1)-\mathrm{Mo}(1)-\mathrm{N}(1) & 172.61(9) & 175.1(2) \\ \mathrm{Mo}(1)-\mathrm{S}(1)-\mathrm{Mo}(2) & 72.33(5) & 73.14(3) \\ \mathrm{Mo}(1)-\mathrm{S}(1)-\mathrm{O}(7) & 106.87(18) & 107.28(8) \\ \mathrm{S}(1)-\mathrm{Mo}(1)-\mathrm{S}(2) & 107.65(2) & 107.60(6) \\ \mathrm{Mo}(2)-\mathrm{S}(1)-\mathrm{O}(7) & 108.18(19) & 106.00(7) \\ \mathrm{Mo}(1)-\mathrm{S}(2)-\mathrm{Mo}(2) & 72.30(5) & 71.803(19) \\ \mathrm{S}(1)-\mathrm{Mo}(1)-\mathrm{Mo}(2)-\mathrm{S}(2) & 176.85(8) & 176.75(3) \\ \mathrm{Mo}(2)-\mathrm{S}(1)-\mathrm{O}(7)-\mathrm{C}(25) & 175.8(4) & 152.3(2) \\ \mathrm{Mo}(1)-\mathrm{S}(1)-\mathrm{O}(7)-\mathrm{C}(25) & 107.8(4) & 130.8(2) \\ \mathrm{C}(25)-\mathrm{O}(7)-\mathrm{S}(1) & 113.7(5) & 115.79(18) \\ \text { Sum of angles at S(1) } & 287.4(3) & 287.2(2)\end{array}$


Table 3.4. Selected Bond Angles (deg) for $\left[\mathrm{S}\left\{\mathrm{MO}_{2}\right\} \mathrm{SS}\left\{\mathrm{Mo}_{2}\right\} \mathrm{SOBn}\right]^{+}$and $\mathrm{S}\left\{\mathrm{Mo}_{2}\right\} \mathrm{SS}\left\{\mathrm{Mo}_{2}\right\} \mathrm{S}$

\begin{tabular}{lcc}
\hline & {$\left[\mathrm{S}\left\{\mathrm{Mo}_{2}\right\} \mathrm{SS}\left\{\mathrm{Mo}_{2}\right\} \mathrm{SOBn}\right]^{+}$} & $\mathrm{S}\left\{\mathrm{Mo}_{2}\right\} \mathrm{SS}\left\{\mathrm{Mo}_{2}\right\} \mathrm{S}$ \\
\hline $\mathrm{S}(8)-\mathrm{Mo}(3)-\mathrm{S}(7)$ & $106.76(2)$ & $106.69(4)$ \\
$\mathrm{Mo}(3)-\mathrm{S}(8)-\mathrm{Mo}(4)$ & $74.89(2)$ & $75.16(4)$ \\
$\mathrm{Mo}(4)-\mathrm{S}(7)-\mathrm{Mo}(3)$ & $70.303(19)$ & $70.74(4)$ \\
$\mathrm{S}(8)-\mathrm{Mo}(3)-\mathrm{S}(9)$ & $80.90(3)$ & $80.70(4)$ \\
$\mathrm{S}(7)-\mathrm{Mo}(3)-\mathrm{S}(9)$ & $90.15(2)$ & $90.58(4)$ \\
$\mathrm{S}(9)-\mathrm{Mo}(3)-\mathrm{S}(10)$ & $77.98(2)$ & $77.76(5)$ \\
$\mathrm{N}(4)-\mathrm{Mo}(4)-\mathrm{O}(9)$ & $173.31(9)$ & $172.1(2)$ \\
$\mathrm{N}(4)-\mathrm{Mo}(4)-\mathrm{Mo}(3)$ & $99.35(7)$ & $99.4(1)$ \\
$\mathrm{S}(8)-\mathrm{Mo}(4)-\mathrm{S}(7)$ & $106.87(2)$ & $106.29(3)$ \\
$\mathrm{O}(8)-\mathrm{Mo}(3)-\mathrm{Mo}(4)$ & $82.83(5)$ & $82.09(6)$ \\
$\mathrm{N}(3)-\mathrm{Mo}(3)-\mathrm{O}(8)$ & $170.43(9)$ & $172.0 .(9)$ \\
$\mathrm{Mo}(3)-\mathrm{S}(8)-\mathrm{Mo}(4)$ & $74.89(2)$ & $75.16(4)$ \\
$\mathrm{S}(7)-\mathrm{Mo}(3)-\mathrm{S}(10)$ & $90.15(2)$ & $88.72(4)$
\end{tabular}


Table 3.5. Selected Bond length $(\AA)$ for $\left[\mathrm{S}\left\{\mathrm{Mo}_{2}\right\} \mathrm{SS}\left\{\mathrm{MO}_{2}\right\} \mathrm{SOBn}\right]^{+}$and $\left.\mathrm{BnS}\left\{\mathrm{Mo}_{2}\right\} \mathrm{SOEt}\right]^{+}$

\begin{tabular}{|c|c|c|}
\hline & {$\left[\mathrm{S}\left\{\mathrm{Mo}_{2}\right\} \mathrm{SS}\left\{\mathrm{Mo}_{2}\right\} \mathrm{SOBn}\right]^{+}$} & {$\left[\mathrm{BnS}\left\{\mathrm{Mo}_{2}\right\} \mathrm{SOEt}\right]^{+}$} \\
\hline $\operatorname{Mo}(1)-\operatorname{Mo}(2)$ & $2.8920(3)$ & $2.8807(5)$ \\
\hline $\mathrm{Mo}(1)-\mathrm{S}(1)$ & $2.4276(7)$ & $2.4378(17)$ \\
\hline $\mathrm{Mo}(1)-\mathrm{S}(2)$ & $2.4593(7)$ & $2.4454(18)$ \\
\hline $\mathrm{Mo}(2)-\mathrm{S}(1)$ & $2.4436(19)$ & $2.4260(7)$ \\
\hline $\mathrm{Mo}(2)-\mathrm{S}(2)$ & $2.4724(7)$ & $2.4382(17)$ \\
\hline $\mathrm{Mo}(1)-\mathrm{S}(4)$ & $2.5152(8)$ & $2.5144(19)$ \\
\hline $\mathrm{Mo}(2)-\mathrm{S}(5)$ & $2.4922(7)$ & $2.4969(19)$ \\
\hline $\mathrm{Mo}(2)-\mathrm{O}(2)$ & $2.1459(17)$ & $2.169(5)$ \\
\hline $\mathrm{Mo}(2)-\mathrm{S}(6)$ & $2.5007(7)$ & $2.495(2)$ \\
\hline $\operatorname{Mo}(1)-\mathrm{N}(1)$ & $1.735(2)$ & $1.721(6)$ \\
\hline $\mathrm{Mo}(2)-\mathrm{N}(2)$ & $1.736(2)$ & $1.718(6)$ \\
\hline $\mathrm{Mo}(1)-\mathrm{O}(1)$ & $2.1499(17)$ & $2.156(4)$ \\
\hline $\mathrm{Mo}(2)-\mathrm{O}(2)$ & $2.1459(17)$ & $2.169(5)$ \\
\hline $\mathrm{S}(1)-\mathrm{O}(7)$ & $1.655(5)$ & $1.6502(19)$ \\
\hline $\mathrm{O}(7)-\mathrm{C}(25)$ & $1.431(4)$ & $1.466(8)$ \\
\hline$S(6)-P(2)$ & $1.9994(11)$ & $1.998(3)$ \\
\hline
\end{tabular}


Table 3.6. Selected Bond length $(\AA)$ for $\left[\mathrm{S}\left\{\mathrm{Mo}_{2}\right\} \mathrm{SS}\left\{\mathrm{Mo}_{2}\right\} \mathrm{SOBn}\right]^{+}$and $\mathrm{S}\left\{\mathrm{Mo}_{2}\right\} \mathrm{SS}\left\{\mathrm{Mo}_{2}\right\} \mathrm{S}$

$\left[\mathrm{S}\left\{\mathrm{Mo}_{2}\right\} \mathrm{SS}\left\{\mathrm{Mo}_{2}\right\} \mathrm{SOBn}\right]^{+} \quad \mathrm{S}\left\{\mathrm{Mo}_{2}\right\} \mathrm{SS}\left\{\mathrm{Mo}_{2}\right\} \mathrm{S}$

$\begin{array}{lll}\mathrm{Mo}(3)-\mathrm{N}(3) & 1.732(2) & 1.731(4) \\ \mathrm{Mo}(3)-\mathrm{O}(8) & 2.2256(17) & 2.222(3) \\ \mathrm{Mo}(3)-\mathrm{S}(8) & 2.3381(7) & 2.338(1) \\ \mathrm{Mo}(3)-\mathrm{S}(7) & 2.4770(7) & 2.459(1) \\ \mathrm{Mo}(3)-\mathrm{S}(9) & 2.5125(8) & 2.509(1) \\ \mathrm{Mo}(3)-\mathrm{Mo}(4) & 2.8469(3) & 2.8534(4) \\ \mathrm{Mo}(4)-\mathrm{N}(4) & 1.737(2) & 1.729(4) \\ \mathrm{S}(9)-\mathrm{P}(3) & 1.9929(11) & 1.995(2) \\ \mathrm{O}(1)-\mathrm{C}(15) & 1.270(3) & 1.255(5) \\ \mathrm{N}(1)-\mathrm{C}(1) & 1.384(6) & 1.391(3) \\ \mathrm{N}(2)-\mathrm{C}(8) & 1.389(3) & 1.387(5) \\ \mathrm{Mo}(4)-\mathrm{S}(8) & 2.3442(8) & 2.341(1) \\ \mathrm{N}(3)-\mathrm{C}(32) & 1.384(3) & 1.384(6) \\ \mathrm{S}(2)-\mathrm{S}(7) & 2.0884(9) & 2.075(2) \\ \mathrm{P}(3)-\mathrm{S}(10) & 1.9914(11) & 1.995(2) \\ \mathrm{S}(2)-\mathrm{S}(7) & 2.0884(9) & 2.075(2)\end{array}$




\section{REFERENCES}

(1) Stiefel, E. I.; Coucouvanis, D.; Newton, W. E.; ACS Symposium Series 653; American Chemical Society; Washington, DC 1993; Chapter 1.

(2) Stiefel, E. I., in Transition Metal Sulfur Chemistry:Biological and Industrial Significance; Stiefel, E.I., Matsumoto, K., Eds.; ACS Symposium Series 653; American Chemical Society: Washington, DC, 1996; Chapter 1.

(3) Sloan, C. P.; Krueger, J. H. Inorg. Chem. 2002, 14, 1481-1485.

(4) Bortels, H. Arch. Mikrobiol. 1956, 25, 225-231.

(5) Johnson, M. K.; Rees, D. C.; Adams, M. W. Chem. Rev. 1996, 96, $2817-$ 2839.

(6) Kletzin, A.; Adams, M. W. FEMS Microbiol. Rev. 1996, 18, 5-63.

(7) Stiefel, E. I. Met. Ions. Biol. Syst. 2002, 39, 1-17.

(8) Stiefel, E. I. Transition Metal Sulfur Chemistry and Its Relevance to Molybdenum and Tungsten Enzymes 1998, 70, 889-894.

(9) Braverman, S. In The Chemistry of Sulphenic Acids and Derivatives;

Patai, S., Ed.; John Wiley and Sons: Chichester, U.K., 1990; pp 311-359.

(10) Braverman, S. In The Chemistry of Sulphones and Sulphoxides; Patai, S.;

Rappoport, Z.; Stirling, C.J.M.; Eds.; John Wiley and Sons, Chichester, U.K. 1988, pp 717-757.

(11) Lydon, J.D.; Deutsch, E. Inorg. Chem. 1982, 21, 3180-3185.

(12) Cope, A. C.; Caress, E. A. J. Am. Chem. Soc. 1966, 88, 1711-1713.

(13) Kubas, G. J. Acc. Chem. Res. 1994, 27, 183-190. 
(14) Hoots, J. E.; Rauchfuss, T. B.; Wilson, S. R. J. Chem. Soc., Chem. Commun. 1983, 1226-1228.

(15) Wang, R.; Mashuta, M. S.; Richardson, J. F.; Noble, M. E. Inorg. Chem. $1996,35,3022-3030$.

(16) Bottcher, H. C.; Graf, M.; Merzweiler, K.; Wagner, C. Inorg. Chim. Acta 2003, 350, 399-406.

(17) Gong, J. K.; Fanwick, P. E.; Kubiaks, C. P. J. Chem. Soc., Chem. Commun. 1990, 1190-1191.

(18) Heyke, O.; Hiller, W.; Lorenz, I. P. Chem. Ber. 1991, 124, 2217-2222.

(19) Karet, G. B.; Stern, C. L.; Norton, D. M.; Shriver, D. F. J. Am. Chem. Soc. $1993,115,9979-9985$.

(20) Pandey, K. K. Prog. Inorg. Chem. 1992, 40, 445-505.

(21) Schenk, W. A. Angew. Chem., Int. Ed. Engl. 1987, 26, 98-109.

(22) Ryan, R. R.; Kubas, G. J.; Moody, D. C.; Eller, P. G. Struct. Bonding (Berlin) 1981, 46, 47-100.

(23) Herting, D. L.; Sloan, C. P.; Cabral, A. W.; Krueger, J. H. Inorg. Chem. 2002, 17, 1649-154.

(24) Allred, B. R. T. M.S Thesis Formation of the Thiolate and ThioperoxideBridged Dimolybdenum Dimers. 1996.

(25) Tuong, C. M. M.S Thesis Isomerization, Reactivity, and Structural Study of a Thioperoxide-Bridge Dimolybdenum(V) Dimer. 2004.

(26) Tuong, C. M.; Hammons, W. K.; Howarth, A. L.; Lutz, K. E.; Maduvu, A. D.; Haysley, L. B.; Allred, B. R.; Hoyt, L. K.; Mashuta, M. S.; Noble, M. E. 
Inorg. Chem. 2009, 48, 5027-5030.

(27) Bondi, A. J. Phys. Chem. 1964, 68, 441-451.

(28) Lizano, A. C.; Munchhof, M. G.; Haub, E. K.; Noble, M. E. J. Am. Chem. Soc. 1991, 113, 9204-9210.

(29) Noble, M. E. Inorg. Chem. 1986, 25, 3311-3317.

(30) Haub, E. K.; Richardson, J. F.; Noble, M. E. Inorg. Chem. 1992, 31, 49264932.

(31) Koffi-Sokpa, E. I.; Calfee, D. T.; Allred, B. R. T.; Davis, J. L.; Haub, E. K.; Rich, A. K.; Porter, R. A.; Mashuta, M. S.; Richardson, J. F.; Noble, M. E. Inorg. Chem. 1999, 38, 802-813.

(32) Wang, R. Ph.D Thesis, Synthesis, Reactivity and Structural Studies of a Dimolybdenum(V)Complex with Sulfur Oxides, Disulfide and Oxide Bridges. 1997.

(33) Lee, Q. J. Ph.D Thesis, Reactivity and Structural Studies of a Dimolybdenum(v)-Sulfur Bridged Dimer. 1996.

(34) Noble, M. E.; Williams, D. E. Inorg. Chem. 1988, 27, 749-752.

(35) Ulic, S.E.; Kosma, A.; Della Vedova, C.O.; Willner, H.; Oberhammer, H. J. Phys. Chem. A 2006, 110, 10201-10205. Ulic, S.E.; Kosma, A.; Leibold, C.; Della Vedova, C.O.; Willner, H.; Oberhammer, H. J. Phys. Chem. A 2005, 109, 3739-3744.

(36) Buschmann, J.; Luger, P.; Koritsanszky, T.; Schmidt, H.; Steudel, H.; Steudel, R. J. Phys. Chem. 1992, 96, 9243-9250.

(37) Noble, M.E.; Inorg. Chem., 1987, 26, 877-882. 


\section{APPENDIX}

\section{LIST OF ABBREVIATIONS}

\begin{tabular}{|c|c|}
\hline $\mathrm{Me}$ & Methyl \\
\hline Et & Ethyl \\
\hline $\mathrm{Bn}$ & Benzyl \\
\hline To & $p$-tolyl \\
\hline $\mathrm{Ph}$ & phenyl \\
\hline Dppe & 1,2-bis(diphenylphosphino) ethane \\
\hline $\mathrm{PPN}^{+}$ & $\mathrm{Ph}_{3} \mathrm{PNPPh}_{3}^{+}$ \\
\hline MPA & $(\mathrm{R})-(-)-\alpha-$ methoxyphenylacetic acid \\
\hline$\left[\mathrm{Mo}_{4}\right]$ & {$\left[\mathrm{Mo}(\mathrm{NTo})\left(\mathrm{S}_{2} \mathrm{P}(\mathrm{OEt})_{2}\right)(\mu-\mathrm{S})\right]_{4}$} \\
\hline $\mathrm{BnS}\left\{\mathrm{Mo}_{2}\right\} \mathrm{SO}$ & $\mathrm{Mo}_{2}(\mathrm{NTo})_{2}\left(\mathrm{~S}_{2} \mathrm{P}(\mathrm{OEt})_{2}\right)_{2}\left(\mu-\mathrm{O}_{2} \mathrm{CR}\right)(\mu-\mathrm{SBn})(\mu-\mathrm{SO})$ \\
\hline $\mathrm{S}\left\{\mathrm{Mo}_{2}\right\} \mathrm{SOBn}$ & $\mathrm{Mo}_{2}(\mathrm{NTO})_{2}\left(\mathrm{~S}_{2} \mathrm{P}(\mathrm{OEt})_{2}\right)_{2}\left(\mu-\mathrm{O}_{2} \mathrm{CCH}_{3}\right)(\mu-\mathrm{S})(\mu-\mathrm{SOBn})$ \\
\hline$\left[\mathrm{S}\left\{\mathrm{SMO}_{2}\right\} \mathrm{SS}\left\{\mathrm{Mo}_{2}\right\} \mathrm{SOBn}\right]^{+}$ & {$\left[\mathrm{Mo}_{4}(\mathrm{NTo})_{4}\left(\mathrm{~S}_{2} \mathrm{P}(\mathrm{OEt})_{2}\right)_{4} \mathrm{~S}_{3}\left(\mathrm{O}_{2} \mathrm{CMe}\right)_{2}(\mathrm{SOBn})\right]^{+}$} \\
\hline
\end{tabular}




\section{CURRICULUM VITAE}

Department of Chemistry

University of Louisville

2320 South Brook Street

Louisville, KY 40292

Telephone: (502) 295-3006

Email: admadh01@1ouisville.edu
Home address:

777 Theodore Bunnet Ct 5

Louisville, KY 40217

Telephone: (502) 295-3006

Email:admadhuvu@yahoo.co.uk

\section{Education}

National University of Science and Technology, Bulawayo, Zimbabwe

BSc (honors) in Applied Chemistry (Oct. 2004)

Research Advisor: Prof. M. Bhalla

Thesis Title: 'Effluent Analysis of Brewery Waste Water'

\section{Scholarship and Awards}

- College Undergraduate Award, National University of Science and Technology, Bulawayo, for the year 2000-2001.

- Unilever South East Africa/ National University of Science and Technology for the years 2003-2004

- Bright ideas Award for month of August 2005 Delta Beverages.

\section{$\underline{\text { Research Experience }}$}

May 2007-present Department of Chemistry,

University of Louisville Graduate Chemistry Student

Advisor: Prof. Mark Noble 
Publication: 'Alkylation of a Dimolybdenum SO Bridge, Subsequent,
Reactions and Characterization of the Thioperoxide Bridge'

National University of Science and Technology

Undergraduate Student Aug.2000-July 2004 Department of

Chemistry.

Advisor: Professor Prof. M. Bhalla

Project Title: 'Effluent Analysis of Brewery Waste Water'

Aug. 2004-Dec.2006 Quality Assurance Department,

Delta Beverages, Bulawayo, Zimbabwe

Research Assistant

Advisor: David Nyika

'Effects of Hops on the beer shelf life'

\section{Teaching Experience}

Jan. 2007-Present Graduate Teaching Assistant

Department of Chemistry, University of Louisville

June. 2010

Adjunct Instructor -Chemistry

St. Catharine College, Spring Field, Kentucky. 